

\section{The Building Science Series}

The Building Sciener Series disseminates'technical information develuped at the National Bureau of Standards on building miterials, componcnts, systems, and whole structures. The Series presents research results, test methods. and performance criteria related to the structural and environmental functions and the durability and safety characteristics of building clements and systems.

These publications, similar in style and content to the NBS Building Materials and Structures Reports (1938-59), are directed toward the manufacturing, design, construction, and research segments of the building industry, standaris organizations, and officials responsible for building cades.

The matcrial for this Series originates principally in the Center for Building Technology of the NBS Institute for Applicd Technology. The publications are divided into three general groups: Building Systems and Processes; Health, Safcty and Comfort; and Structures and Materials. For further information regarding these publications please contact the Scientific and Professional Liaison Section, Center for Building Technology, Institute for Applied Technology, National Bureau of Standards, Washington, D.C. 20234. 


\section{Pre-Design Analysis of Energy Conservation Options for a Multi-Story Demonstration Office Building}

Tamami Kusuda, James E. Hill, Stanley T. Liu, James P. Barnett, and John W. Bean

Institute for Applied Technology

National Bureau of Standards

Washington, D.C. 20234

Sponsored by

General Services Administration

18 th and F Streets. N.W.

Washington, D.C. 20405

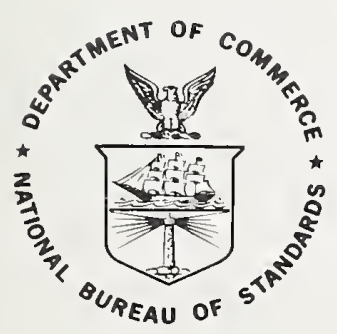

U.S. DEPARTMENT OF COMMERCE, Rogers C. B. Morton, Secrełary James A. Baker, III, Under Secretary

Dr. Betsy Ancker-Johnson, Assistant Secretary for Science and Technology NATIONAL BUREAU OF STANDARDS, Ernest Ambler, Acting Director Issued November 1975 


\section{Library of Congress Cataloging in Publication Data}

Main entry under title:

Pre-Design Analysis of Energy Conservation Options for a MultiStory Demonstration Office Building.

(NBS Building Science series; 78)

Bibliography: p.

Supt. of Docs. No.: C $13.29: 2 / 78$

1. Office Buildings. 2. Tall Buildings. 3. Energy Conservation. 4. Environmental Engineering (Buildings) I. Kusuda, Tamami. II. United States. General Services Administration. III. Series: United States. National Bureau of Standards. Building Science Series; 78.

TA435.U58 No. 78 [TH4311] 690'.08s [696] 75-619306

\section{National Bureau of Standards Building Science Series 78}

Nat. Bur. Stand. (U.S.), Bldg. Sci. Ser. 78, 64 pages (Nov. 1975)

CODEN: BSSNBV 
TABLE OF CONTENTS

Page

1. Introduction . . . . . . . . . . . . . . . . . . . . . . . . . . 1

2. Weather and Geographical Data for Manchester, New Hampshire . . . . . . . 2

3. NBSLD - A Computer Program for Design Analysis . . . . . . . . . . . . . . . 3

4. Preliminary Design Analysis . . . . . . . . . . . . . . . . . . . . 3

5. Building Zone Calculations . . . . . . . . . . . . . . . . . . . . 8

6. Miscellaneous Design Day Calculations . . . . . . . . . . . . . . . . 11

7. Analysis of the Final Building Design . . . . . . . . . . . . . . . . . 12

8. Summary . . . . . . . . . . . . . . . . . . . . . . . . 15

9. References . . . . . . . . . . . . . . . . . . . . . . 15

Figures . . . . . . . . . . . . . . . . . . . . . . . . . . . . 16

Tables . . . . . . . . . . . . . . . . . . . . . . . . . . 48 

Pre-Design Analysis of Energy Conservation Options

for a Multi-Story Demonstration Office Building

Tamami Kusuda, James E. Hill, Stanley T. Liu, James P. Barnett, and John W. Bean

Thermal Engineering Section, Building Environment Division

Center for Building Technology

\section{A BSTRACT}

The design phase of the GSA-Manchester Building included extensive analysis of the building design and operation to determine the potential for energy conservation. Described in this report are highlights and a summary of the calculations performed during the design phase. The analysis included a study of the effect of the exterior shell, ventilation rate, lighting and occupancy levels, room temperature controls, and nighttime flushing of the building using outdoor air on the predicted yearly energy consumption of the building.

Key words: Building design; building energy analysis; energy conservation options; heating and cooling load calculation; energy design optimization.

\section{Introduction}

During the latter part of 1972, Commissioner Arthur Sampson of the General Services Administration (GSA) designated a Federal Office Building to be built in Manchester, New Hampshire, as an energy conservation demonstration project. The purpose of this project is to (a) dramatize the firm commitment of the Federal Government to the conservation of energy in the design, construction and operation of government buildings; (b) provide a laboratory for the installation of both recognized and innovative energy conservation technologies (with a goal toward obtaining at least $20 \%$ energy saving as compared to other comparable buildings); and (c) inspire others in the building industry to pursue energy conservation as a goal.

In January of 1973, the firm of Dubin, Minde11, Bloome, and Associates, consulting engineers of New York City, was awarded a contract to develop a set of recommendations for the design and construction of the Manchester Building. The National Bureau of Standards (NBS), at the request of the General Services Administration, collaborated with the Dubin firm in evaluating the effect of various building parameters on the building's annual energy consumption. The building energy analyses described in this report were performed by the use of the National Bureau of Standards heating and cooling load calculation program, NBSLD.

Based upon the resulting recommendations, the firm of Isaak and Isaak, architects of Manchester, New Hampshire, was awarded a contract to prepare working drawings and specifications for the building. The mechanical/electrical design, which includes the design of the heating, ventilating and air-conditioning systems, was in turn subcontracted to the R. D. Kimball Company of Cambridge, Massachusetts. The National Bureau of Standards assisted the R. D. Kimball Company in sizing various components of the heating and cooling system. GSA also designated NBS to be responsible for designing and operating the instrumentation system which will allow the determination of energy consumption as well as other pertinent performance characteristics of the building and its systems. In this connection, NBS drafted specifications to be used for purchasing and installing a computerized data acquisition system. This latter task will be covered in a separate report. 
Manchester, New Hampshire is located along the Merrimack River, $97 \mathrm{~km}$ (60 miles) north of Boston, Massachusetts at an altitude of $89 \mathrm{~m}(290 \mathrm{ft})$ above sea level. As shown in Figure 1, it is situated approximately at the geographical center of New England. At one time it was one of the largest mill and shoe manufacturing towns in New England. Its population, although less now than in the heyday of the textile mill activities, still exceeds haif a million. The surrounding countryside is hilly and dotted with many lakes and woods. Mount Washington is approximately $140 \mathrm{~km}$ (90 miles) north of the town. The building site for the particular government building under study is the center of the downtown section and surrounded by several buildings of 2 to 3 stories, as well as an 8 story "high-rise" directly to the south.

Because hour-by-hour weather data were not available for Manchester, climatological data for a nearby town, Concord ( $32 \mathrm{~km}$ (20 miles) north of Manchester) were used for the building energy analysis. The exact location of Concord is 43 degrees north latitude, 71 degrees, 30 minutes longitude, and at an elevation of $104 \mathrm{~m}$ (342 ft), which is not significantly different from Manchester. Local climatological data from the Environmental Data Services (NOAA) [1]* were used to plot the 30 year (1931-1960) norm values for month1y average temperature as well, as the extremes (highest and lowest) of the monthly averages for the 30 years (See Figure 2). Other annual normal values of interest were:

$\begin{array}{ll}\text { Average Rainfall } & 0.986 \mathrm{~m} \text { (38.3 in.) } \\ \text { Average Snowfa1l } & 1.63 \mathrm{~m}(64.1 \mathrm{in}) \\ \text { Average Wind Speed, Yearly } & 3.4 \mathrm{~m} / \mathrm{s}(7.6 \mathrm{mph}) \\ \text { Average Wind Speed, Summer } & 2.9 \mathrm{~m} / \mathrm{s}(6.5 \mathrm{mph}) \\ \text { Average Wind Speed, Winter } & 3.7 \mathrm{~m} / \mathrm{s}(8.3 \mathrm{mph}) \\ \text { Prevailing Wind Direction, Summer } & \mathrm{NW} \\ \text { Prevailing Wind Direction, Winter } & \mathrm{NW} \\ \text { Average \% of Possible Sunshine } & 54 \% \\ \text { Average Sky Cover } & 6.1^{* \circ:}\end{array}$

The ASHRAE Handbook of Fundamentals [2] lists the following percentile values used for equipment design for both Manchester and Concord, New Hampshire

\begin{tabular}{|c|c|c|c|c|}
\hline & & & & \\
\hline & & & & $971 / 2 \%$ \\
\hline Concord & & -25 & $\left.13^{\circ} \mathrm{F}\right)$ & $-22^{\circ} \mathrm{C}\left(-7^{\circ} \mathrm{F}\right)$ \\
\hline Manchester & & -21 & $\left.5^{\circ} \mathrm{F}\right)$ & $-17^{\circ} \mathrm{C} \quad\left(1^{\circ} \mathrm{F}\right)$ \\
\hline & & & & \\
\hline & $1 \%$ & & $21 / 2 \%$ & $5 \%$ \\
\hline Concord & $33^{\circ} \mathrm{C}(91$ & ${ }^{\circ} \mathrm{F}$ ) & $31{ }^{\circ} \mathrm{C}\left(88^{\circ} \mathrm{F}\right)$ & $29^{\circ} \mathrm{C}\left(85^{\circ} \mathrm{F}\right)$ \\
\hline Manchester & $33^{\circ} \mathrm{C} \quad(92$ & $\left.{ }^{\circ} \mathrm{F}\right)$ & $32{ }^{\circ} \mathrm{C}\left(89^{\circ} \mathrm{F}\right)$ & $30^{\circ} \mathrm{C}\left(86^{\circ} \mathrm{F}\right)$ \\
\hline
\end{tabular}

* Figures in brackets indicate the literature References listed in Section 10. ** 0 if a completely clear sky and 10 is completely cloudy. 
$99 \%$ and $971 / 2 \%$ winter percentile values mean that approximately 30 and 72 hourly temperatures, respectively, during the winter were lower than these values. Similarly, the $1 \%$, $21 / 2 \%$, and $5 \%$ summer percentile values mean that approximately 30,72 , and 144 hourly temperatures, respectively, during the summer were higher than the specified values. It is rather surprising that the ASHRAE $99 \%$ and $971 / 2 \%$ percentile data for Concord are $4{ }^{\circ} \mathrm{C}\left(8^{\circ} \mathrm{F}\right)$ lower than for Manchester.

By using the proposed procedure for the ASHRAE Task Group on Energy Requirements [3], the year chosen for the hour-by-hour building energy analysis was 1962. Figure 2 shows that the monthly average temperatures for this particular year were very close to the thirty year norm values given in the local climatological data. Several other methods presently being considered by the ASHRAE Task Group for selecting TYWD (Test Year Weather Dața) were used and all the methods yielded the same year.

Figure 3 is a hourly plot of dry-bulb temperature and humidity ratio for 1962 from the Concord weather tape. Coincident frequency of temperature and humidity for this year is presented on the psychrometric chart in Figure 4 in the form of a three-dimensional isometric

plot. A two-dimensional equal frequency contour map of the same data is shown in Figure 5. By observing Figure 4, one can see where the majority of the peaks on the psychrometric plots lie. The higher peaks are predominant at temperattures lower than $10^{\circ} \mathrm{C}\left(50^{\circ} \mathrm{F}\right)$. The ASHRAE $99 \%, 97.5 \%, 5 \%$, and $1 \%$ design values are indicated in the figure and as can be seen, they bracket the higher and lower ends of the dry and wet-bulb conditions that occur.

\section{NBSLD - A Computer Program for Design Analysis}

In order to determine heating and cooling loads as well as the temperature and humidity in non-air-conditioned spaces responding to randomly fluctuating outdoor climatic conditions, a computer program to calculate hourly building heat gain and heat loss has been developed at the National Bureau of Standards [4,5,6]. The program is called "NBSLD" and consists of various subroutines for calculating heat gains, which are similar to those recommended by the ASHRAE Task Group on Energy Requirements [7]. One major extension of the program beyond that recommended by the ASHRAE Task Group is a routine called RMTMP, which solves for room air temperature or the load felt by the room air through the use of a series of simultaneous heat balance equations. The details of this routine are given in reference [6].

This particular computer simulation has been verified by experimental work on two separate research projects at NBS [8,9]. In the first study [8], a small $6.1 \mathrm{~m}(20 \mathrm{ft})$ by $6.1 \mathrm{~m}$ $(20 \mathrm{ft}$ ) by $3.1 \mathrm{~m}(10 \mathrm{ft})$ masonry building was built within a large environmental chamber where the temperatures could be adjusted and controlled from $-46{ }^{\circ} \mathrm{C}\left(-50{ }^{\circ} \mathrm{F}\right)$ to $+66^{\circ} \mathrm{C}$ $\left(+150^{\circ} \mathrm{F}\right)$. The building was subjected to typical diurnal temperature fluctuations and the indoor temperature and/or heating load was both measured and predicted by NBSLD. In the latter study [9], a more realistic living unit was used; a four-bedroom, lightweight house that was completely furnished and had the activity of a six member family simulated within. This house was also tested inside the environmental chamber where the outdoor conditions were controlled and precisely known.

\section{Preliminary Design Analysis}

The first series of energy calculations on the Manchester Building began by considering a building that would be built according to "Typical Design Practice", in the New England area. The building data for this building were provided by Dubin, Mindell, Bloome, and Associates and was as follows:

$$
\begin{aligned}
& \text { Gross floor area }-\frac{11,000 \mathrm{~m}^{2}\left(126,000 \mathrm{ft}^{2}\right) \text { office }}{3900 \mathrm{~m}^{2}\left(42,000 \mathrm{ft}^{2}\right) \text { underground garage }} \\
& 6 \text { stories - } 1,950 \mathrm{~m}^{2}\left(21,000 \mathrm{ft}^{2}\right) / \mathrm{floor}
\end{aligned}
$$


Aspect ratio - $2: 1$, long axis running $\mathrm{N}-\mathrm{S}$

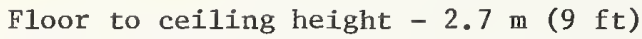

Floor to floor distance $-4 \mathrm{~m}$ (13 ft)

Roof $-0.1 \mathrm{~m}$ ( 4 in.) of H.W. concrete* with insulation on the top, U winter $=1.13 \mathrm{~W} /$ $\left(\mathrm{m}^{2} \cdot{ }^{\circ} \mathrm{K}\right)\left(0.20 \mathrm{Btu} /\left(\mathrm{h} \cdot \mathrm{ft}^{2} \cdot{ }^{\circ} \mathrm{F}\right)\right) * t$

Walls - $0.15 \mathrm{~m}$ ( 6 in.) of H.W. concrete* with insulation on the inside, U $1.70 \mathrm{~W} /\left(\mathrm{m}^{2} \cdot{ }^{\circ} \mathrm{K}\right)\left(0.30 \mathrm{Btu} /\left(\mathrm{h} \cdot \mathrm{ft}^{2} \cdot{ }^{\circ} \mathrm{F}\right)\right) * *$, absorptivity to solatinter $\mathrm{ration}=0.9$

Floor above garage - $0.15 \mathrm{~m}$ (6 in.) of H.W. concrete* with insulation on the bottom, $\mathrm{U}_{\text {winter }}=1.42 \mathrm{~W} /\left(\mathrm{m}^{2} \cdot{ }^{\circ} \mathrm{K}\right)\left(0.25 \mathrm{Btu} /\left(\mathrm{h} \cdot \mathrm{ft}^{2} \cdot{ }^{\circ} \mathrm{F}\right)\right) * *$

Windows - single pane, shading coefficient $=0.50$ (inside shading), no outdoor shading, $\mathrm{U}_{\text {winter }}=6.41 \mathrm{~W} /\left(\mathrm{m}^{2} \cdot{ }^{\circ} \mathrm{K}\right)\left(1.13 \mathrm{Btu} /\left(\mathrm{h} \cdot \mathrm{ft}^{2} \cdot{ }^{\circ} \mathrm{F}\right)\right) * *$

Glass area $50 \%$ of the exposed room wall area on all sides. (This corresponds to approximately $1 / 3$ of the total exterior wall area).

Garage temperature equal to outdoor air temperature at al1 times

Lighting on 8:00 a.m. to $6: 00 \mathrm{p} . \mathrm{m}$. weekdays (except holidays), $38 \mathrm{~W} / \mathrm{m}^{2}\left(3.5 \mathrm{~W} / \mathrm{ft}^{2}\right.$ ) of floor area for $75 \%$ of the floor, $11.8 \mathrm{~W} / \mathrm{m}^{2}\left(1 \mathrm{~W} / \mathrm{ft}^{2}\right)$ of floor area for $25 \%$ of the floor area

Occupancy 600 people, 8:00 a.m. to 6:00 p.m. weekdays (except for holidays)

Office equipment $5.4 \mathrm{~W} / \mathrm{m}^{2}\left(1 / 2 \mathrm{~W} / \mathrm{ft}^{2}\right)$ of floor area for $75 \%$ of the floor area, 8:00 a.m. to 6:00 p.m. weekdays (except holidays)

Ventilation air $-7.1 \mathrm{~m}^{3} / \mathrm{s}(15,000 \mathrm{cfm})$ of outdoor air, 8:00 a.m. to 6:00 p.m. (except holidays)

Infiltration air - $1 / 4$ air change per hour, constant

Calculations based on the following indoor conditions:

$70^{\circ} \mathrm{F}, 30 \% \mathrm{RH}$ - October through May, 8:00 a.m. to 6:00 p.m. during weekdays (except holidays)

$60^{\circ} \mathrm{F}, 42 \% \mathrm{RH}$ - (humidity ratio the same as during the occupied period) - October through May, 6:00 p.m. to 8:00 a.m. during weekdays (except holidays) and 24 hours on weekends and holidays

$75^{\circ} \mathrm{F}, 50 \% \mathrm{RH}$ - June through September, 8:00 a.m. to 6:00 p.m. during weekdays (except holidays)

No cooling allowed (and hence no cooling load was calculated) during non-occupancy hours for the entire year

No heating allowed (and hence no heating load was calculated) for the months of June through September

* Concrete having a density of approximately $2200 \mathrm{~kg} / \mathrm{m}^{3}$ (140 $1 \mathrm{~b} / \mathrm{ft}^{3}$ )

** These values were adjusted for actual wind velocity every hour 
Al1 calculations based on a 1 room, 1 zone model. for the building

For purposes of reporting the energy requirements for the building, the following additional assumptions were made:

office ventilation fans require $37,000 \mathrm{~W}$ during occupancy hours.

Garage ventilation fans require $27,000 \mathrm{~W}$ during occupancy hours.

Building hot water requirements are $29,000 \mathrm{~W}(100.000 \mathrm{Btu} / \mathrm{h})$ during occupancy hours.

Chilled and hot water pumps consume 27,000 $\mathrm{W}$ during occupancy hours, June through September, and require $27,000 \mathrm{~W}$ for a11 24 hours, October through May.

Cooling tower and miscellaneous electrical equipment required 45,000 W (60 hp) during occupancy hours.

(Energy requirements for heating and supplying hot water $)=\left(\frac{\text { Load }}{0.60}\right)$

(Energy requirements for cooling) $=\left(\frac{\text { Load }}{2.5}\right)$

(Energy requirements for lights, fans, pumps, office equipment, miscellaneous equipment, and cooling tower) $=$ (Load)

The above equations imply a seasonal heating efficiency of $60 \%$ and a seasonal cop* for cooling of 2.5 .

Once this "Design Practice Building" was defined, its yearly energy consumption for the year 1962 was predicted. A summary plot of the data is shown in Figure 7 . One should note the relatively large percentage of the total energy consumed that goes for lighting as well as for driving the pumps and fans for the heating and cooling systems.

A special routine was written and added to NBSLD to enable the results to be printed out in a special format. For each month of the year and for the year as a whole, two tables of data were obtained, one for details of the heating and cooling loads and one for energy requirements.

Table 1 is a sample of the heating and cooling load print out. The table is divided into three parts. The upper part gives the total heating load and total cooling load (maximum, average, total for the month per $\mathrm{ft}^{2}$ of gross floor area, and total for the month). The middle part gives all components of heat gain that occur during the month and consequently contribute to the cooling load. The column giving the monthly total of each component per $\mathrm{ft}^{2}$ is per $\mathrm{ft}^{2}$ of area for that component. For example, the monthly total per $\mathrm{ft}^{2}$ of heat gain through the south windows is in Btu/ft ${ }^{2}$ of south-facing glass. A monthly percentage is given for each parameter.

$\begin{aligned} & \text { monthly percentage } \\ & \text { for each component }\end{aligned}=\frac{\text { total monthly gain for each component }}{\text { total monthly gain for the building }} \times 100$

The hourly maximum and hourly average values of each parameter were based on every hour in the month (i.e., the hourly maximum dry-bulb temperature is the maximum value that occurred any time during the month). The lower part of the table shows a similar result for all heat loss components that contribute to the heating load.

Table 2 is a sample of the energy requirements print out. All quantities are expressed in terms of Btu of energy at the building and various efficiencies or conversion factors were assumed as noted on the previous pages.

* COP is defined as quantity of cooling output from the machine divided by the energy input to the machine. 
Following the analysis on the "Design Practice Building", individual design changes were made and the calculations repeated to determine the change in the predicted annual energy consumption and peak heating and cooling loads.' Taking the initial computer run as Run No. 1, the following lisist describes the subsequent calculations:

Run 2 The same as Run 1 except that U-values for the wall were $0.57 \mathrm{~W} /\left(\mathrm{m}^{2} \cdot{ }^{\circ} \mathrm{K}\right)$. $\left(0.1 \mathrm{Btu} /\left(\mathrm{h} \cdot \mathrm{ft}^{2} \cdot{ }^{\circ} \mathrm{F}\right)\right)$.

Run 3 The same as Run 1 except that U-values for the walls were $0.34 \mathrm{~W} /\left(\mathrm{m}^{2} \cdot{ }^{\circ} \mathrm{K}\right)$ $\left(0.06 \mathrm{Btu} /\left(\mathrm{h} \cdot \mathrm{ft}^{2} \cdot{ }^{\circ} \mathrm{F}\right)\right)$.

Run 4 The same as Run 1 except that the U-value for the floor was $0.57 \mathrm{~W} /\left(\mathrm{m}^{2} \cdot{ }^{\circ} \mathrm{K}\right)$ $\left(0.1 \mathrm{Btu} /\left(\mathrm{h} \cdot \mathrm{ft}^{2} \cdot{ }^{\circ} \mathrm{F}\right)\right)$.

Run 5 The same as Run 1 except that the U-value for the floor was $0.34 \mathrm{~W} /\left(\mathrm{m}^{2} \cdot{ }^{\circ} \mathrm{K}\right)$ $\left(0.06 \mathrm{Btu} /\left(\mathrm{h} \cdot \mathrm{ft}^{2} \cdot{ }^{\circ} \mathrm{F}\right)\right)$.

Run 6 The same as Run 1 except that the U-value for the roof was $0.57 \mathrm{~W} /\left(\mathrm{m}^{2} \cdot{ }^{\circ} \mathrm{K}\right)$ $\left(0.1 \mathrm{Btu} /\left(\mathrm{h} \cdot \mathrm{ft}^{2} \cdot{ }^{\circ} \mathrm{F}\right)\right)$.

Run 7 The same as Run 1 except that the U-value for the roof was $0.34 \mathrm{~W} /\left(\mathrm{m}^{2} \cdot{ }^{\circ} \mathrm{K}\right)$ $\left(0.06 \mathrm{Btu} /\left(\mathrm{h} \cdot \mathrm{ft}^{2} \cdot{ }^{\circ} \mathrm{F}\right)\right)$.

Run 8 The same as Run 1 except that the windows were double glazed.

Run 9 The same as Run 1 except that the windows were triple glazed.

Run 10 The same as Run 1 except that a shading coefficient of 0.75 was used instead of 0.5 .

Run 11 The same as Run 1 except that a shading coefficient of 1.0 was used instead of 0.5 .

Run 12 The same as Run 1 except that the window to wall area ratio was reduced from $50 \%$ to $30 \%$.

Run 13 The same as Run 1 except that the window to wall area ratio was reduced from $50 \%$ to $10 \%$.

Run 14 The same as Run 1 except that the number of floors was changed from 6 to 8 while keeping the total floor area constant.

Run 15 The same as Run 1 except that the number of floors was changed from 6 to 10 while keeping the total floor area constant.

Run 16 The same as Run 1 except that the aspect ratio was changed from 2:1 to 1:1 while keeping the total floor area constant.

Run 17 The same as Run 16 except that the building was rotated by 45 degrees.

Run 18 The same as Run 1 except that the building was rotated by 90 degrees.

Run 19 The same as Run 1 except that the insulation position in the roof and floor was reversed ( $p$ laced outside of the concrete-masonry unit).

Run 20 The same as Run 1 except the following:

a. Double glazed windows

b. Glass to wall area: $10 \%$

c. Aspect ratio: $1: 1$

d. All U-values were $0.34 \mathrm{~W} /\left(\mathrm{m}^{2} \cdot{ }^{\circ} \mathrm{K}\right)\left(0.06 \mathrm{Btu} /\left(\mathrm{h} \cdot \mathrm{ft}^{2} \cdot{ }^{\circ} \mathrm{F}\right)\right)$

Run 21 The same as Run 20 except that the aspect ratio was $2: 1$. 
Run 22 The same as Run 21 except that "TWINDOW"* (U = 2.3 W/ (m $\left.{ }^{2} \cdot{ }^{\circ} \mathrm{K}\right)(0.41 \mathrm{Btu} /(\mathrm{h} \cdot$ $\left.\mathrm{ft}^{2} \cdot{ }^{\circ} \mathrm{F}\right)$ ) and shading coefficient $=0.22$ ) was used.

Run 23 The same as Run 22 except as follows:

a. Glass to wall area ratio: $331 / 3 \%$

b. U of glass $=0.57 \mathrm{~W} /\left(\mathrm{m}^{2} \cdot{ }^{\circ} \mathrm{K}\right)\left(0.1 \mathrm{Btu} /\left(\mathrm{h} \cdot \mathrm{ft}^{2} \cdot{ }^{\circ} \mathrm{B}\right)\right)$ during the unoccupied hours.

c. No direct solar radiation was allowed to fall on the windows at any time during the year.

Run 24 The same as Run 22 except that the glass to wall area ratio was increased to $331 / 3 \%$ and a window overhang was included to exclude $100 \%$ of the direct solar radiation during August.

Run 25 The same as Run 24 except that the August direct solar radiation exclusion was only $80 \%$.

Table 3 summarizes the results of these 25 computer runs.

Although this series of calculations showed that it was possible to design a building with a 33 percent reduction in yearly energy requirements compared to the initial building one should not conclude that the savings that GSA originally announced as a goal can now automatically be realized. Throughout this analysis, constant efficiencies for the installed equipment was assumed as noted previously. Depending on the type of system and controls that are installed, the above figures could be drastically altered.

In addition to these 25 runs using NBSLD, three separate calculations were made to determine the natural air change of the building by using a special computer program developed by the National Research Council of Canada [10]. This program solves many simultaneous equations that describe the pressure differences across the exterior walls, floors, doors, and interior separation of a given building. The program essentially models the building in one dimension and requires assumed air velocity and temperature profiles on the outside of the building as input. Calculations were done on the building of Run 1 using this program and the assumptions in the calculations are identified as follows:

Floors: 6

Floor/Floor Height: $4 \mathrm{~m}(13 \mathrm{ft})$

Glass: $50 \%$ of wall area, $1.8 \mathrm{~m} \times 1.8 \mathrm{~m}$ ( $6 \mathrm{ft} \times 6 \mathrm{ft})$

Entry Doors: One revolving $1.8 \mathrm{~m} \mathrm{dia.} \mathrm{(6} \mathrm{ft),} \mathrm{two} \mathrm{swinging} 0.9 \mathrm{~m} \times 2.1 \mathrm{~m}$ ( $3 \mathrm{ft} \times 7 \mathrm{ft}$ )

Elevators: $3 ; 1.8 \mathrm{~m} \times 2.1 \mathrm{~m}$ door $(6 \mathrm{ft} \times 7 \mathrm{ft}), 0.15 \mathrm{~m} \times 0.23 \mathrm{~m}$ vent on top (6 in. by 9 in.)

Staircases: 2 ; $0.9 \mathrm{~m} \times 2.1 \mathrm{~m}$ door ( $3 \mathrm{ft} \times 7 \mathrm{ft}$ )

Crack Areas: Exterior wa11, window, and door; $0.19 \mathrm{~m}^{2}\left(2.05 \mathrm{ft}^{2}\right)$ lst floor, $0.14 \mathrm{~m}^{2}$ $\left(1.50 \mathrm{ft}^{2}\right)$ 2nd and up

Elevator (each): $0.09 \mathrm{~m}^{2}\left(1.0 \mathrm{ft}^{2}\right)$

Staircase (each): $0.046 \mathrm{~m}^{2}\left(0.50 \mathrm{ft}^{2}\right)$

Between Floors: $0.57 \mathrm{~m}^{2}\left(6.0 \mathrm{ft}^{2}\right)\left(1,950 \mathrm{~m}^{2}\left(21,000 \mathrm{ft}^{2}\right)\right.$ of floor area)

Elevator Vent (each): $0.348 \mathrm{~m}^{2}\left(0.375 \mathrm{ft}^{2}\right)$

* Identification of commercial products does not imply recommendation or endorsement by the National Bureau of Standards. 
Wind Speed: $6.7 \mathrm{~m} / \mathrm{s}$ (15 mph)

Outside Temperature: $-18{ }^{\circ} \mathrm{C}\left(0^{\circ} \mathrm{F}\right)$

Inside Temperature: $21{ }^{\circ} \mathrm{C}\left(70^{\circ} \mathrm{F}\right)$

The results of the calculations were as follows:

$\begin{array}{cccc} & \begin{array}{c}\text { Assumption } \\ 1\end{array} & \begin{array}{c}\text { Assumption } \\ 2\end{array} & \begin{array}{c}\text { Assumption } \\ 3\end{array} \\ \text { Pressurization Flow } & 0 \mathrm{~m}^{3} / \mathrm{s}(0 \mathrm{cfm}) & \begin{array}{l}0.12 \mathrm{~m}^{3} / \mathrm{s}(250 \\ \mathrm{cfm}) / \mathrm{floor}\end{array} & \begin{array}{l}0.24 \mathrm{~m}^{3} / \mathrm{s}(500 \\ \mathrm{cfm}) / \mathrm{floor}\end{array} \\ \begin{array}{c}\text { Total Infiltration, } \\ \mathrm{m}^{3} / \mathrm{s} \mathrm{(cfm)}\end{array} & \begin{array}{c}1.44 / \mathrm{bldg} . \\ (3,050)\end{array} & \begin{array}{c}1.14 / \mathrm{bldg}, \\ (2,420)\end{array} & \begin{array}{c}0.774 / \mathrm{bldg} \\ (1,640)\end{array} \\ \text { Air Change/Hr } & .16=1 / 6 & .128=1 / 8 & .087=1 / 12\end{array}$

Figure 8 depicts the hourly air change rate of the building plotted against the difference between the supply air rate and the exhaust air rate in the mechanical ventilation system (here called the net air loss). The figure shows that as the net air loss increases, the natural air infiltration decreases because of the increased pressurization of the building. The infiltration becomes zero, or the building becomes completely pressurized, when the supply air rate exceeds the exhaust air rate by approximately $2.03 \mathrm{~m}^{3} / \mathrm{s}(43,000 \mathrm{cfm})$.

\section{Building Zone Calculations}

Following the preliminary analysis above, the building was modeled in more detail by breaking each floor into five zones, $4.6 \mathrm{~m}$ (15 ft) deep zones on the north, west, south, and east sides of the building with the remaining area on each floor in a core zone. The energy consumption in each zone could then be predicted and the results for all zones summed to get the energy consumption for the total building. The results of this second phase of analysis is given in Figure 9.

The major changes in base assumptions from the first phase of the analysis were:

a. The building was 8 stories high with an aspect ratio of approximately $1.2: 1$ while the gross floor area remained the same,

b. as mentioned above, the building was modeled in zones, and

c. $100 \%$ of calculated heat gains or losses were assumed converted to loads.

Except for the changes above, computer Run 36 was a duplicate of Run 1 . As can be seen from Figure 9, the predicted energy consumption was $16.8 \times 10^{12} \mathrm{~J}\left(15.9 \times 10^{9} \mathrm{Btu}\right)$, (approximately 20\% higher than predicted in Run 1). Although the change in modeling technique and building aspect ratio undoubtly had some effect, the majority of the change resulted from $c$. above. In the first phase of the analysis, modeling the building as one large room approximately $24 \mathrm{~m}(80 \mathrm{ft})$ high coupled with the "transfer function" technique of converting heat gains or losses to loads [2] resulted in only about $80 \%$ of the gains or losses being converted to loads. Forcing this to be $100 \%$ thus caused the approximate $20 \%$ increase in predicted energy consumption.

Run 37 here corresponds to Run 20 in the first phase of the analysis. The percent decrease in predicted energy consumption between Runs 36 and 37 as shown in Figure 9 is 36\% 
which is in good agreement with the decrease between Runs 1 and 20 in the first phase of $35 \%$.

Runs 26, 28, and 29 represent minor additional design changes beyond those of Run 37 as follows:

Run $264.6 \mathrm{~m}$ (15 ft) wide solid panels (with no windows provided for the full building height) at the following locations:

North face - N.E. and N.W. corners

East face - S.E. corner

West face - S.W. corner

Run 28 The same as Run 26 except for movable shading on the south windows to automatically exclude solar gains that result in an increased cooling load and allow those solar gains which can be used to counteract heat losses.

Run 29 The same as Run 26 except that the east and west walls were designed as shown in Figure 10.

Even though these modifications resulted in little change in the predicted yearly energy consumption, a significant change ( $10 \%$ decrease below that of Run 26) resulted in Run 30 from changing the interior lighting intensity from an effective $31 \mathrm{~W} / \mathrm{m}^{2}\left(2.9 \mathrm{~W} / \mathrm{ft}^{2}\right.$ ) to $23 \mathrm{~W} / \mathrm{m}^{2}\left(2.1 \mathrm{~W} / \mathrm{ft}^{2}\right)$.

Runs 31, 32, and 33 represent other modifications to Run 26 as follows:

Run 31 The same as Run 26 except that the absorptivity of the east and west walls to solar radiation was assumed to be 0.45 .

Run 32 The same as Run 26 except that the window U-values were reduced to $0.57 \mathrm{~W} /$ $\left(\mathrm{m}^{2} \cdot{ }^{\circ} \mathrm{C}\right)\left(0.1 \mathrm{Btu} /\left(\mathrm{h} \cdot \mathrm{ft}^{2} \cdot{ }^{\circ} \mathrm{F}\right)\right)$ during unoccupied hours.

Run 33 The same as Run 26 except the mass of the walls was reduced to approximately $160 \mathrm{~kg} / \mathrm{m}^{3}\left(10 \mathrm{lb} / \mathrm{ft}^{3}\right)$ while maintaining a U-value of $0.34 \mathrm{~W} /\left(\mathrm{m}^{2} \cdot{ }^{\circ} \mathrm{C}\right)(0.06$ $\left.\mathrm{Btu} /\left(\mathrm{h} \cdot \mathrm{ft} \mathrm{t}^{2} \cdot{ }^{\circ} \mathrm{F}\right)\right)$.

As can be seen, the change in predicted yearly energy consumption for these cases was small.

A significant additional decrease in predicted yearly energy consumption was obtained in Run 35 from the following changes:

(a) Occupancy schedule was changed from 8 a.m. -5 p.m. to 9 a.m. -4 p.m.,

(b) lighting intensity was reduced to an effective $16.2 \mathrm{~W} / \mathrm{m}^{2}\left(1.5 \mathrm{~W} / \mathrm{ft}^{2}\right)$,

(c) ventilation rate was reduced from $3.35 \mathrm{~m}^{3} / \mathrm{s}(15,000 \mathrm{cfm})$ to $1.34 \mathrm{~m}^{3} / \mathrm{s}(6,000 \mathrm{cfm})$, and

(d) north wall had no windows

As can be seen, this represents a total decrease in predicted yearly energy consumption of almost $60 \%$ compared with the "typical design practice" building of Run 36.

Throughout these calculations the heat storage process in the building was accounted for by using approximate "weighting factors" as presented in the 1972 ASHRAE Handbook of Fundamentals [2]. This technique considerably shortens the calculation sequence required and hence the computer time to analyze a large number of design changes as in this study. 
As mentioned in Section 3. of this report, the normally used subroutine of NBSLD, called RMTMP, converts the various heat gains or losses into corresponding cooling or heating loads by solving a large number of heat balance equations simultaneously. With the weighting factor method, RMTMP is bypassed and the gains or losses are assumed to be converted into loads using a predetermined time-series equation. This technique has been shown to give results which substantially agree with the RMTMP calculation [11].

In order to evaluate the effect of insulation position in the walls, the more exact and time consuming calculation was performed using the optional subroutine. Although the results of this latter calculation could not be directly compared to the results of Runs 26 - 37 , the following statements can be made:

1. A west zone on one of the mid-floors was simulated for an entire year using all the data applicable to Run 26 and the insulation position on the outside wall was varied. When the insulation was moved from inside to outside, the maximum heating load increased $13 \%$, the yearly heating load remained practically the same, the maximum cooling load decreased 5\%, and the yearly cooling load decreased $8 \%$. These results were as expected. When the insulation is placed on outside of the wall, the additional mass of the wall itself must be heated up in the early morning hours during the heating season thus requiring a larger than normal capacity heating plant. This additional mass facing the interior is of benefit during the cooling season though since it absorbs a fraction of the heat gain during the day which would normally be felt as a cooling load and gives it up later in the evening when it is of little consequence.

2. NBSLD is present1y on a time-sharing computer system [5] and some additional information was obtained using this version of the program. Most of the parameters of Run 26 were used (exceptions noted in Table 4) to obtain the results in Table 4. The heating results were obtained by using the actual weather data for the month of January 1962 and the cooling results were obtained by using a steady periodic cooling design day cycle for the New Hampshire region.

If one compares the output of the three zones of Run 33 with those of Run 26, the conclusion is that a lightweight wall is just as effective as a heavy weight wall is affecting heating and cooling provided that the U-value is kept the same $\left(0.34 \mathrm{~W} / \mathrm{m}^{2} \cdot{ }^{\circ} \mathrm{K}(.06 \mathrm{Btu} /\right.$ $\left(\mathrm{h}-\mathrm{ft}^{2} \cdot{ }^{\circ} \mathrm{F}\right)$ ) in this case). One should be cautioned that the insulation position was on the inside in both cases and the true benefit of the heavyweight wall comes when the insulation is placed to the outside. In support of this, the more exact calculation method was used in conjunction with the data of Runs 26 and 33 and it was found that when the insulation was on the outside, going from a heavy to a lightweight wall resulted in a decrease in the maximum heating $10 a d$ by $7 \%$, and increase in yearly heating consumption by $2 \%$, an increase in maximum cooling by $5 \%$, and an increase in yearly cooling load by $4 \%$. In addition, it should be stated that the weight of the floor and interior mass is probably more important than the weight of the external walls as far as its contribution to the thermal storage capacity of the structure.

Run 34 was the same as Run 26 except that the ventilation rate was changed to $5.1 \mathrm{~m}^{3} /$ $\mathrm{s} \cdot \mathrm{m}^{2}$ (1 $\mathrm{cfm} / \mathrm{ft}^{2}$ ) of floor area* during unoccupied hours and under the following conditions:

a. Building temperature $>24^{\circ} \mathrm{C}\left(75^{\circ} \mathrm{F}\right)$

b. Outdoor air had a lower temperature than the indoor air, and

c. Use of the outdoor air did not impose a heating load.

The run was completed on a version of the heating and cooling load program that has the capability to study the effect of nighttime flushing. Results of the computations were:

* This would correspond to $60 \mathrm{~m}^{3} / \mathrm{s}(126,000 \mathrm{cfm})$ for the total building. 
a. Nighttime flushing in a mid-floor, west zone resulted in a reduction of the maximum cooling load by $38 \%$ and in total yearly cooling load by $15 \%$.

b. Nighttime flushing in a mid-floor, center zone resulted in no change in either maximum cooling load or total yearly cooling load. This is not unreasonable since the center zone was cooled continuously during the occupied hours so that the structure had already stored the cooling effect.

\section{Miscellaneous Design Day Calculations}

Run 26 building data and specifications were used to investigate detailed hourly profiles of room temperature and heating and cooling load as affected by various types of tẻmperature control.

Figure 11 shows the results of a standard design day calculation based upon the following assumptions :

1. Outdoor temperature profile shown was repeated on a steady periodic basis. This is to simulate a hot spell lasting more than 5 days.

2. The outdoor humidity was such that the dewpoint temperature remained constant at $16^{\circ} \mathrm{C}\left(60^{\circ} \mathrm{F}\right)$.

3. Solar radiation was for a clear sky at a latitude of 43 degrees.

4. Indoor temperature was maintained at $24^{\circ} \mathrm{C}\left(75^{\circ} \mathrm{F}\right)$ throughout the day and relative humidity of $50 \%$.

5. Lighting, equipment, and occupancy were for 8:00 a.m. to 5:00 p.m. only with the maximum values being:

$$
\begin{array}{ll}
\text { Lighting: } & 21.5 \mathrm{~W} / \mathrm{m}^{2}\left(2 \mathrm{~W} / \mathrm{ft}^{2}\right) \\
\text { Equipment: } & 5.4 \mathrm{~W} / \mathrm{m}^{2}\left(0.5 \mathrm{~W} / \mathrm{ft}^{2}\right) \\
\text { People: } & 9 \\
\text { Ventilation: } & 0.25 \mathrm{air} \text { change } / \mathrm{hr} \\
\text { Air Leakage: } & 0.25 \mathrm{air} \text { change } / \mathrm{hr}
\end{array}
$$

Subsequent calculations illustrated in Figures 12 through 18 were for different types of indoor temperature control, each step of which was directed toward decreasing the reduction of the total daily cooling load, but not necessarily to the reduction of the daily maximum cooling load.

In Figure 12, it is shown that the total daily cooling load was reduced from $3.346 \times 10^{8}$ $\mathrm{J} /$ day $\left(317,400 \mathrm{Btu} /\right.$ day) to $3.076 \times 10^{8} \mathrm{~J} /$ day $(291,700 \mathrm{Btu} /$ day $)$ by setting the nighttime temperature at $27^{\circ} \mathrm{C}\left(80^{\circ} \mathrm{F}\right)$. However, the maximum cooling load increased from $7,470 \mathrm{~W}(25,500$ $\mathrm{Btu} / \mathrm{h})$ to slightly above $8,780 \mathrm{~W}(30,000 \mathrm{Btu} / \mathrm{h})$.

In Figure 13, the nighttime flushing of 6 air changes per hour of the zone was incorporated as long as the zone temperature was above $24^{\circ} \mathrm{C}\left(75^{\circ} \mathrm{F}\right)$ and the outdoor temperature was less than $21^{\circ} \mathrm{C}\left(70^{\circ} \mathrm{F}\right)$. The oscillating pattern of the zone temperature shown in the 
early morning hours is due to the night-flushing control. The actual indoor temperature profile as indicated on a continuous pen would probably not be the same as shown in this figure. The daily total load was reduced to $2.535 \times 10^{8} \mathrm{~J} /$ day $(240,400 \mathrm{Btu} /$ day $)$ and the daily maximum was $8,200 \mathrm{~W}(28,000 \mathrm{Btu} / \mathrm{h})$.

In Figure 14, it was assumed further that the cooling load could not exceed 5,270 $\mathrm{W}$ $(18,000 \mathrm{Btu} / \mathrm{h})$ because of the maximum capacity of the cooling equipment. As a result of this constraint, it was no longer possible to maintain the zone temperature at $24{ }^{\circ} \mathrm{C}\left(75^{\circ} \mathrm{F}\right)$, as shown in this figure. The daily total load was, however, reduced to $2.294 \times 10^{8} \mathrm{~J} /$ day $(217,600 \mathrm{Btu} / \mathrm{day})$.

The operating condition assumed for the calculations of Figure 14 was again used for the calculations whose results are depicted in Figure 15. In addition to the cooling equipment being restricted to a maximum capacity of $5,270 \mathrm{~W}(18,000 \mathrm{Btu} / \mathrm{h})$, it was assumed shut down during the unoccupied hours. The daily cooling load for the operation was then $1.9 \mathrm{x}$ $10^{8} \mathrm{~J} /$ day $(180,000 \mathrm{Btu} /$ day) (occupied period was 10 hours).

In Figure 16, the air conditioning system was assumed completely shut down throughout the day to determine what would happen to the zone temperature. The zone temperature rose to $34{ }^{\circ} \mathrm{C}\left(94^{\circ} \mathrm{F}\right)$ during the latter part of the occupied hours, which is obviously unacceptable from the standpoint of human comfort.

Figures 17 and 18 show summer hourly load profiles for the west facing zone on the top floor where the assumptions were: $50 \%$ glass in exterior walls, a constant indoor temperature of $24^{\circ} \mathrm{C}\left(75^{\circ} \mathrm{F}\right)$, and a nighttime temperature setting of $27^{\circ} \mathrm{C}\left(80^{\circ} \mathrm{F}\right.$ ) including flushing. Also shown in these figures are the effect of changing the position of insulation in the wall. As can be seen, placing the insulation outside does show a decrease in the maximum cooling load, but the decreases are not significant.

Shown in Figure 19 are the results of calculations that were carried out for the west facing zone of the top floor by using hour by hour weather data for January 29, 1962 . The figure shows the effect of window size ( $10 \%$ and $50 \%$ of exterior wal1) and of position of insulation (inside or outside of the concrete masonry unit) on the heating load. The indoor temperature was assumed to follow the nighttime setback pattern as indicated. It was a characteristic of this zone that there existed an exceptionally large maximum heating load at the time when the temperature set point was changed from nighttime $16^{\circ} \mathrm{C}\left(60^{\circ} \mathrm{F}\right)$ to $21{ }^{\circ} \mathrm{C}$ $\left(70^{\circ} \mathrm{F}\right)$ for the occupied period. Moreover, the maximum heating load was larger when the insulation was placed outside of the concrete masonry unit as compared to when it was placed inside.

In order to examine whether a gradual temperature increase from $16{ }^{\circ} \mathrm{C}\left(60{ }^{\circ} \mathrm{F}\right)$ to $21{ }^{\circ} \mathrm{C}$ $\left(70^{\circ} \mathrm{F}\right)$ would decrease the maximum hourly load as compared to the sudden step change shown in the previous figure, calculations were done for a linear temperature change from $16^{\circ} \mathrm{C}\left(60^{\circ} \mathrm{F}\right)$ to $21{ }^{\circ} \mathrm{C}\left(70^{\circ} \mathrm{F}\right)$ over a five hour period between 2:00 a.m. and 7:00 a.m. The results are shown in Figure 20. The maximum heating load was unaffected by the gradual temperature change. The reason for this ineffectiveness by this preheating is that the heating during the preoccupied period was done without the assistance of occupants, electric lights, or equipment.

\section{Analysis of the Final Building Design}

Based upon pre-design analysis and recommendations, the architects prepared the final drawings of the building. A rendering of the building is shown in Figure 21 and a schematic showing the floor area on each of seven floors, basement and subbasement is shown in Figure 22. Table 5 provides the final construction details of the roof, walls, floor/ceiling and Tables 6 and 7 specify other pertinent data that was required to simulate, with NBSLD, this final building design. 
The design heating and cooling loads were first calculated for the following climatic conditions on a steady-state and steady-periodic basis respectively:

\begin{tabular}{|c|c|c|}
\hline Heating - & Average Outdoor Temperature & $-15.0^{\circ} \mathrm{C}\left(5^{\circ} \mathrm{F}\right)$ \\
\hline & Average Outdoor Dewpoint Temperature & - \\
\hline & Indoor Temperature & $21{ }^{\circ} \mathrm{C}\left(70^{\circ} \mathrm{F}\right)$ \\
\hline & Indoor Relative Humidity & $20 \%$ \\
\hline Cooling - & Maximum Dry-Bulb Temperature & $32{ }^{\circ} \mathrm{C}\left(90^{\circ} \mathrm{F}\right)$ \\
\hline & Minimum Dry-Bulb Temperature & $19^{\circ} \mathrm{C}\left(66^{\circ} \mathrm{F}\right)$ \\
\hline & Dewpoint Temperature & $16{ }^{\circ} \mathrm{C}\left(60^{\circ} \mathrm{F}\right)$ \\
\hline & Sky & Clear \\
\hline & Indoor Temperature & $24^{\circ} \mathrm{C}\left(75^{\circ} \mathrm{F}\right)$ \\
\hline & Indoor Relative Humidity & $50 \%$ \\
\hline
\end{tabular}

The calculations were performed on four zones; west, south, east, and core on the lst, 2nd, 3rd, and 7th floor. The north zone that was previously used in the zone simulations was included in the core zone here because it has no windows. The 4 th, 5th, and 6 th floors are identical with the 3 rd floor for the purposes of this simulation.

Table 8 lists the results of hourly heating and cooling load calculations. Computations were carried out using a 1962 weather tape. Each of the sixteen zones were simulated and the data were used to determine the hourly loads for each of the four different floors. This information will be used subsequently for system simulation analysis.

Hourly heating and cooling loads are shown in Figures 23, 24, and 25 on the basis of $\left.\mathrm{Btu} / \mathrm{h} \cdot \mathrm{ft}^{2}\right)$ of floor area for the ground floor, middle floors, and the top floor respectively. All of these figures show distinctive gaps in the load pattern during the weekends and national holidays. The load per unit floor area was the highest for the ground floor and lowest for the middle floors. The monthly and annual heating and cooling loads which resulted from the calculations are given in Table 9. Using similar assumptions for the energy consumption estimates in the building design of Run 1, the annual energy consumption for the final design is approximated to be only $40 \%$ of that based upon the building of "Typical Design Practice". The monthly profiles of predicted energy expenditures for the final design building is depicted in Figure 26.

Some results of the system simulation for this final building design are shown in Figures 27 through 31 . Figure 27 depicts the hourly outdoor temperature as well as heating and cooling load for the four different zones in the top floor. It shows a very high heating requirement during the early hours of the occupancy period when the thermostat was set from $16^{\circ} \mathrm{C}\left(60^{\circ} \mathrm{F}\right)$ to $21.1^{\circ} \mathrm{C}\left(70^{\circ} \mathrm{F}\right)$. The central zone, however, soon required cooling as the lights were turned on and the heat from the occupants began to be released. The heating and cooling requirements became zero immediately after the building was vacated but the exterior zones required heating in order to maintain $16^{\circ} \mathrm{C}\left(60^{\circ} \mathrm{F}\right)$ due to the low outdoor temperature.

Figure 29 shows the total hourly thermal load for the top floor which was obtained by summing up the hourly heating load and load due to ventilation air of all the zones on the floor. 
The lower line in this figure represents the net heating load based on the assumption that the heat gain in the central zone was converted into useful heat for the perimeter zones by a heat reclaim system. Whereas Figures 27 and 28 were for a typical winter weekday, Figure 29 shows a plot for January 19 and 20 or the same year in order to show the change in heating load pattern for a weekend.

The high maximum heating requirement for the early hours shown in these last three figures are very typical of thermostat setback operation during the heating season. In reality, however, the actual heating capacity of a system may not match the high peak demand, resulting in the room temperature falling somewhere between $16{ }^{\circ} \mathrm{C}\left(60^{\circ} \mathrm{F}\right.$ ) and $21{ }^{\circ} \mathrm{C}$ (70 ${ }^{\circ} \mathrm{F}$ ) until such time as the heating load balances the heating capacity of the system.

Figure 30 shows the outdoor air temperature and the cooling load for four different" zones in the top floor during July 20, 1962. The cooling load for all the four zones fell to zero after the zone was vacated and thermostat setback to $27{ }^{\circ} \mathrm{C}$ ( $80^{\circ} \mathrm{F}$ ). Since no zone required heating during this particular day, the floor thermal load was exactly equal to the summation of hourly cooling load of these four zones.

Assuming that each zone is to be fed by a variable volume system with the air handling unit supplying the cooled and saturated air at $13^{\circ} \mathrm{C}\left(55^{\circ} \mathrm{F}\right)$, air supply to each zone was calculated to satisfy the cooling load. This was done by a special routine written for this phase of the study. A part.of the return air from all four zones on the same floor (which was assumed to be at $27^{\circ} \mathrm{C}\left(80^{\circ} \mathrm{F}\right)$ and $\left.50 \% \mathrm{RH}\right)$ was assumed mixed with the outdoor ventilation air to form the entering condition to the air handling system. The amount of recirculated air was determined by subtracting the quantity of outdoor air needed for ventilation purposes from the return air*. The cooling load imposed upon the coil was the heat contained in the air entering the air handling unit plus the heat given off from the fan. The computer routine computed the enthalpy of the air entering and leaving the coil by the use of psychrometric calculations which in turn gave the total air load. The results for July 20 , 1962 are shown in Figure 31.

During the period when the space required heating, the air supply rate was always equal to a minimum ventilation rate. In addition, in the air system simulation, it was assumed that:

1. Ventilation rate was zero during the unoccupied hours.

2. Toilet exhaust air exchanged heat with the ventilation air during the heating season for the purpose of preheating the ventilation air.

3. An economizer cycle was employed as long as the supply air temperature could be brought down to $16^{\circ} \mathrm{C}\left(60^{\circ} \mathrm{F}\right)$ by the increased use of outdoor air and as long as the outdoor air did not cause a load exceeding the maximum design capacity.

4. The heat rejected from the chiller that provided chilled water to the core zone was calculated and used to supplement the perimeter heating requirement. If the heat rejected from the chiller was more than that required for perimeter heating, it was assumed stored until the storage capacity exceeded $8.81 \times 10^{8} \mathrm{~J}(836,000 \mathrm{Btu})$. The excess was considered discharged to the atmosphere by way of a cooling tower. The amount of heat rejected at the chiller was estimated by an assumed chiller performance characteristic as follows:

Cooling Load, \%

100
Power, \%

100 (continued)

* In many cases, the supply air requirement necessary to satisfy the cooling load to all of the zones was less than what was required for ventilation. In that event, recirculation of return air was discontinued and $100 \%$ outdoor air was used as the entering condition to the air handling unit. 

tively.

The $100 \%$ load and power were assumed to be $35,145 \mathrm{~W}(120,000 \mathrm{Btu} / \mathrm{h})$ and 12,000 , respec-

\section{Summary}

Energy analysis based upon comprehensive hourly heating and cooling load calculations have been conducted for a Manchester, New Hampshire office building designed according according to "Typical Design Practice". Summary results for predicted yearly energy consumption as well as cooling and heating loads for typical summer and winter days have been presented for a variety of alternate building designs and kinds of operation.

\section{References}

1. "Local Climatological Data, Annual Summary With Comparative Data, Concord, New Hampshire", U. S. Department of Commerce, National Oceanic and Atmospheric Administration, Environmental Data Service, 1971.

2. ASHRAE Handbook of Fundamentals, American Society of Heating, Refrigerating and AirConditioning Engineers, 345 East 47th Street, New York, New York 10017.

3, "Proposed Procedure for Test Year Weather Data", ASHRAE Task Group on Energy Requirements for Heating and Cooling, American Society of Heating, Refrigerating and Air-Conditioning Engineers, 345 East 47th Street, New York, New York 10017, January 29, 1973.

4. T. Kusuda, and F. J. Powe11, "Use of Modern Computer Programs to Evaluate Dynamic Heat Transfer and Energy Use Processes in Buildings", National Bureau of Standards Special Publication 361, Volume 1: Performance Concept in Buildings; Proceedings of the Joint RILEM-ASTM-CIB Symposium, held May 2-5, Philadelphia, Pennsylvania (issued March, 1972).

5. T. Kusuda, "NBSLD", Heating and Cooling Load Calculation Program", APEC Journal, Vol. VIII, No. 6, Winter 1973/74.

6. T. Kusuda, "NBSLD, Computer Program for Heating and Cooling Loads in Buildings", NBS Report NBSIR 74-574, November, 1974.

7. "Procedures for Determining Heating and Cooling Loads for Computerized Energy Calculations", ASHRAE Task Group on Energy Requirements for Heating and Cooling, American Society of Heating, Refrigerating and Air-Conditioning Engineers, 345 East 47 th Street, New York, New York 10017, 1971.

8. B. A. Peavy, F. J. Powel1, and D. M. Burch, "Thermal Performance of an Experimental Masonry Building", NBS Building Science Series 45, 1973.

9. B. A. Peavy, D. M. Burch, and F. J. Powell, "Comparison of Measured and ComputerPredicted Thermal Performance of a Four Bedroom Wood-Frame Townhouse", NBS Building Science Series 57, 1975.

10. D. M. Sanders, and G. T. Tamura, "A Fortran IV Program to Simulate Air Movement in Multi-Story Buildings", DBR Computer Progran No. 35, National Research Council of Canada, Ottawa, March, 1973.

11. J. E. Hill, and R. R. Furlong, "ASHRAE Cooling Load Calculation", ASHRAE Journal, pp. 61-66, May, 1973. 
$1 \mathrm{mile}=1.609 \mathrm{~km}$

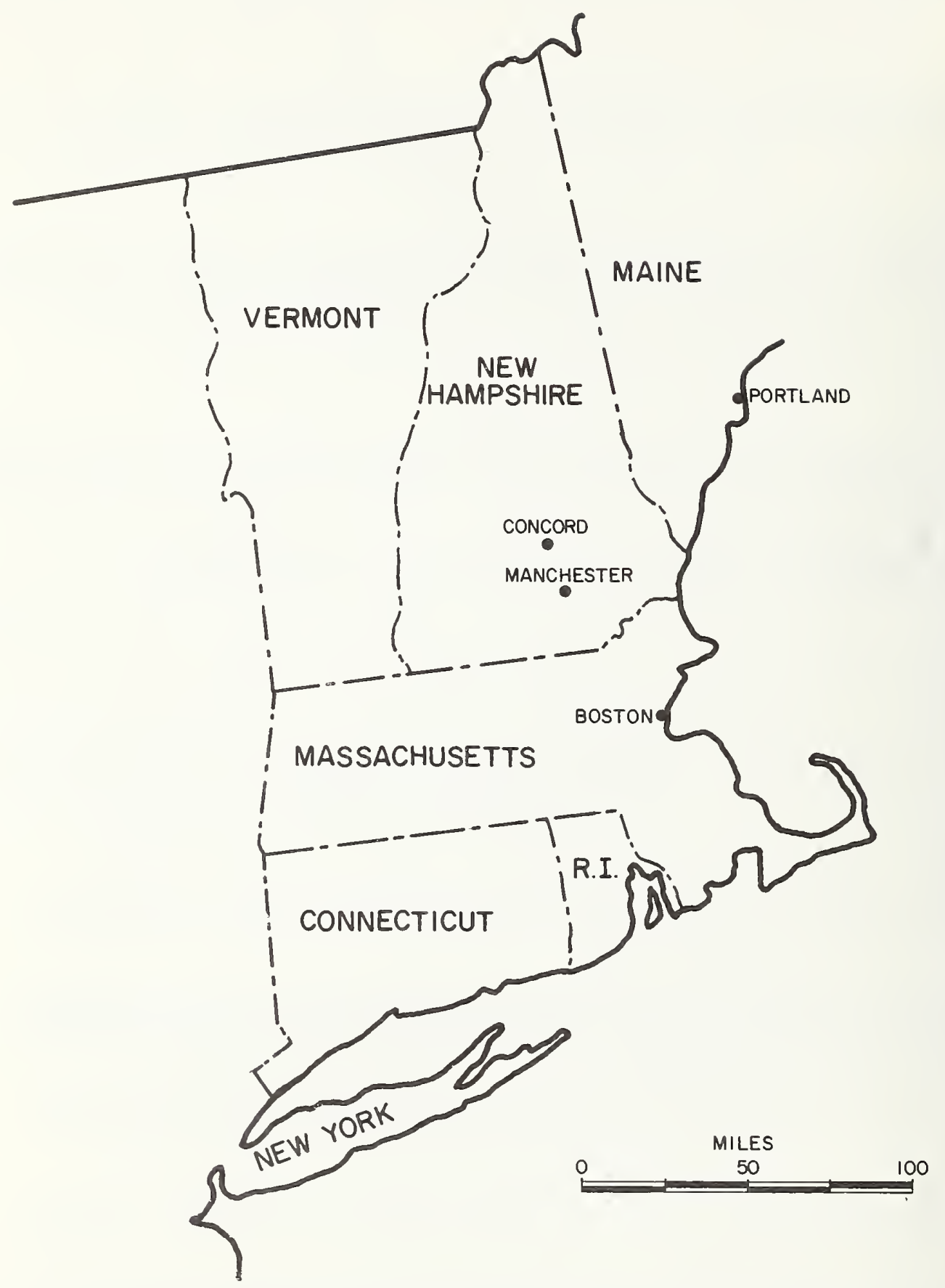

Figure 1. Relative Location of Manchester, New Hampshire. 
OUTDOOR TEMPERATURE
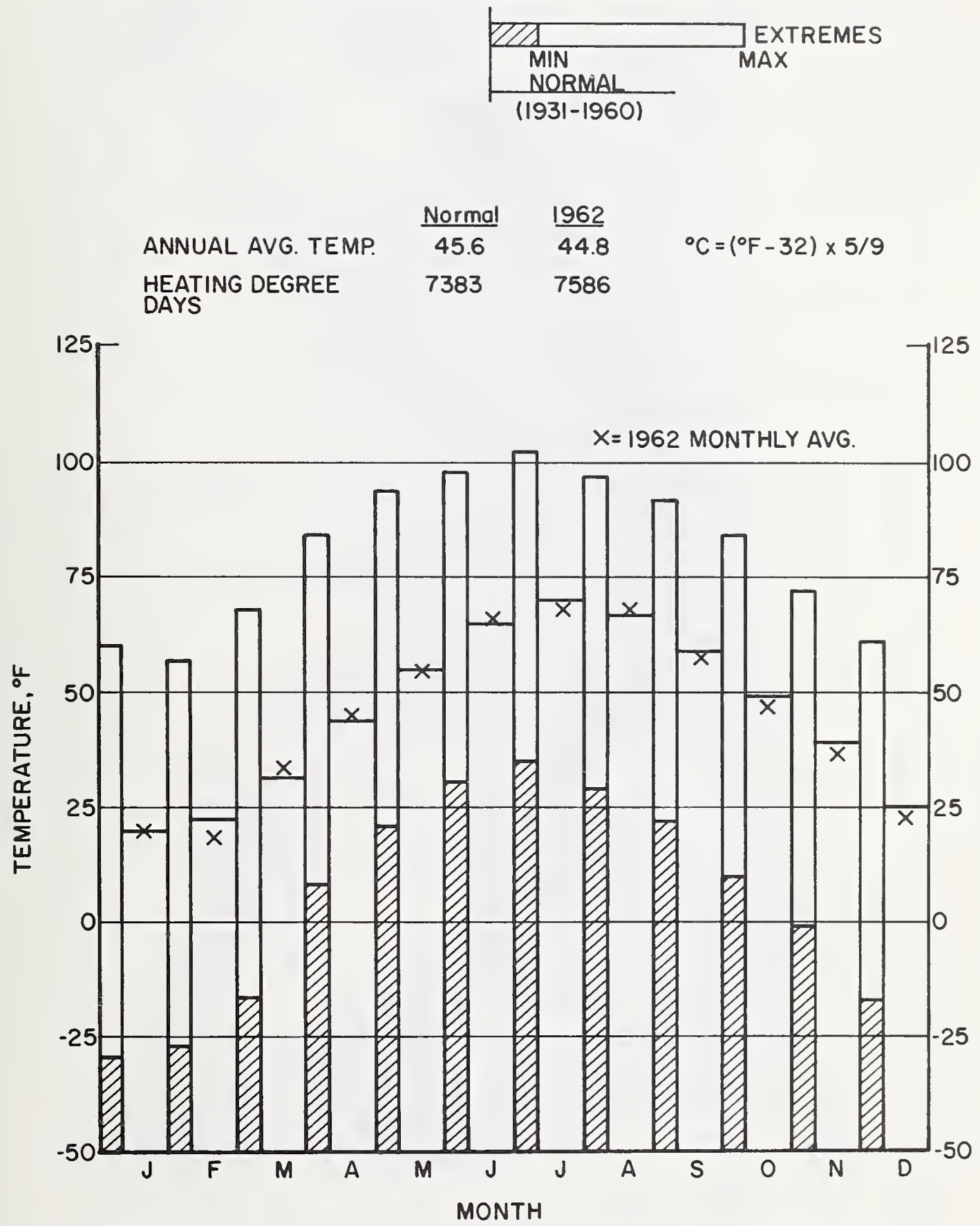

Figure 2. Monthly Average Temperature of Concord, New Hampshire. 


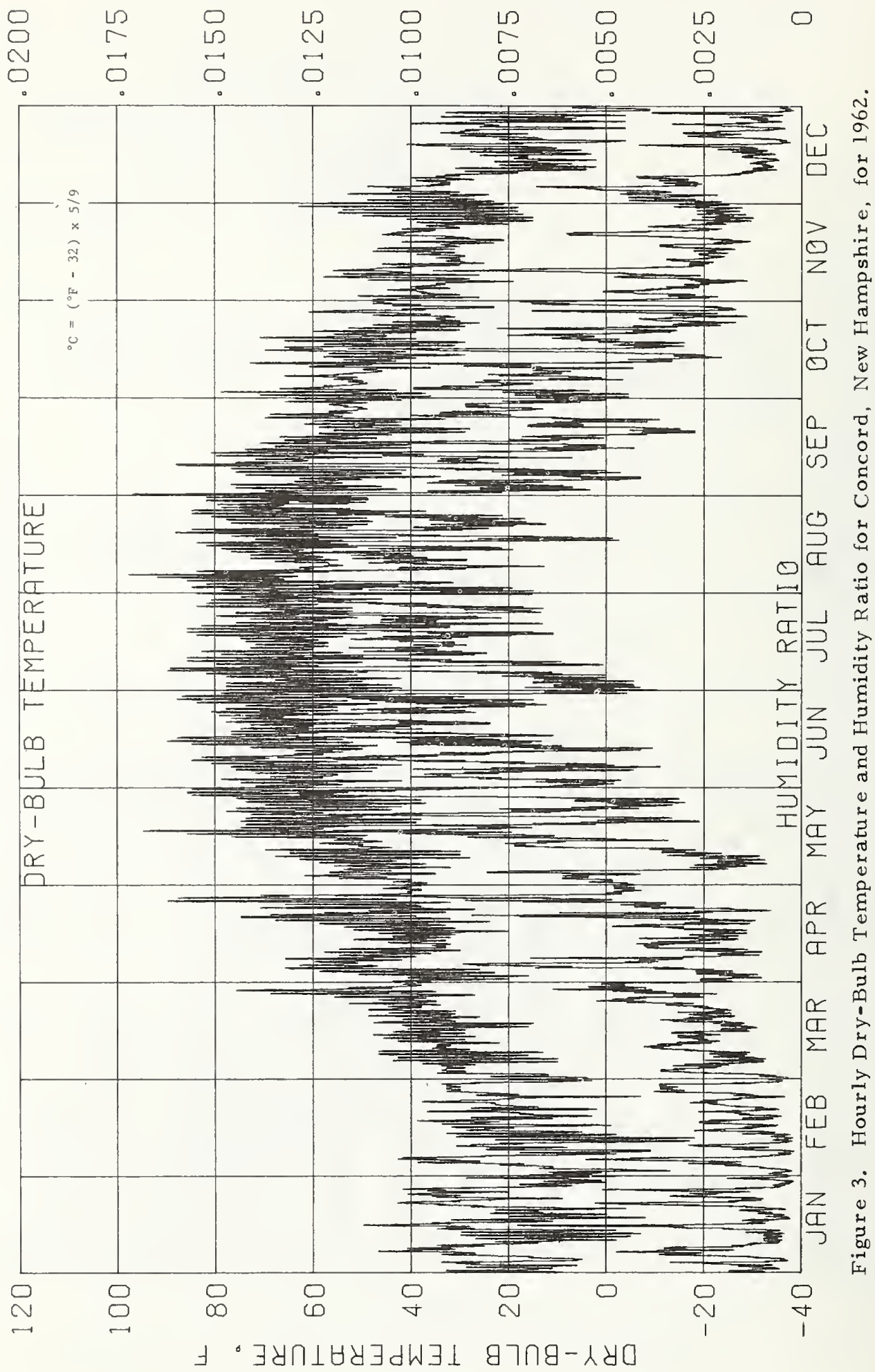




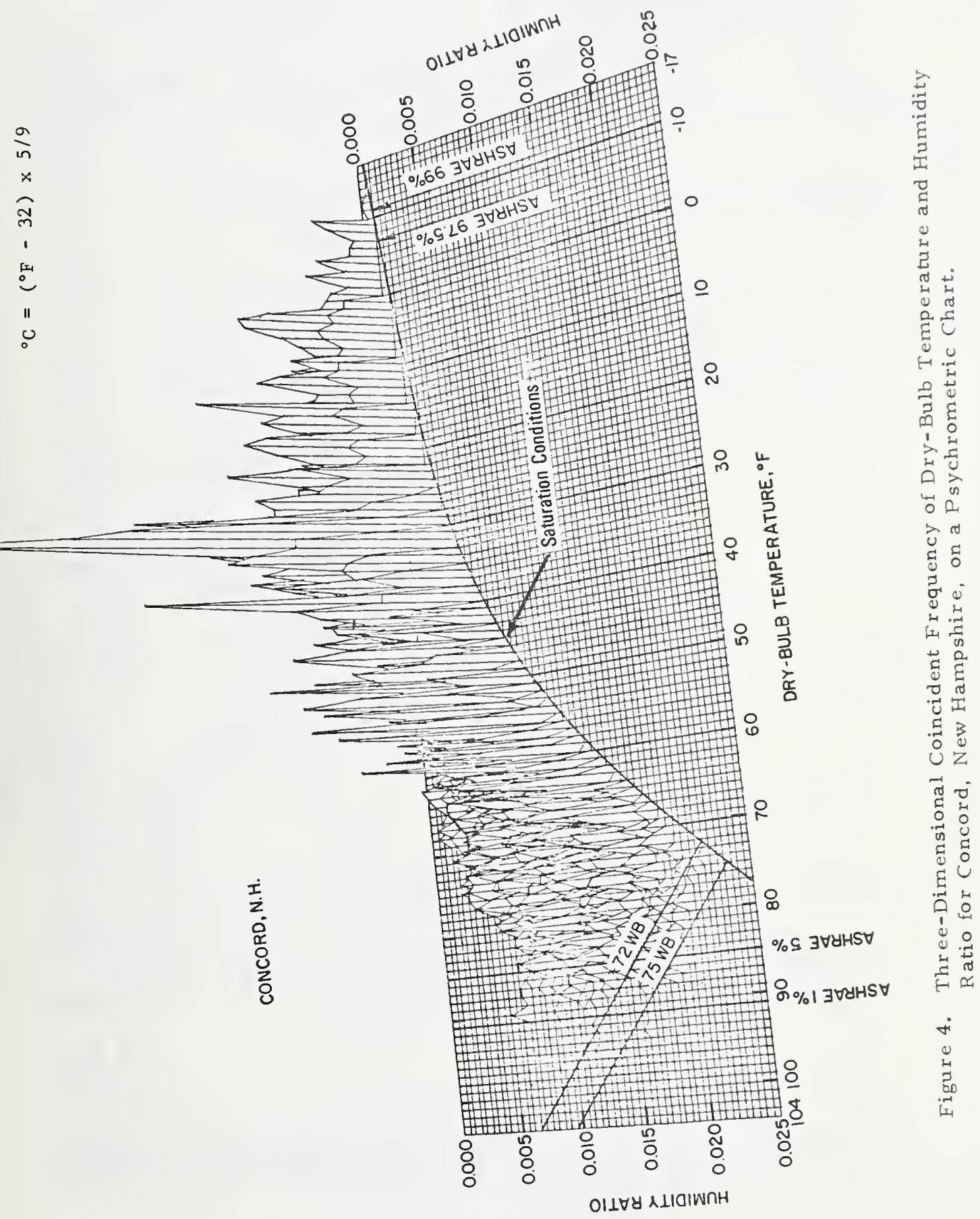




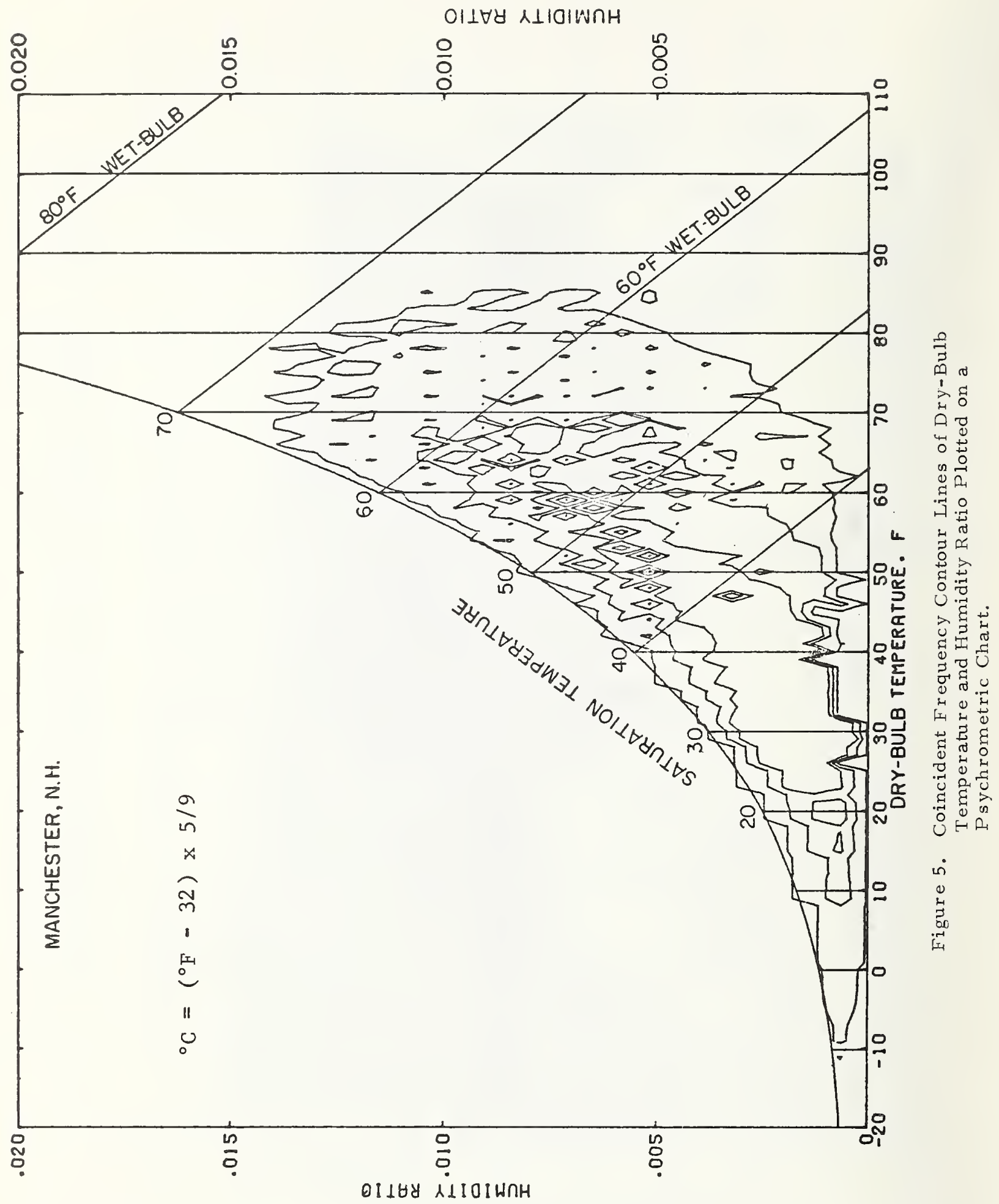




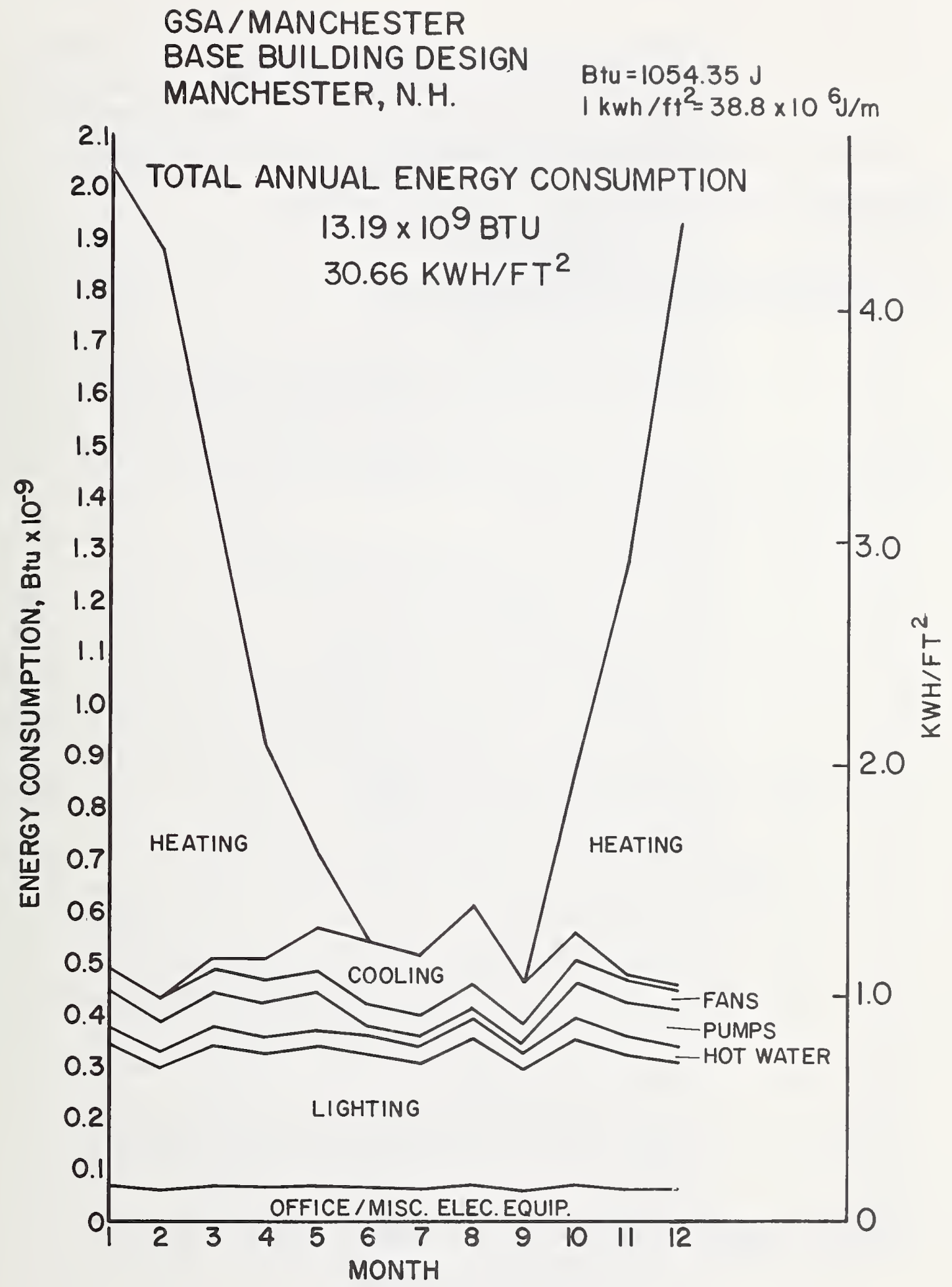

Figure 7. Predicted Monthly Profile of Annual Energy Consumption for the "Typical Design Practice" Building. 


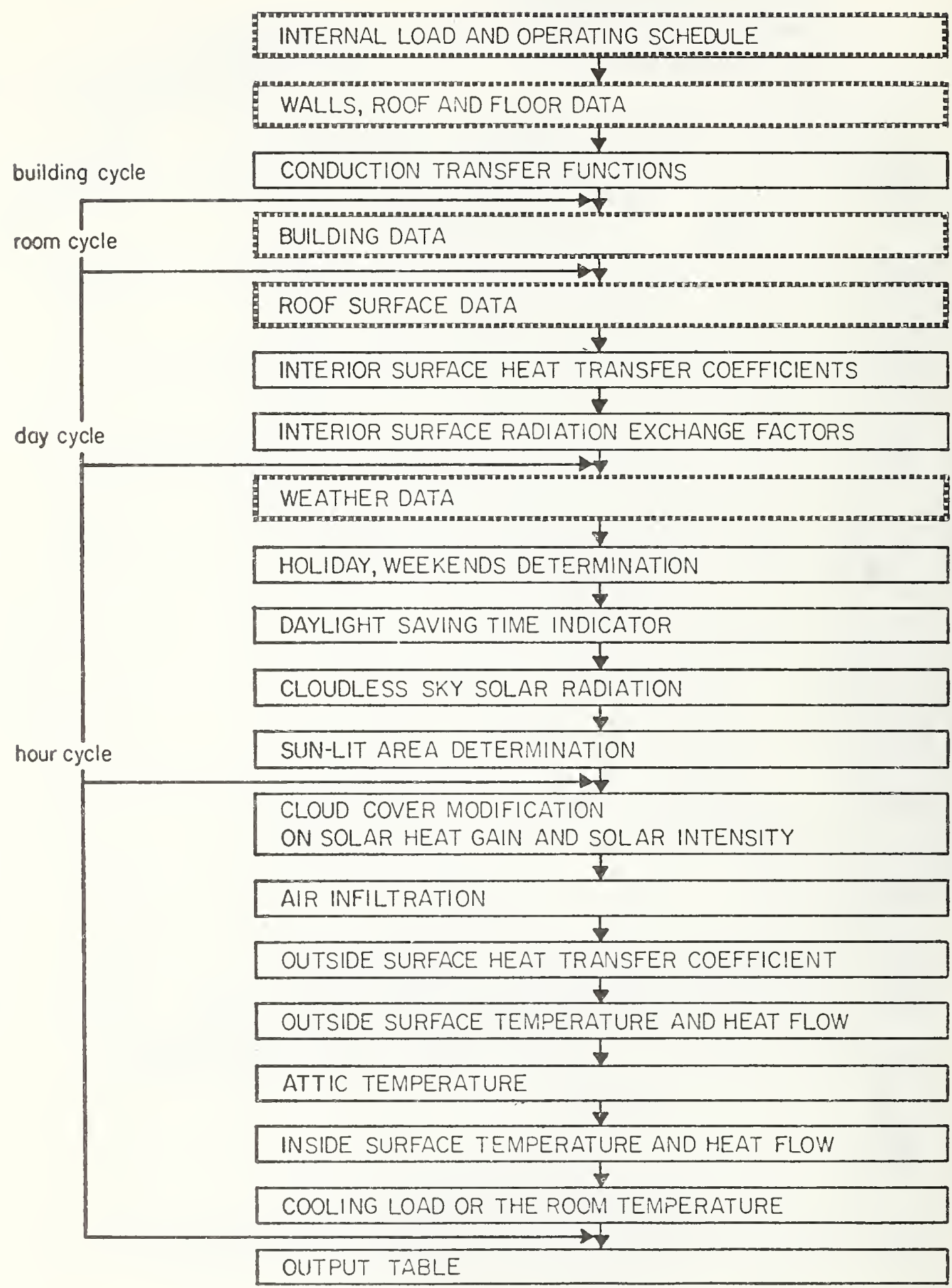

Figure 6. Calculation Sequence of NBSLD. 


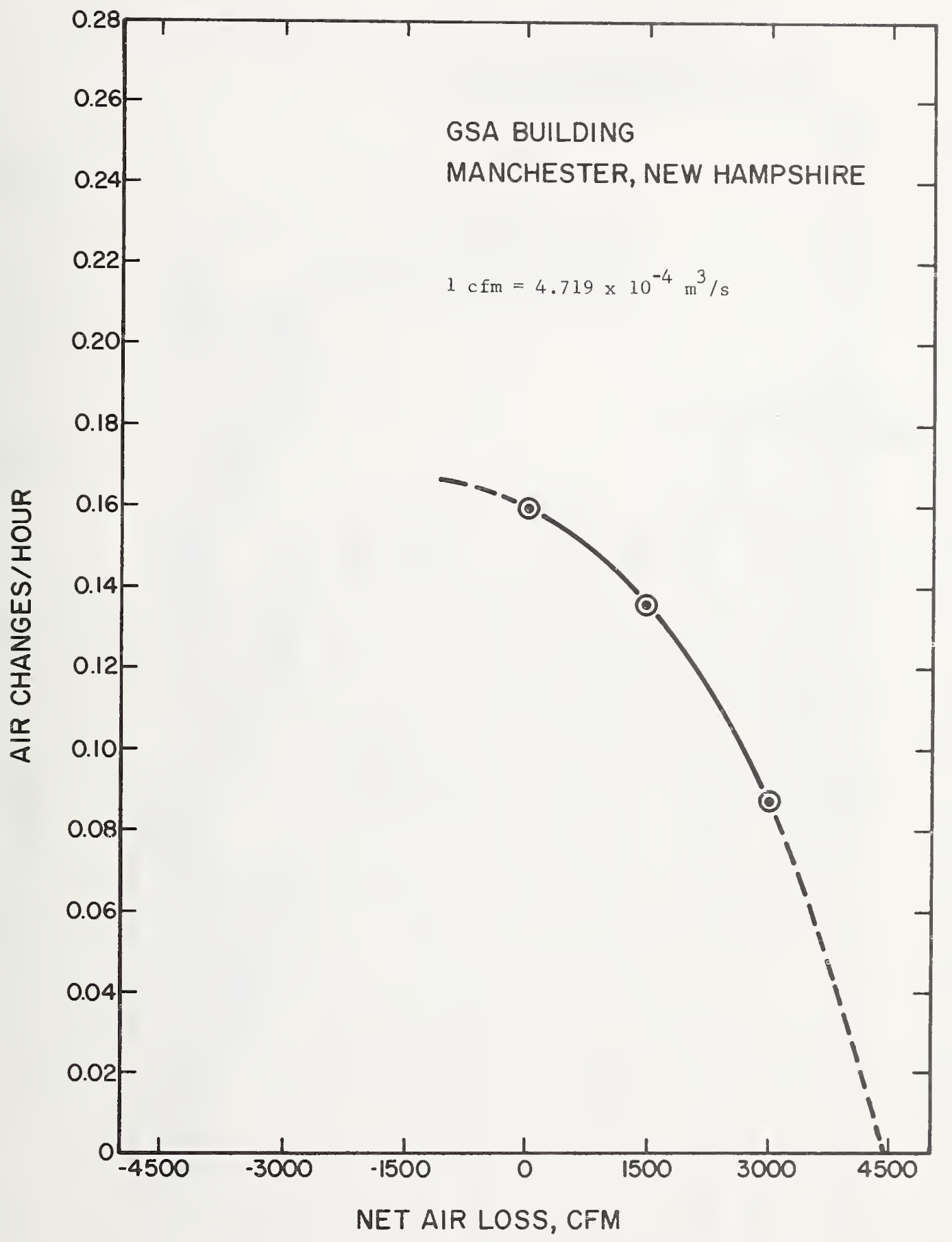

Figure 8. Air Inflitration Rate Versus Net Air Flow Loss from the Manchester Building. 


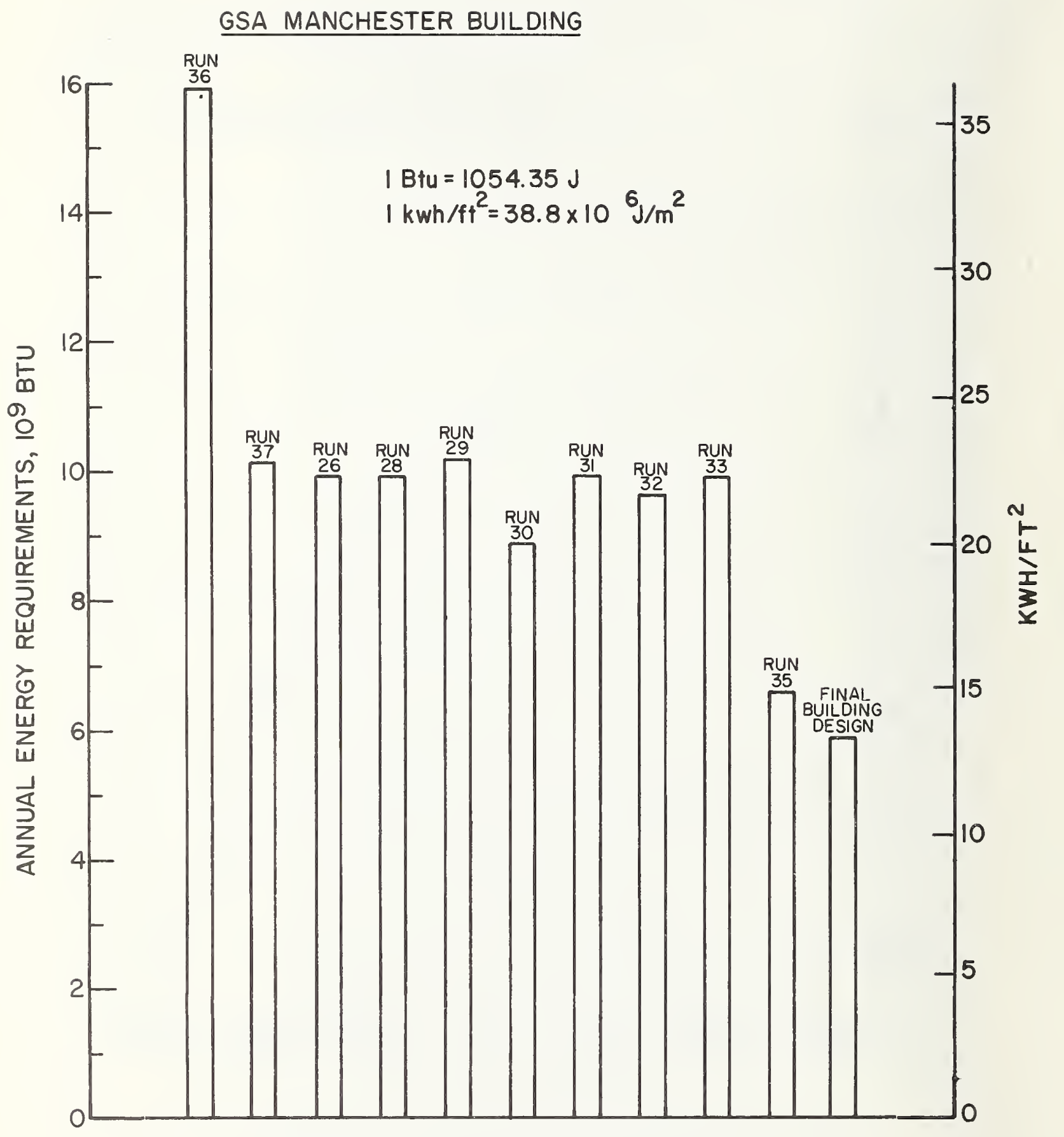

Figure 9. Predicted Annual Energy Consumption R esults for Various Simulation Calculations. 

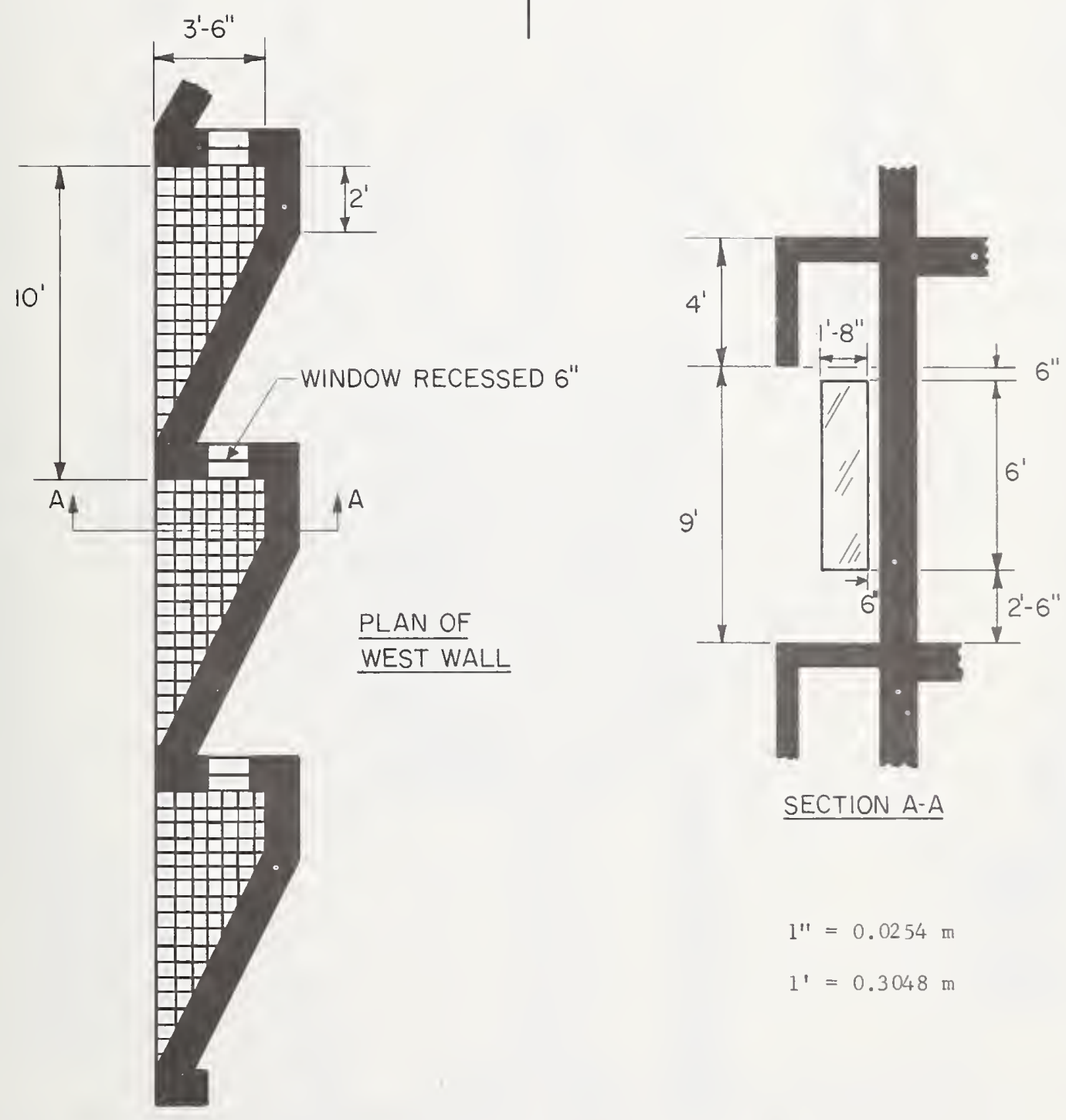

SECTION A-A

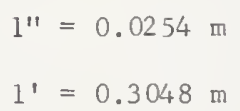

Figure 10. Schematic Diagram of the West Wall for One Possible Design. 
' $4 H / O \perp E$ ' $0 \forall 07$ 9NITOOJ

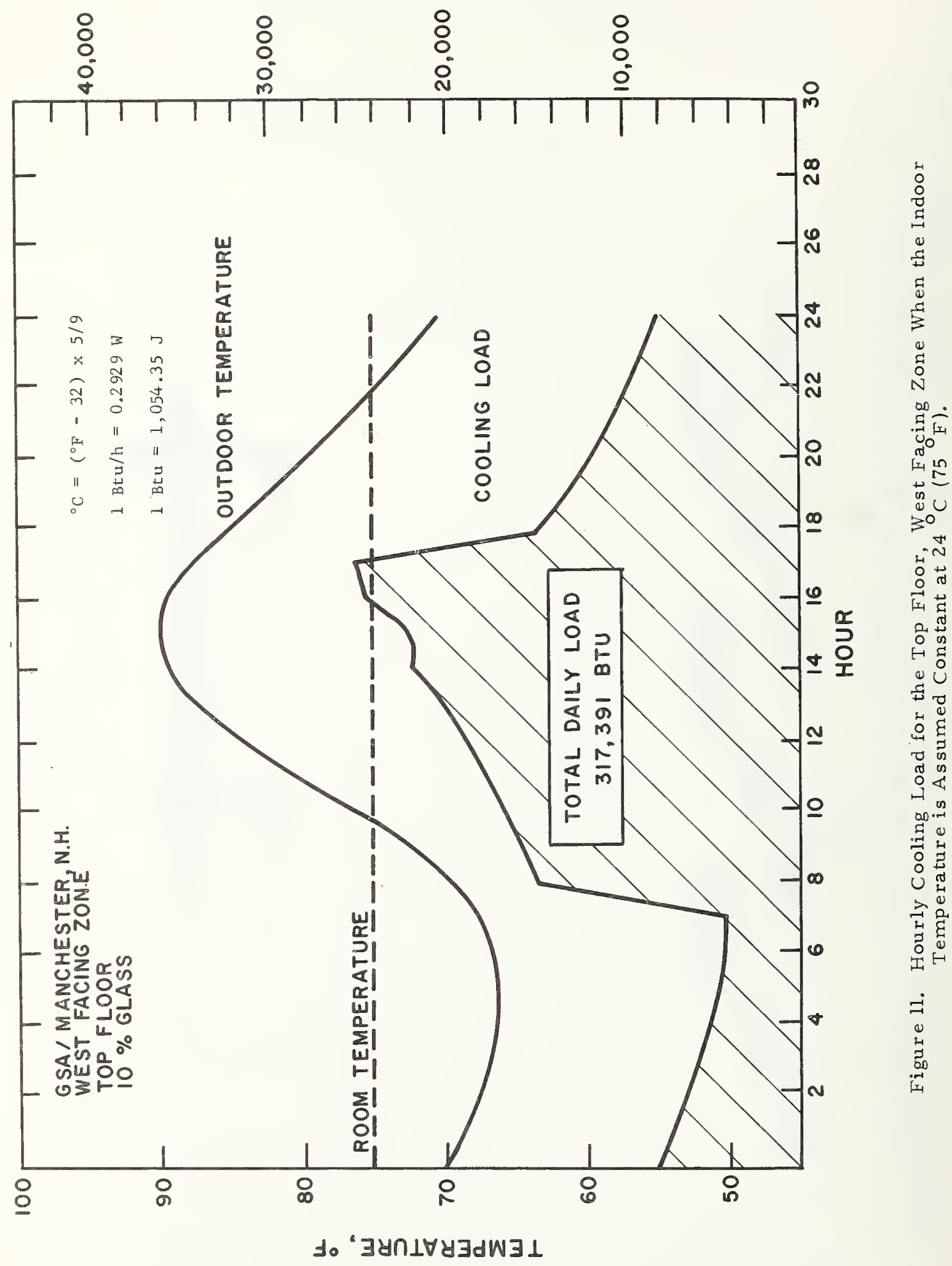




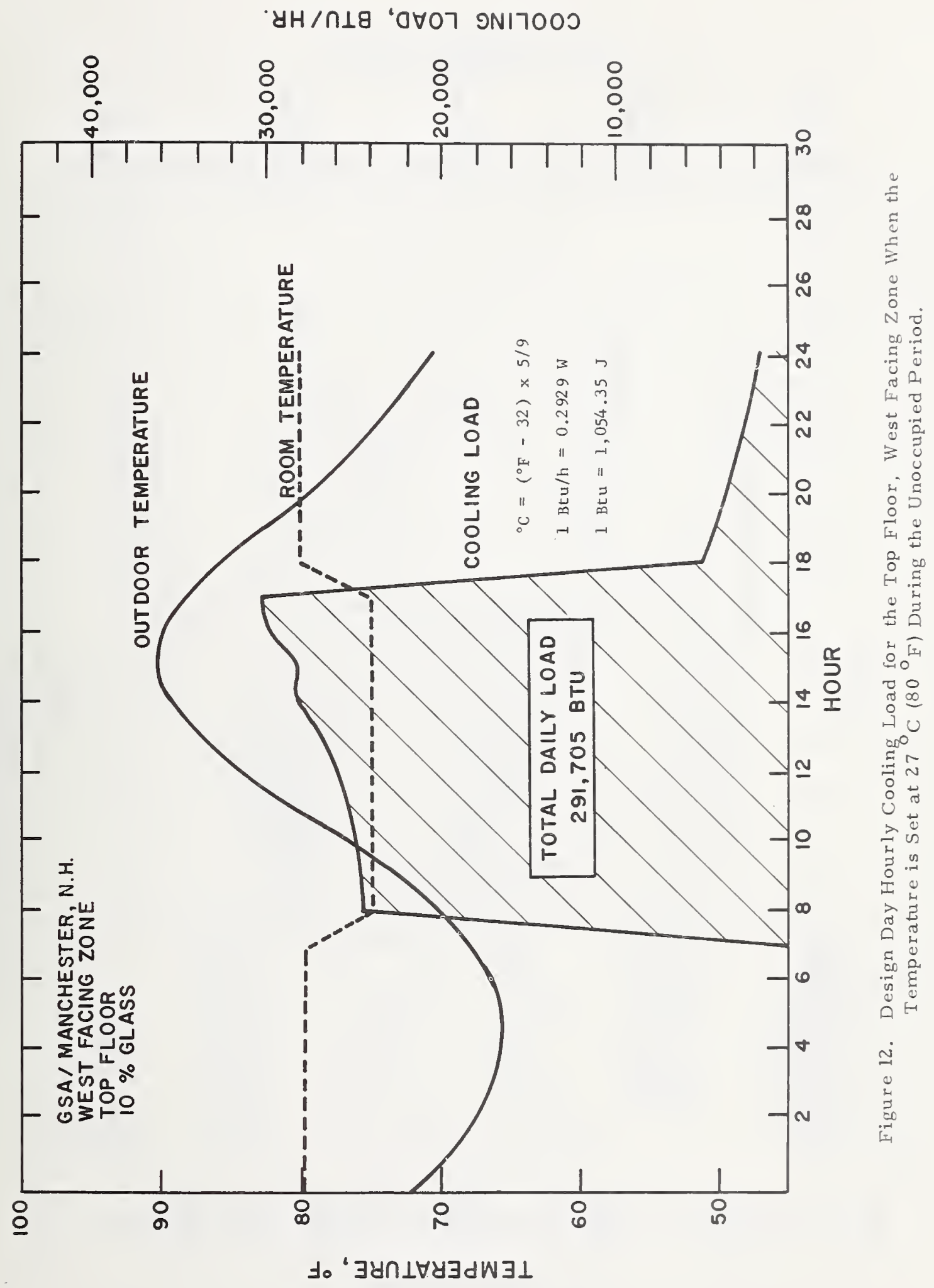


'UH/OLG 'OHOT 9NITOOJ

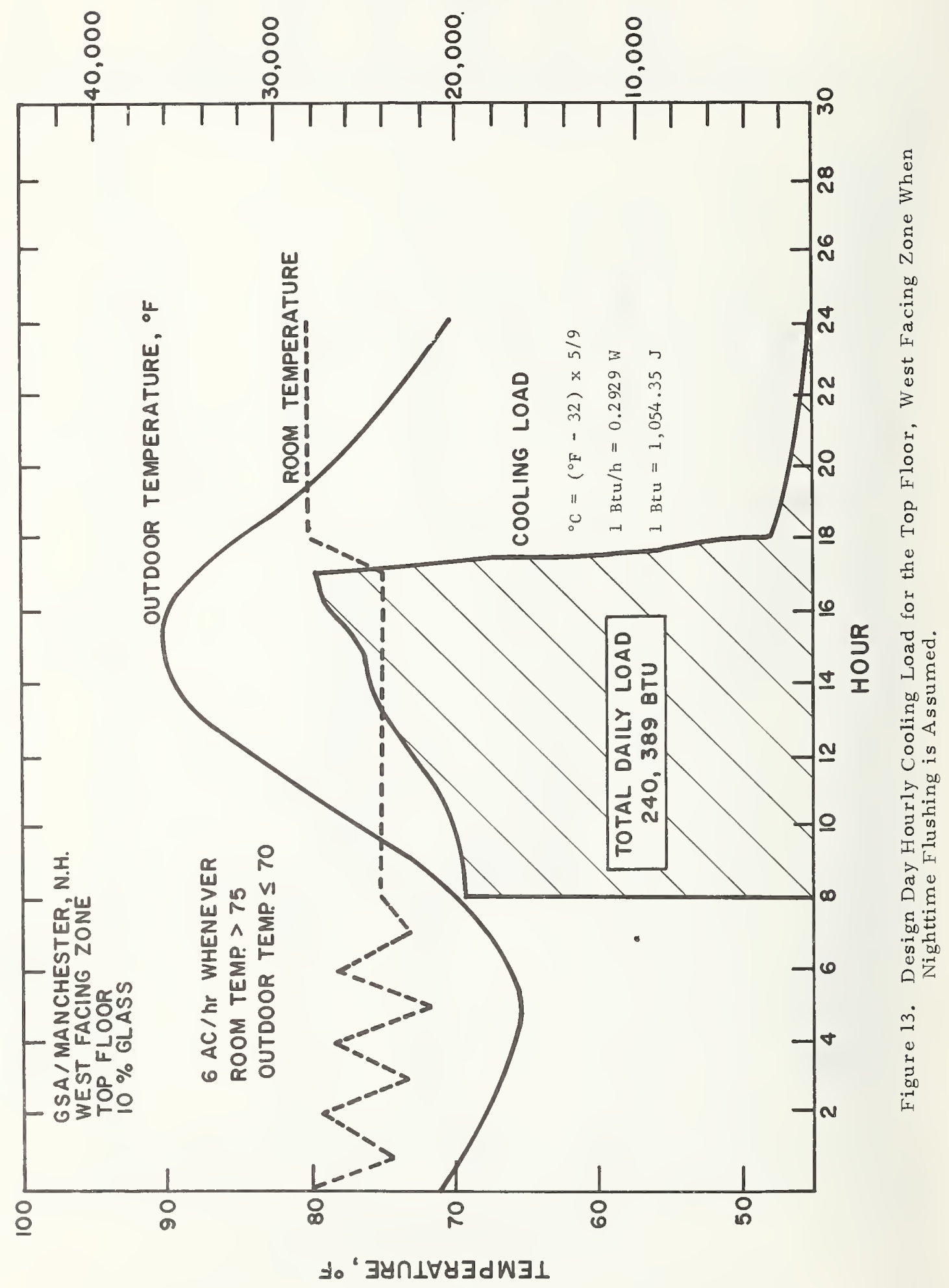




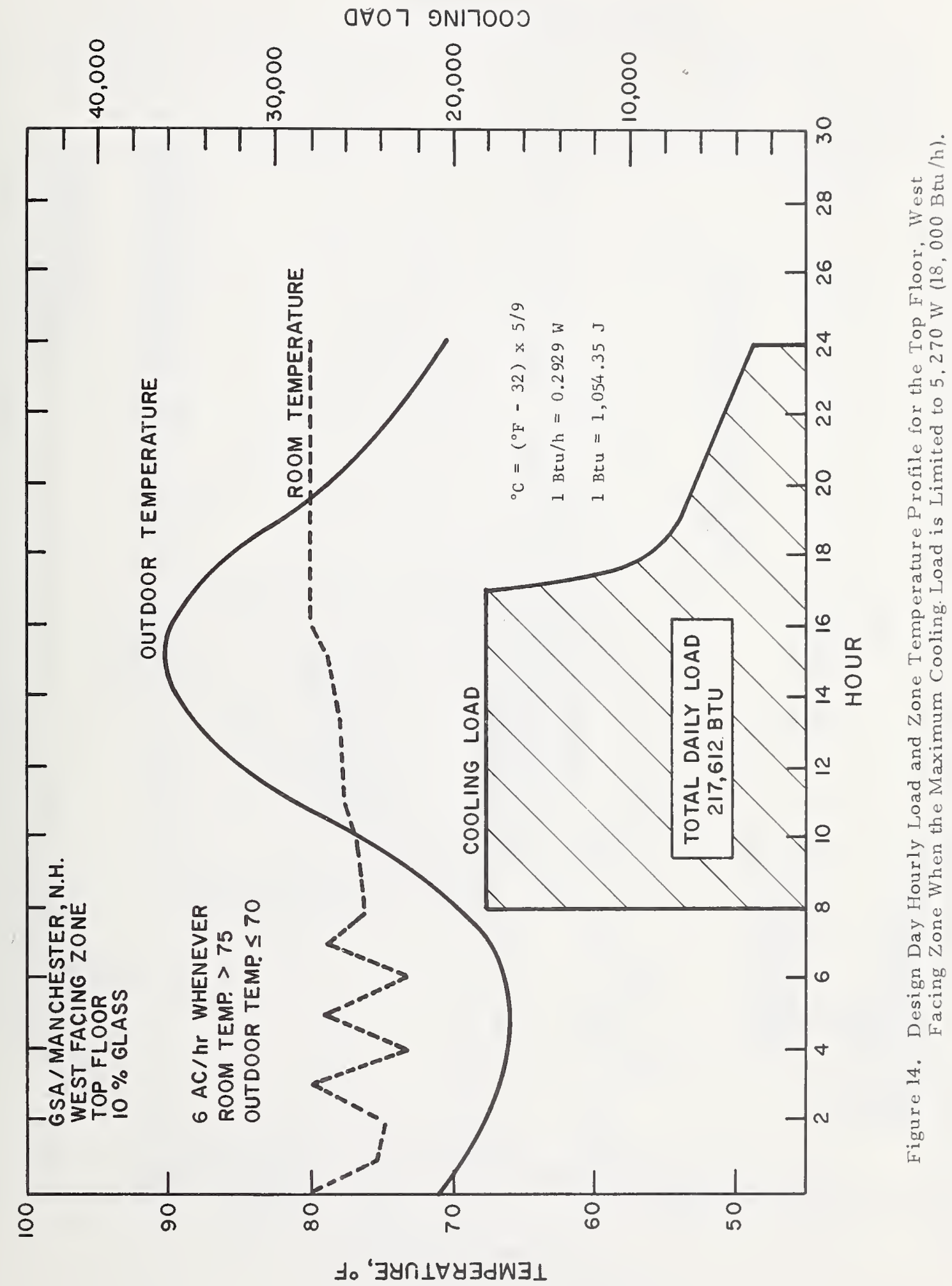




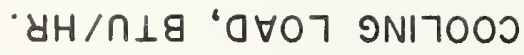

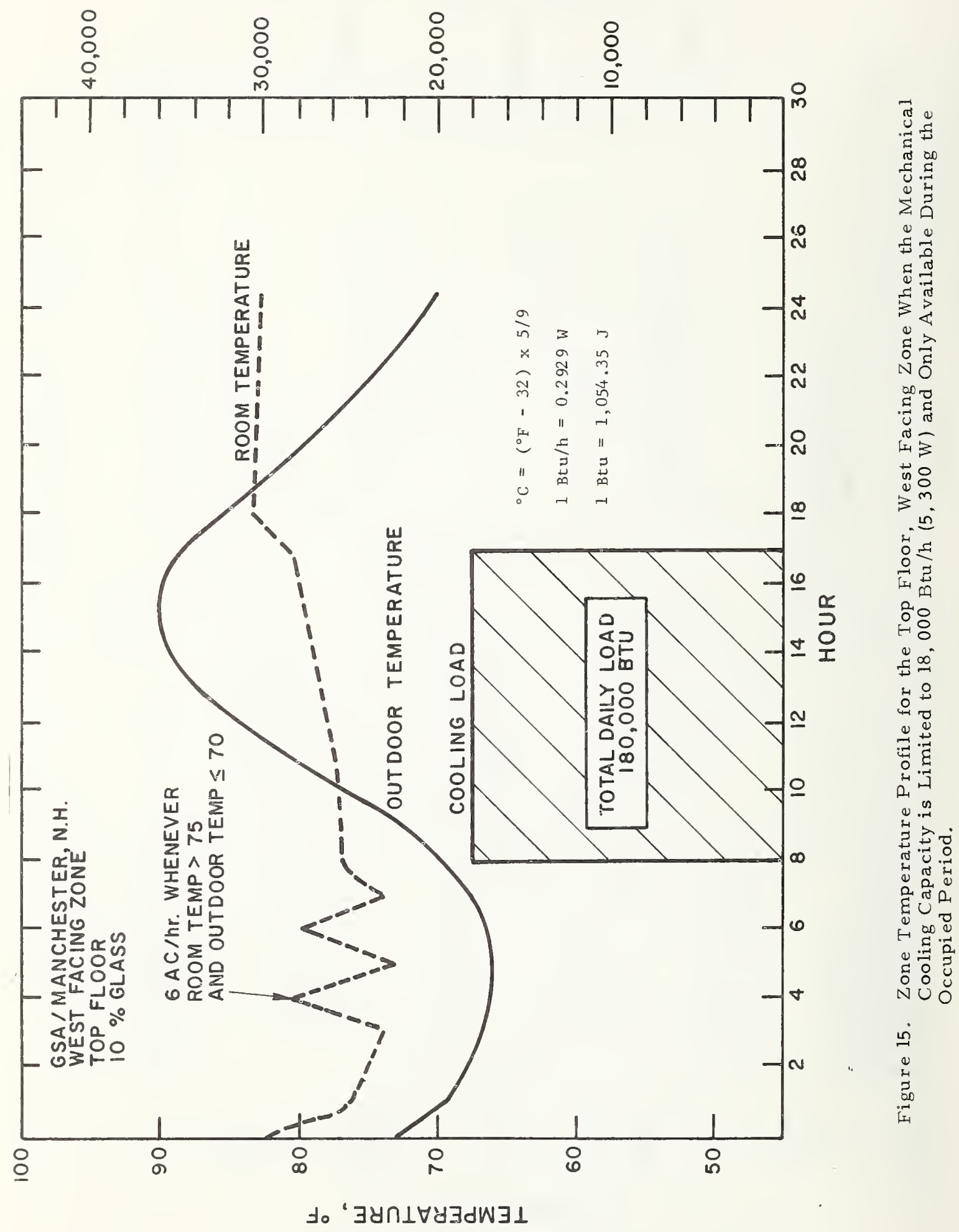




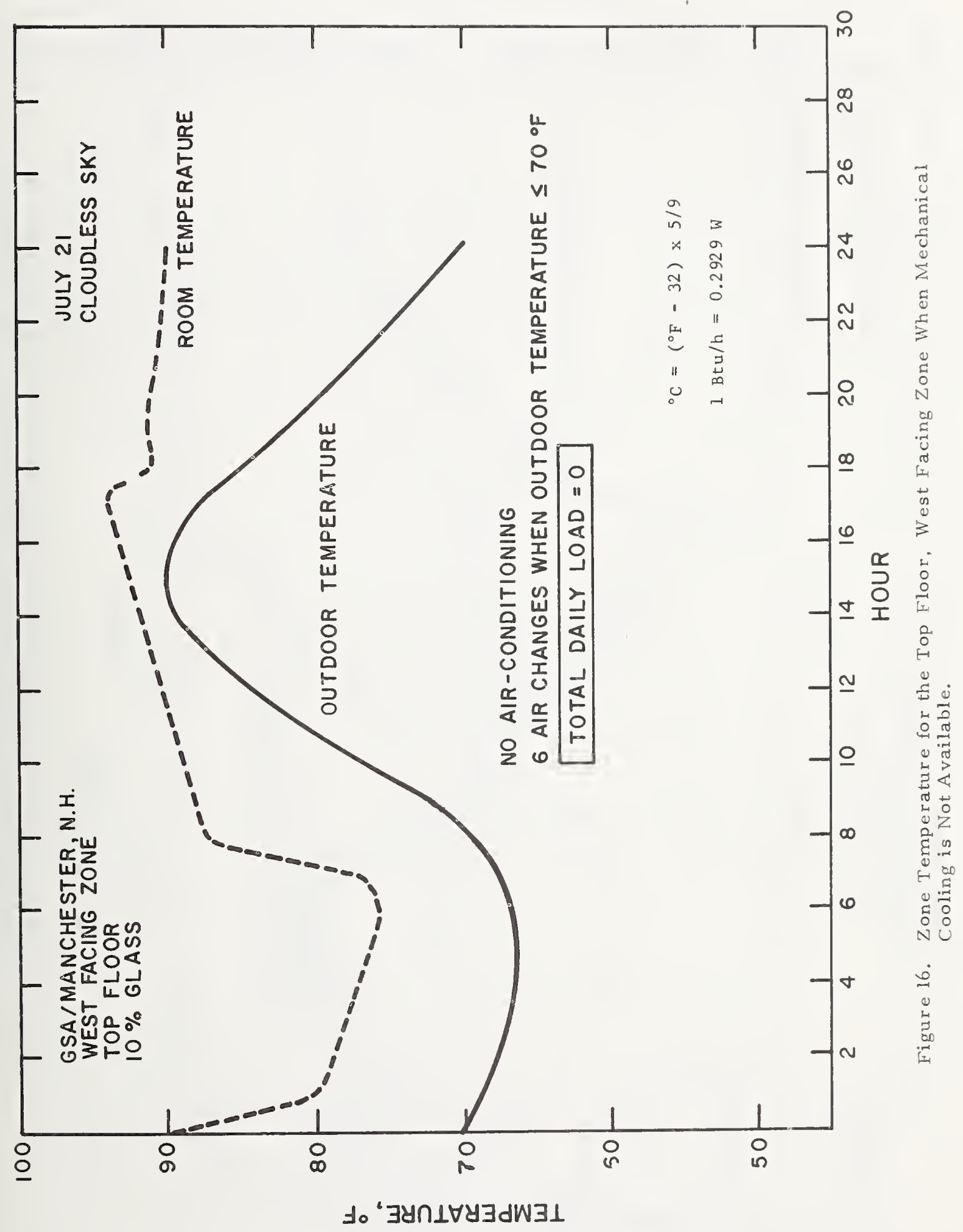


ป。 " $\exists y \cap \perp \forall y \exists d W \exists \perp$

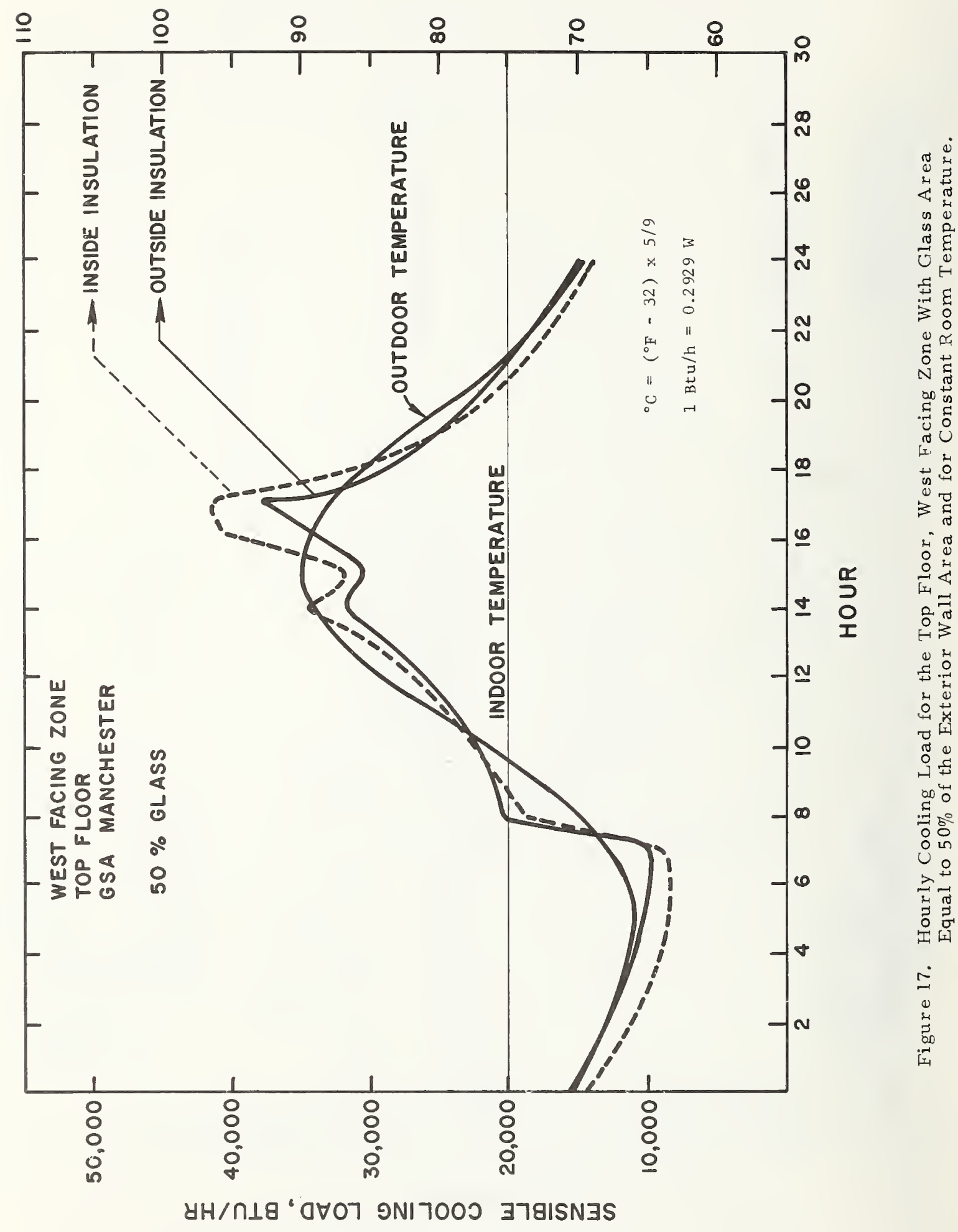


๖. ‘ $\exists ช ก \perp \forall \forall \exists d W \exists \perp$

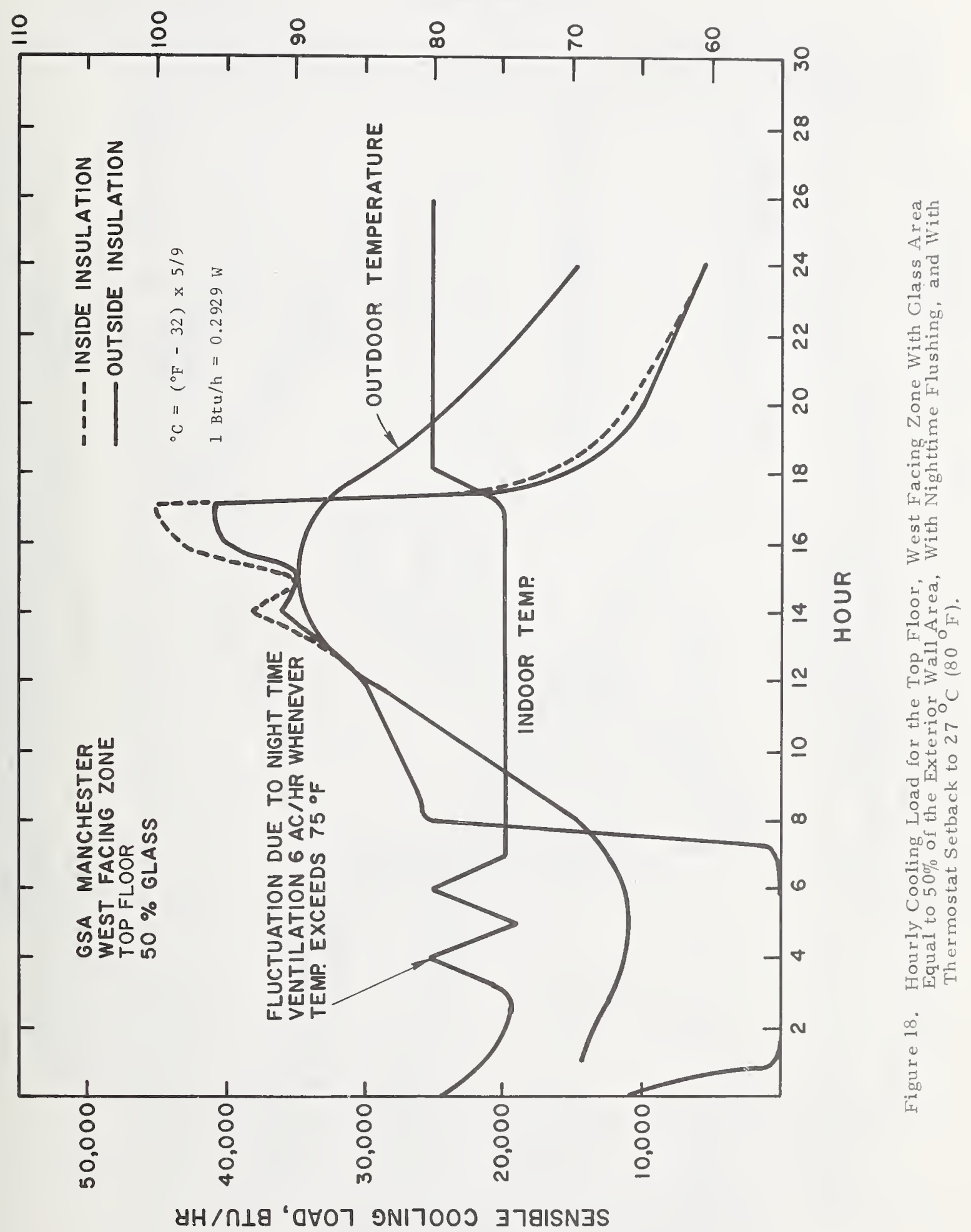




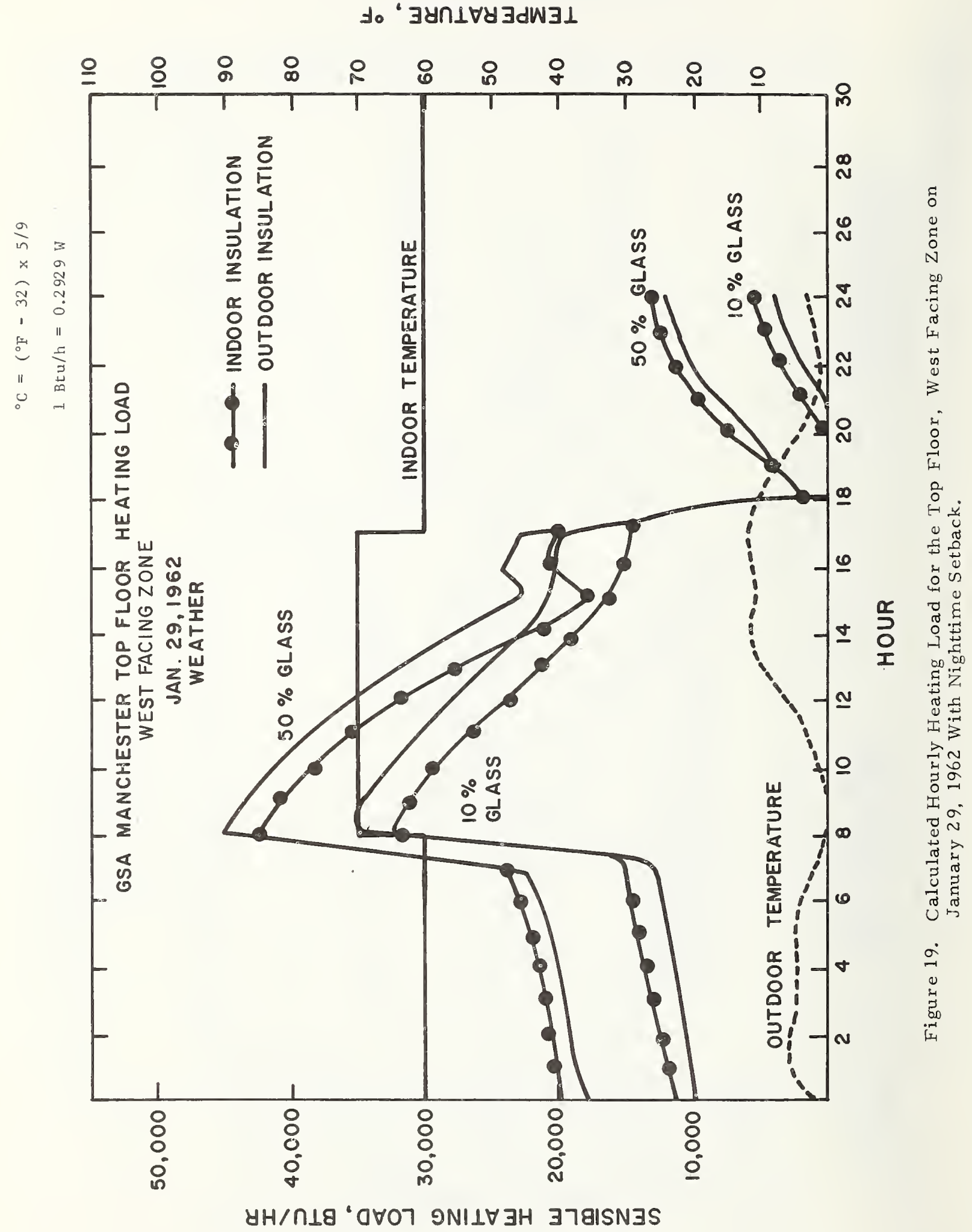


ป。' $\exists y \cap \perp \forall y \exists d W \exists \perp$

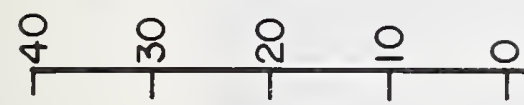

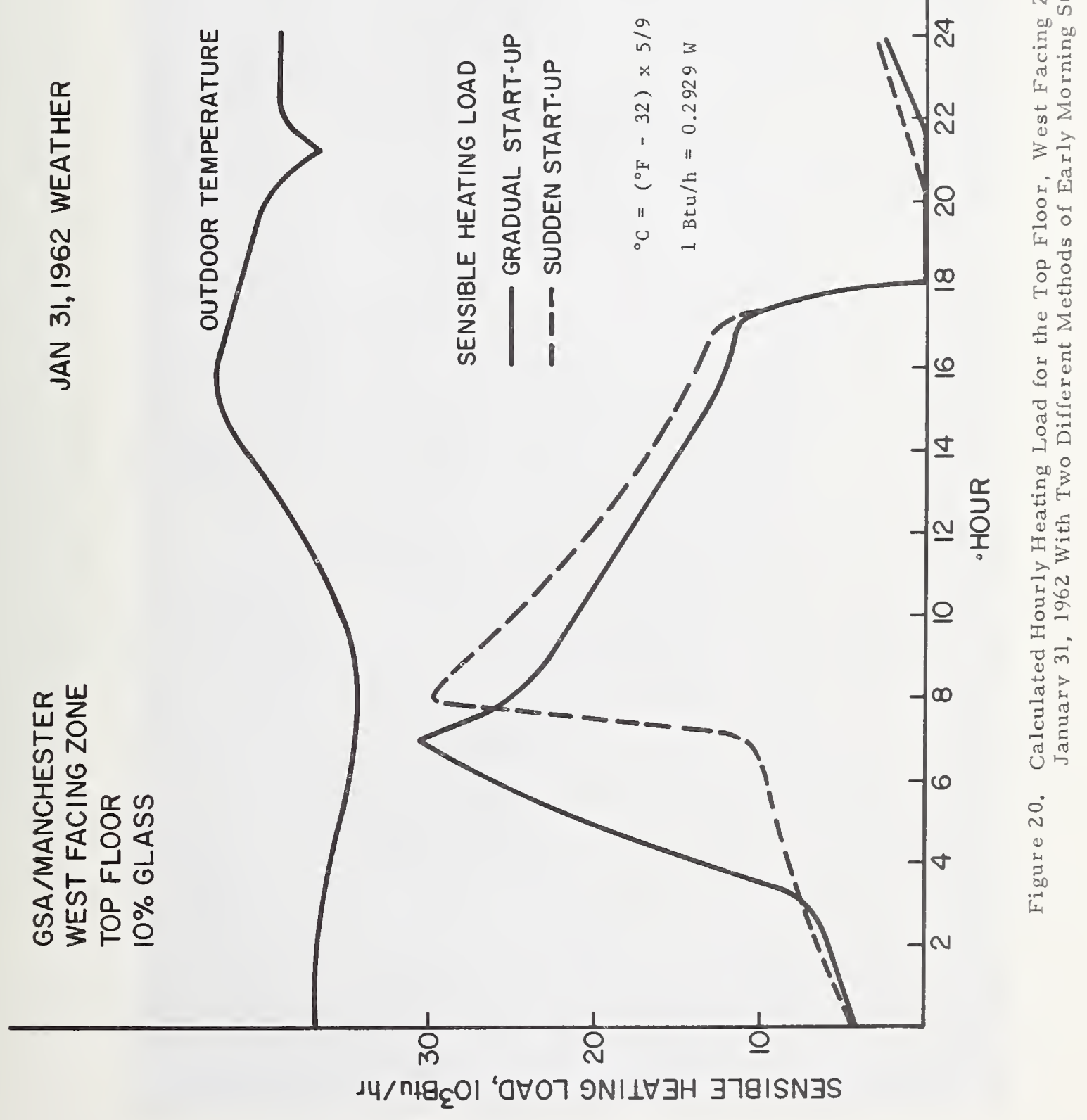




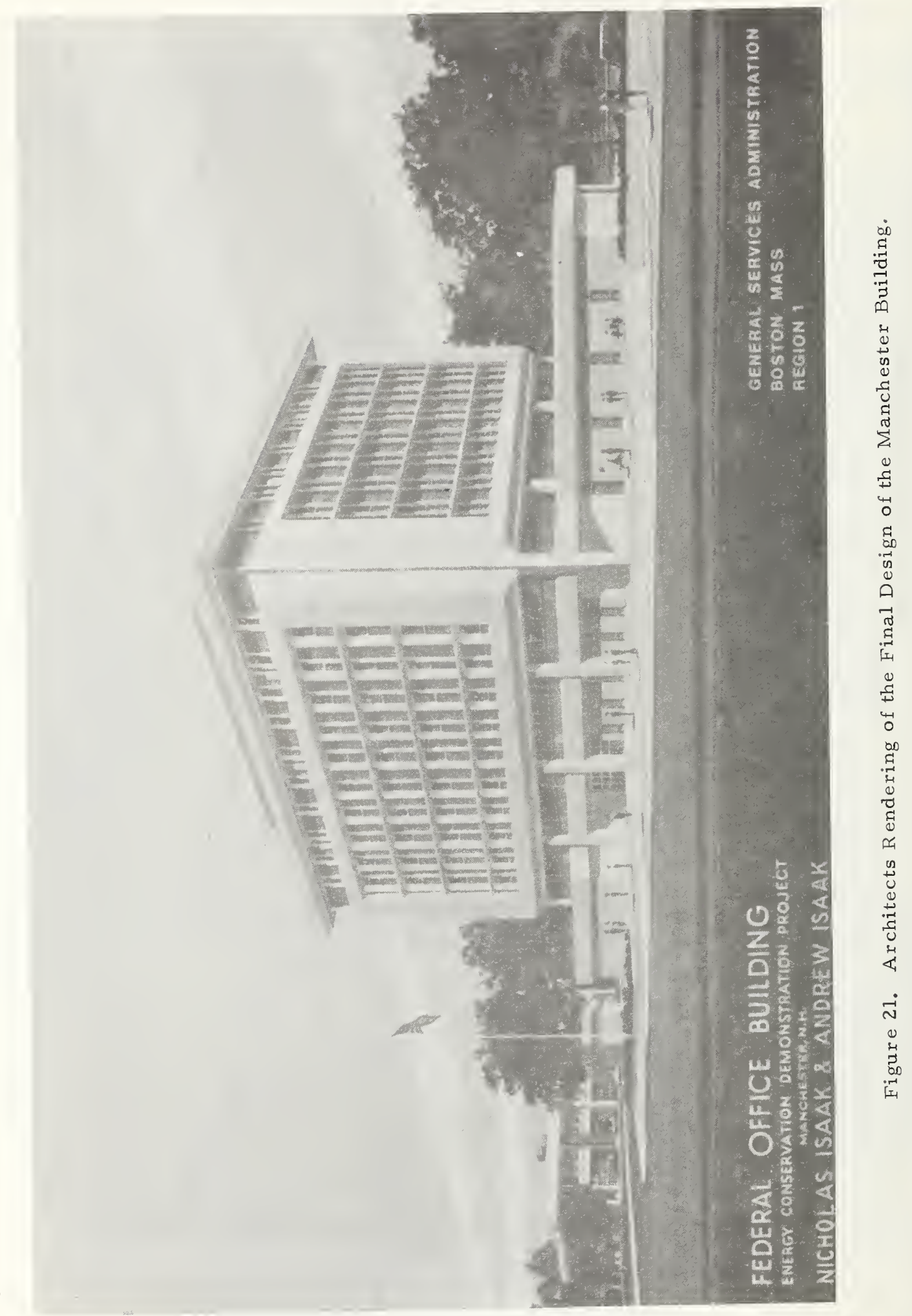




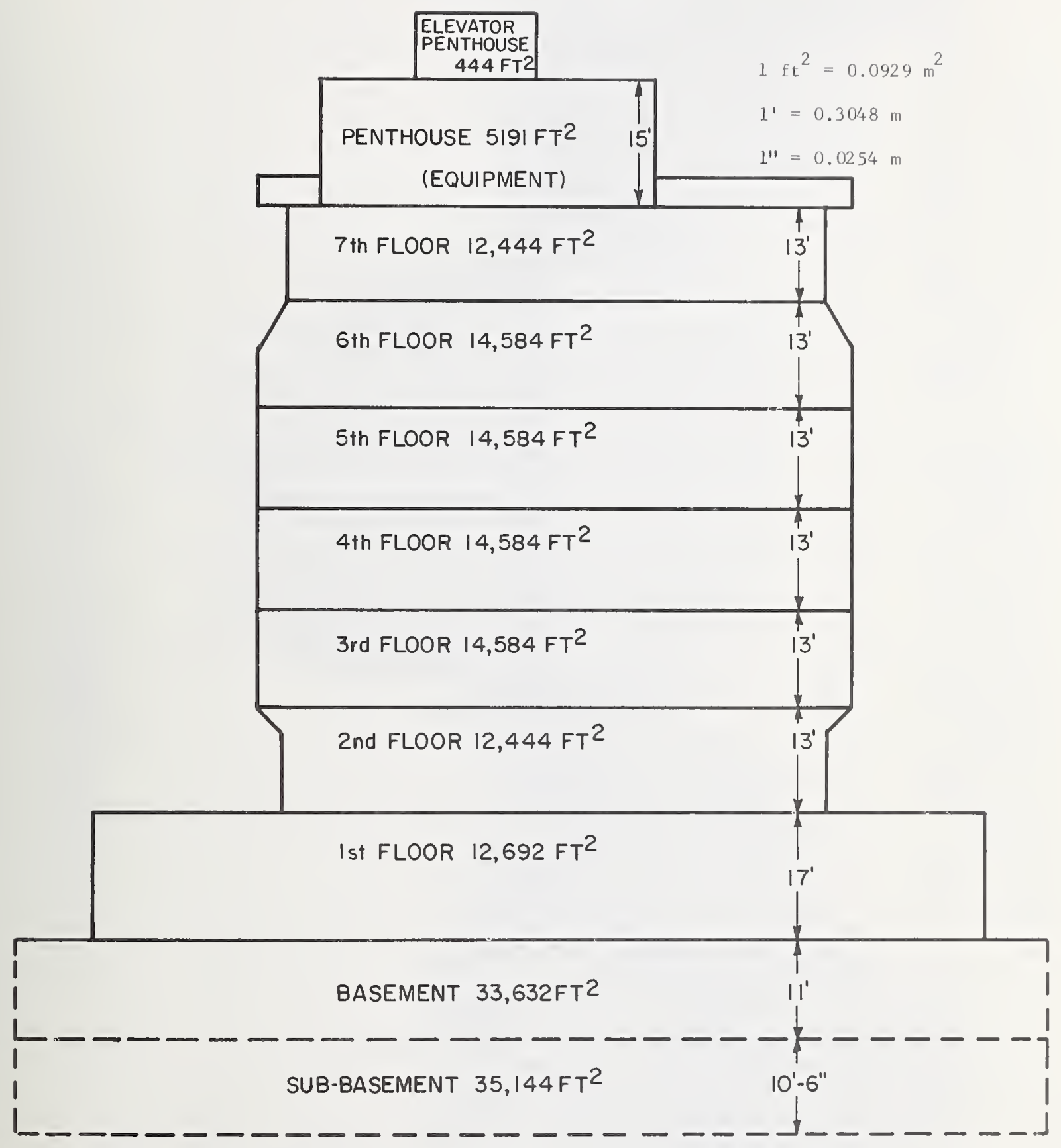

GSA/MANCHESTER FEDERAL OFFICE BUILDING

\section{GROSS FLOOR AREA $=170,327 \mathrm{FT}^{2}$}

Figure 22. Schematic of the Floor Areas for the Final Design of the Manchester Building. 


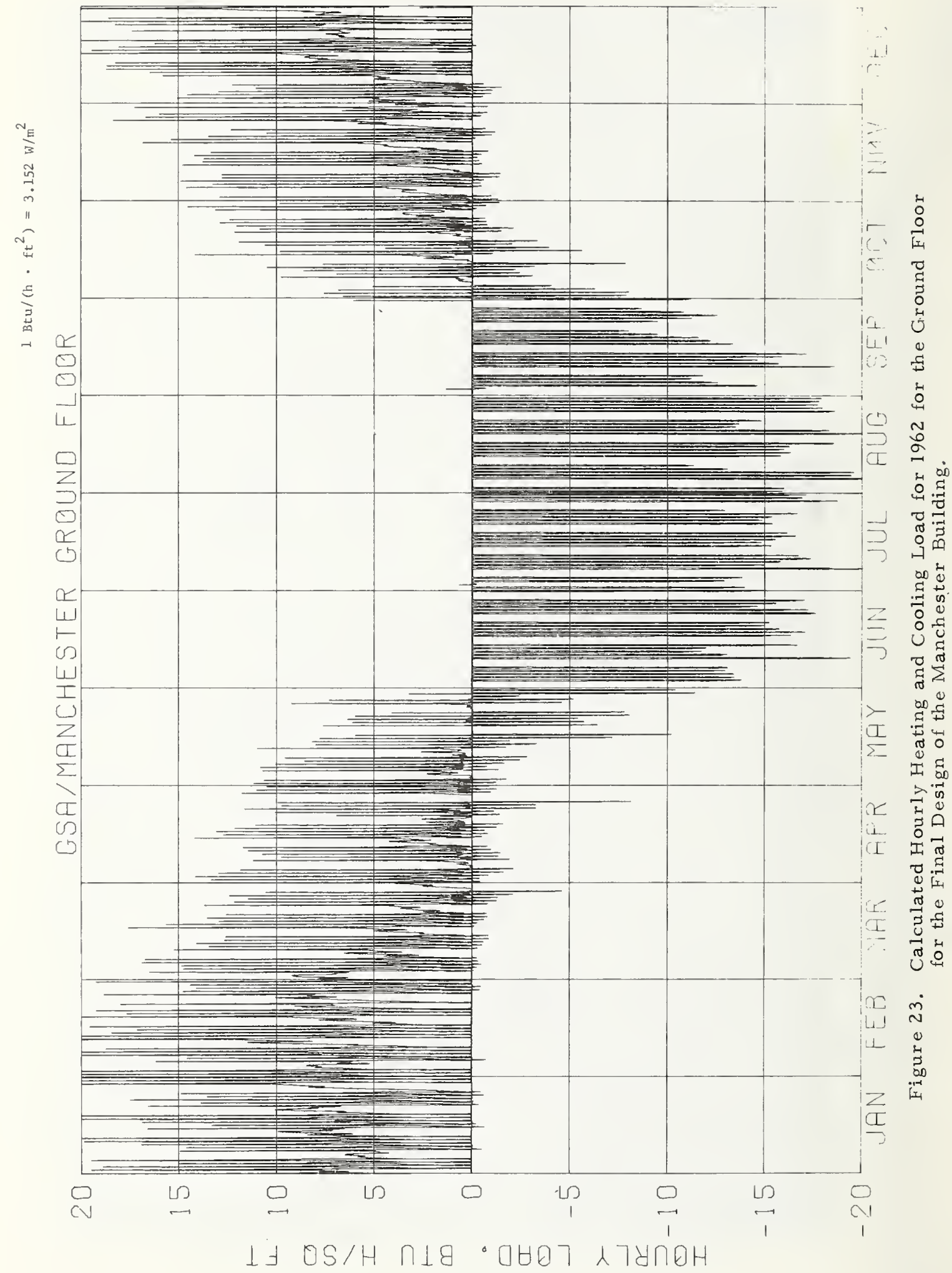




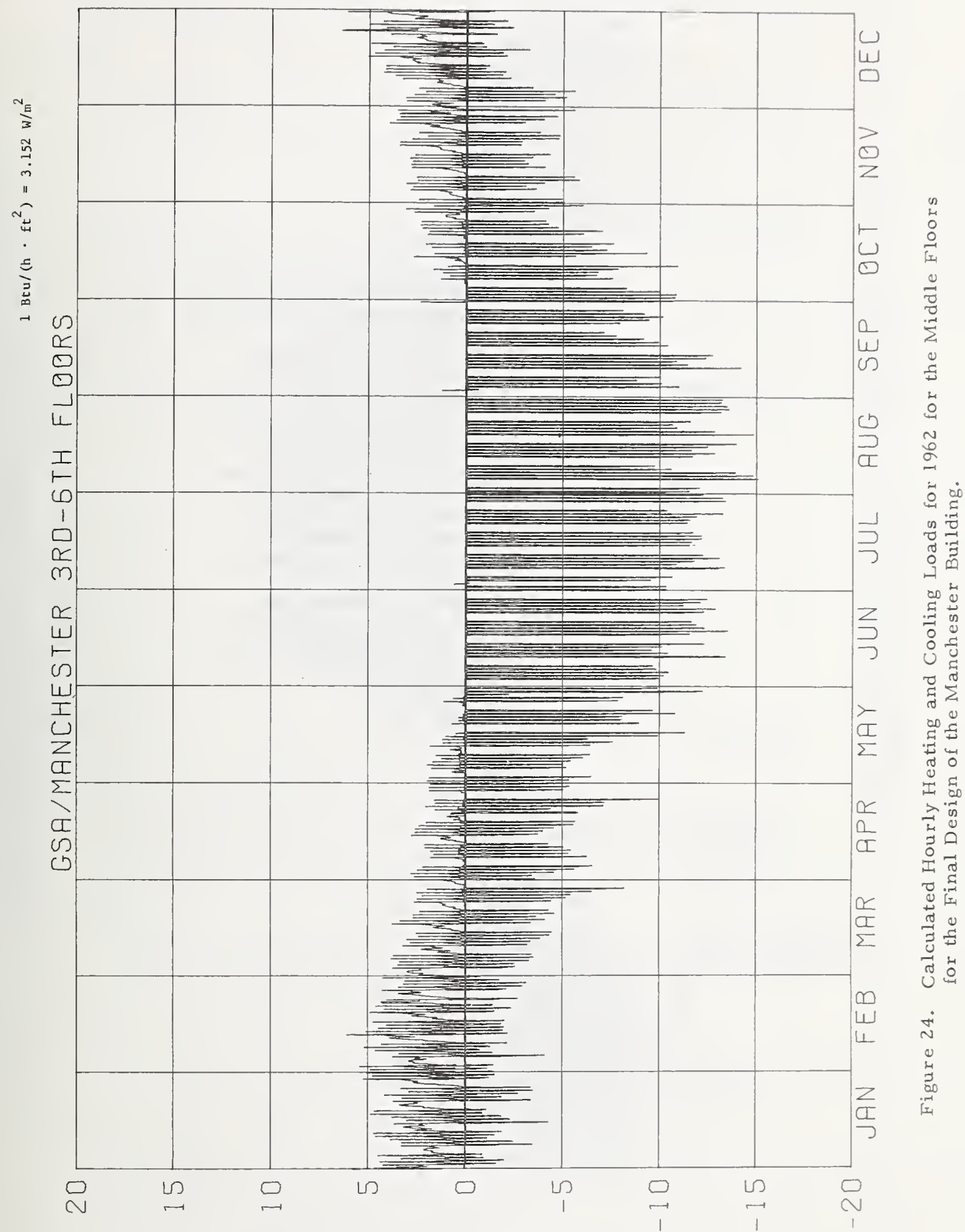

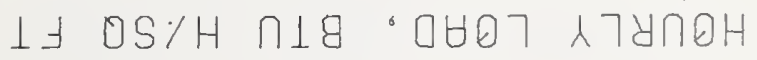




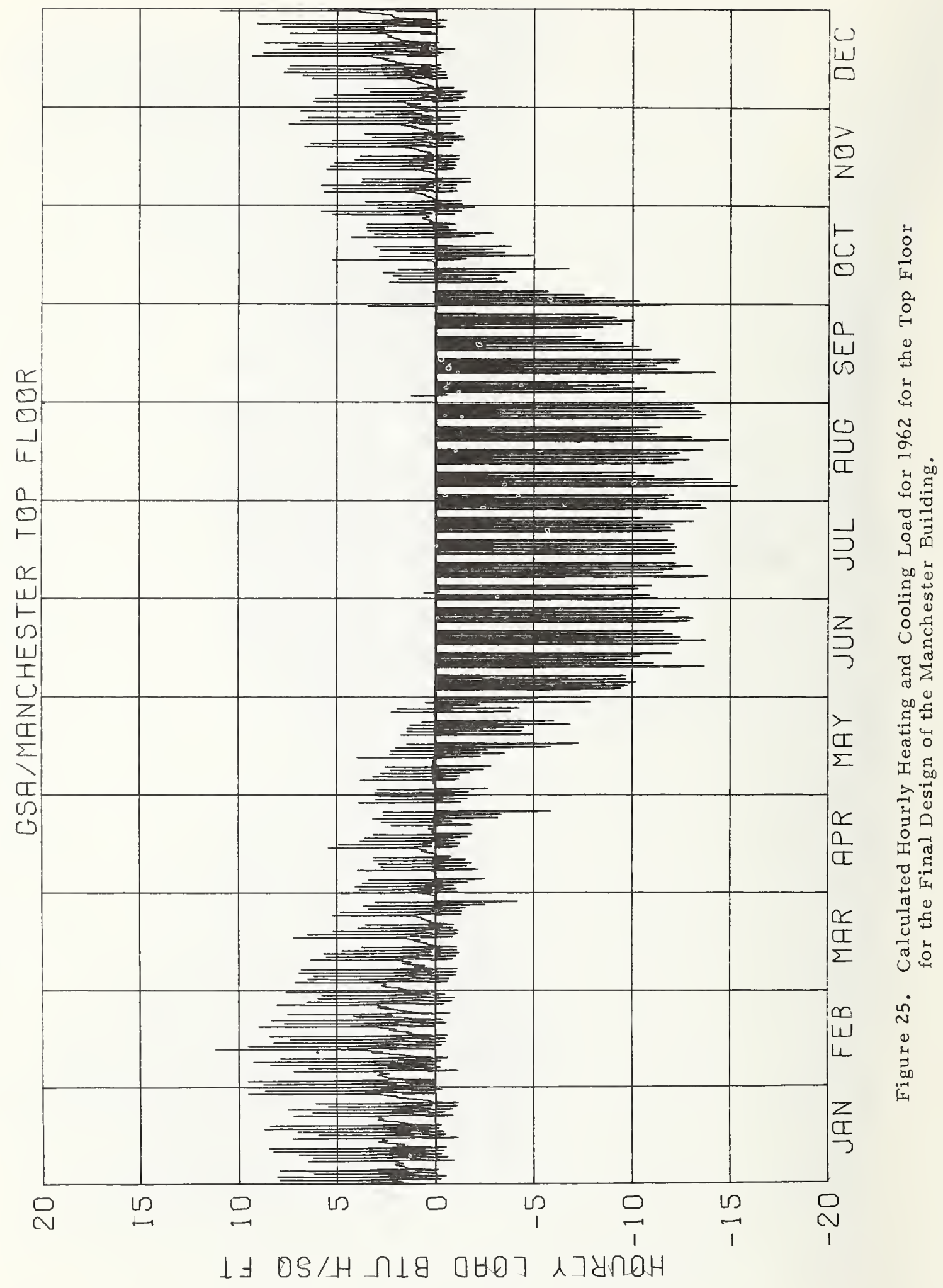




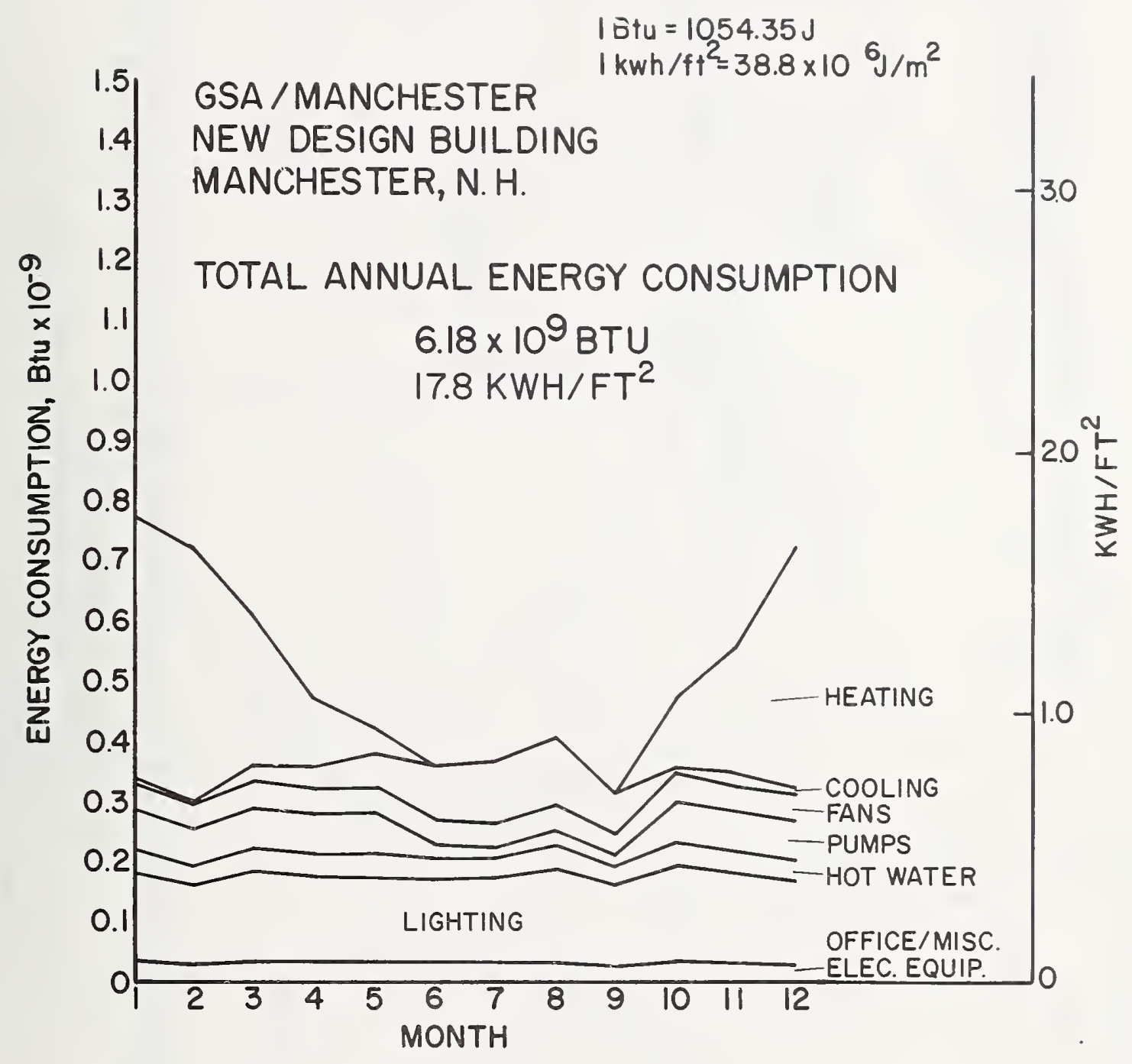

Figure 26. Predicted Monthly Profiles of Annual Energy Consumption for the Final Design Building. 


\section{ป。‘ $\exists บ \cap \perp \forall \mathcal{d} \exists d W \exists \perp$}

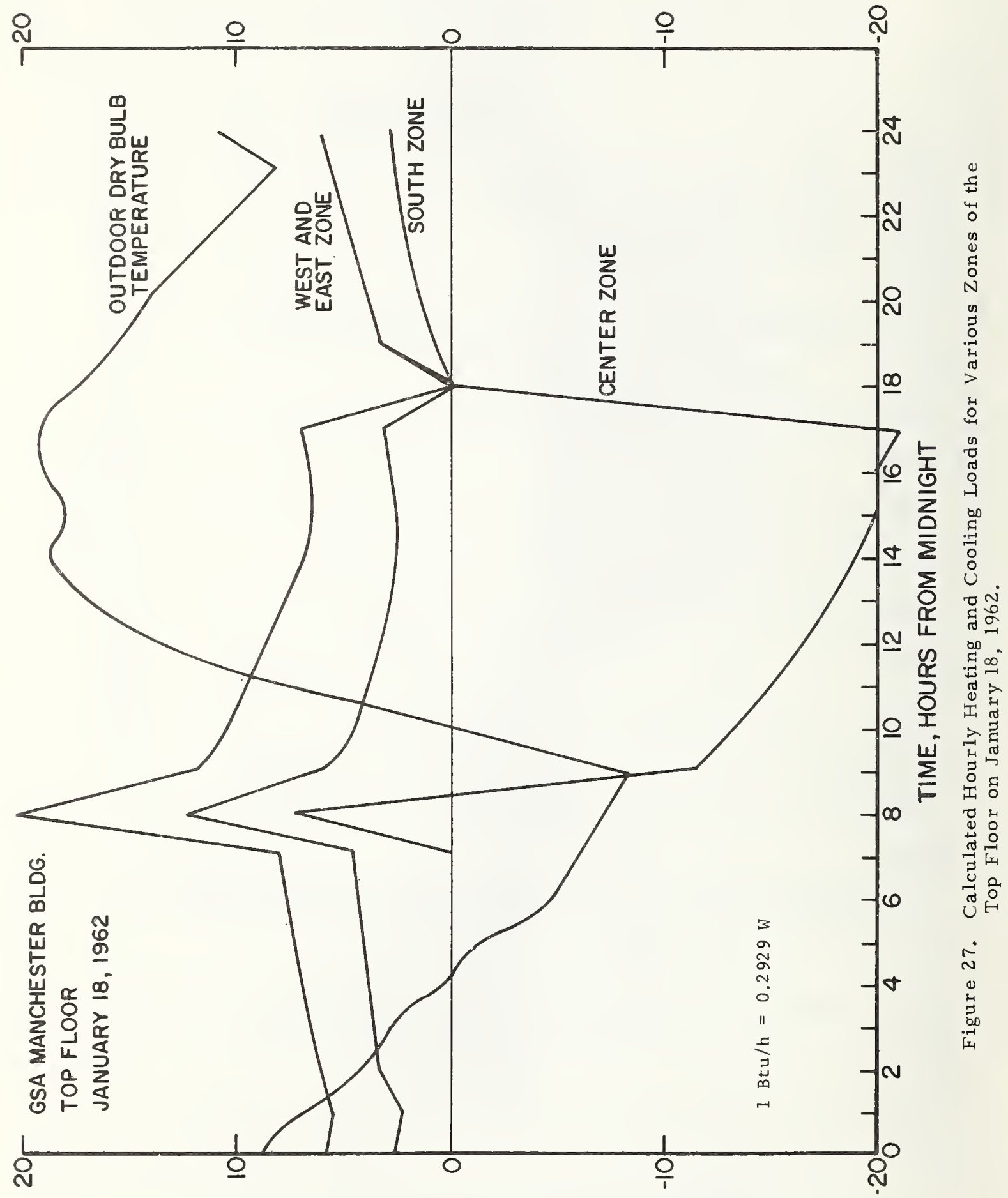




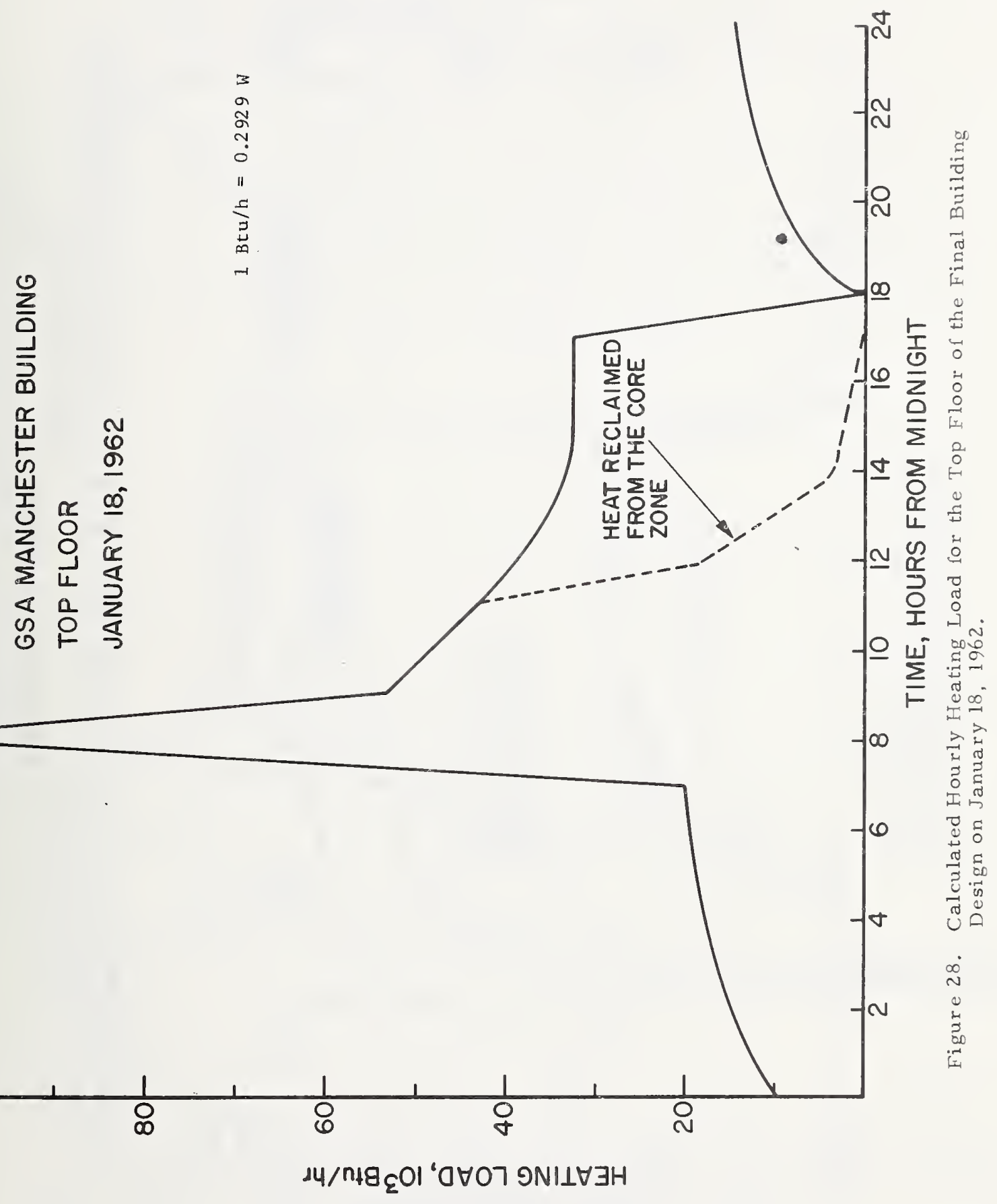




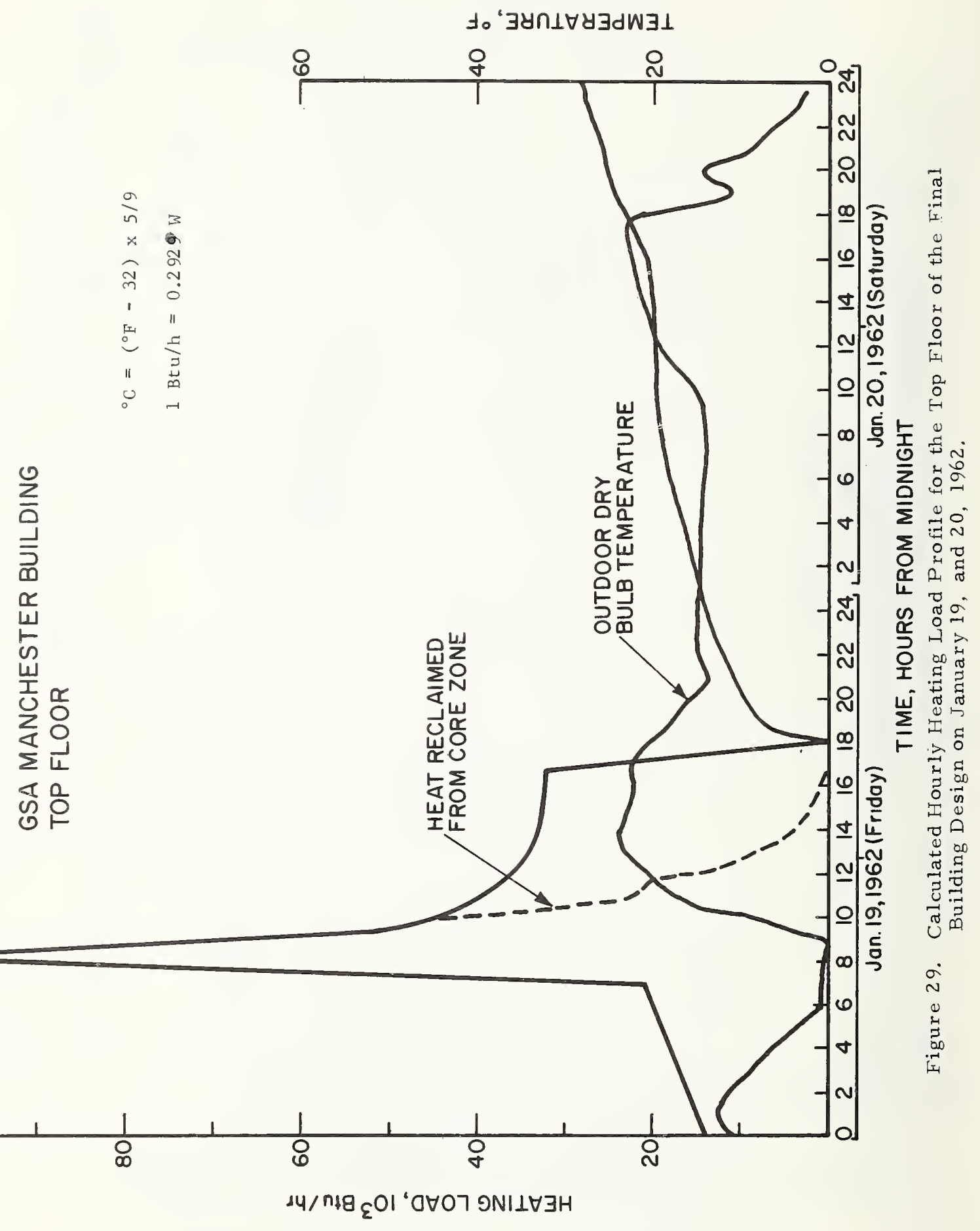




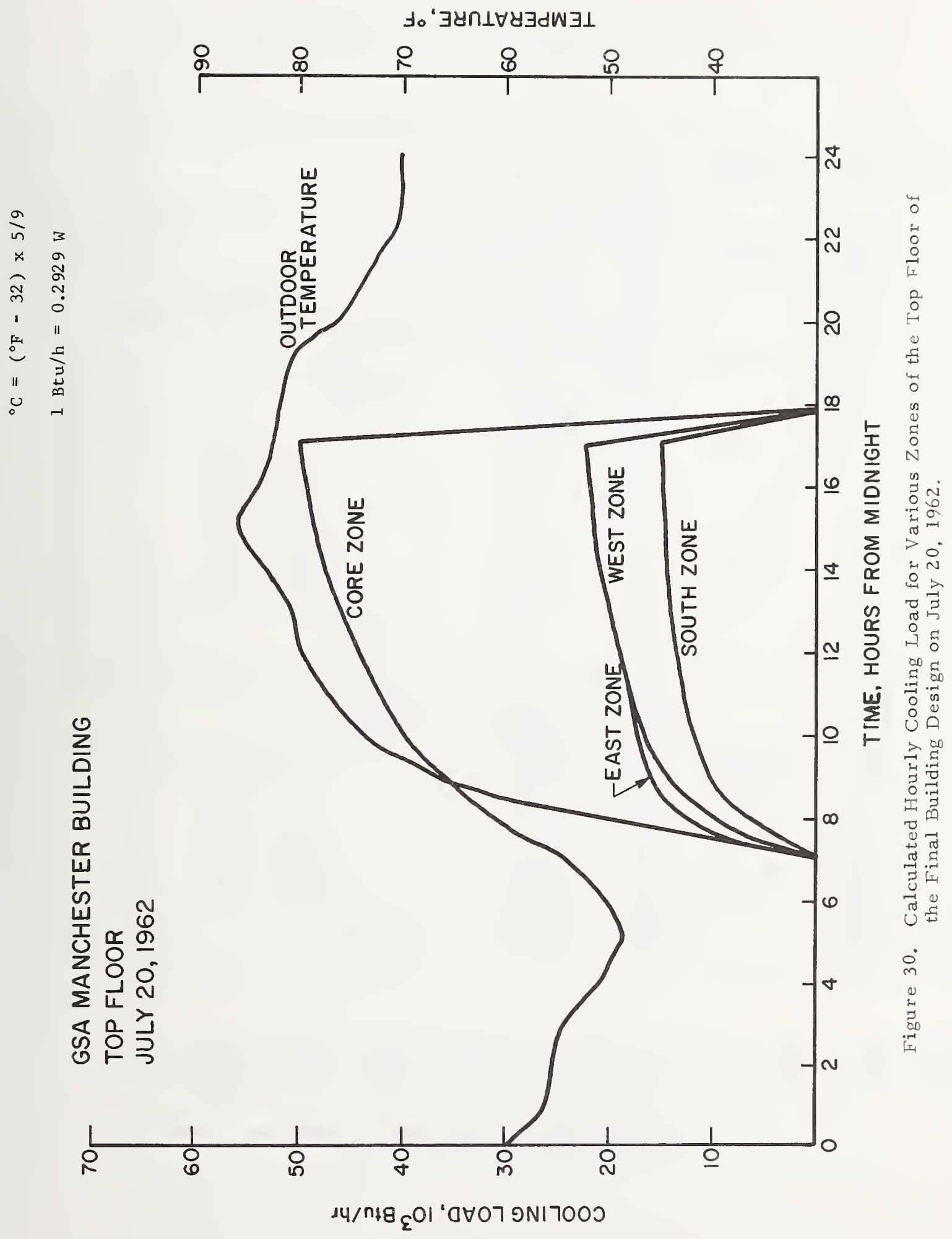




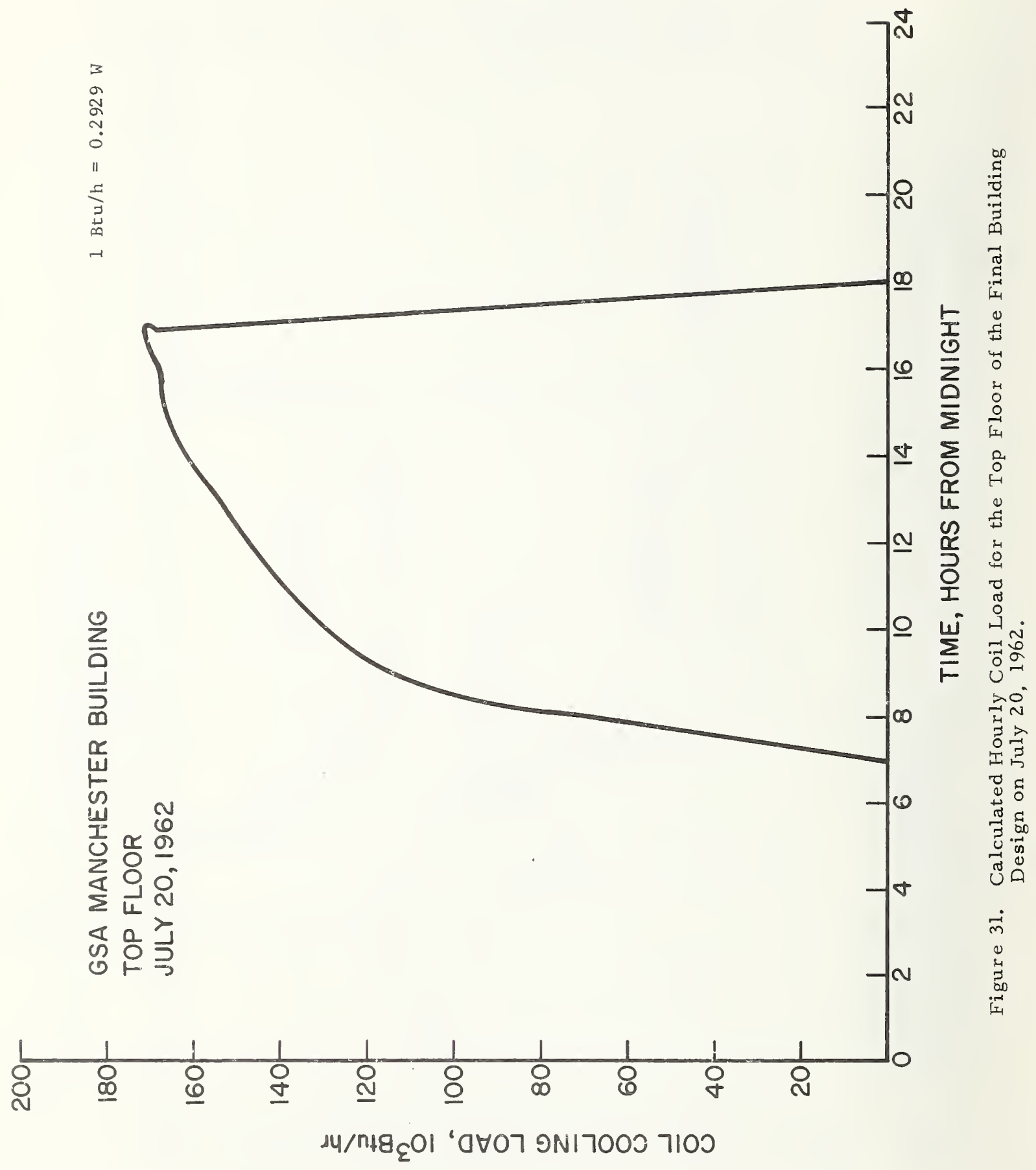


Table 1 Sample Tabular Data for Heating and Cooling Load From the Computer Print Out

MANCHESTER FNERGY COV. BLMF.-DIN IN MONTH $=1$ YEAR $=1$ 19K3

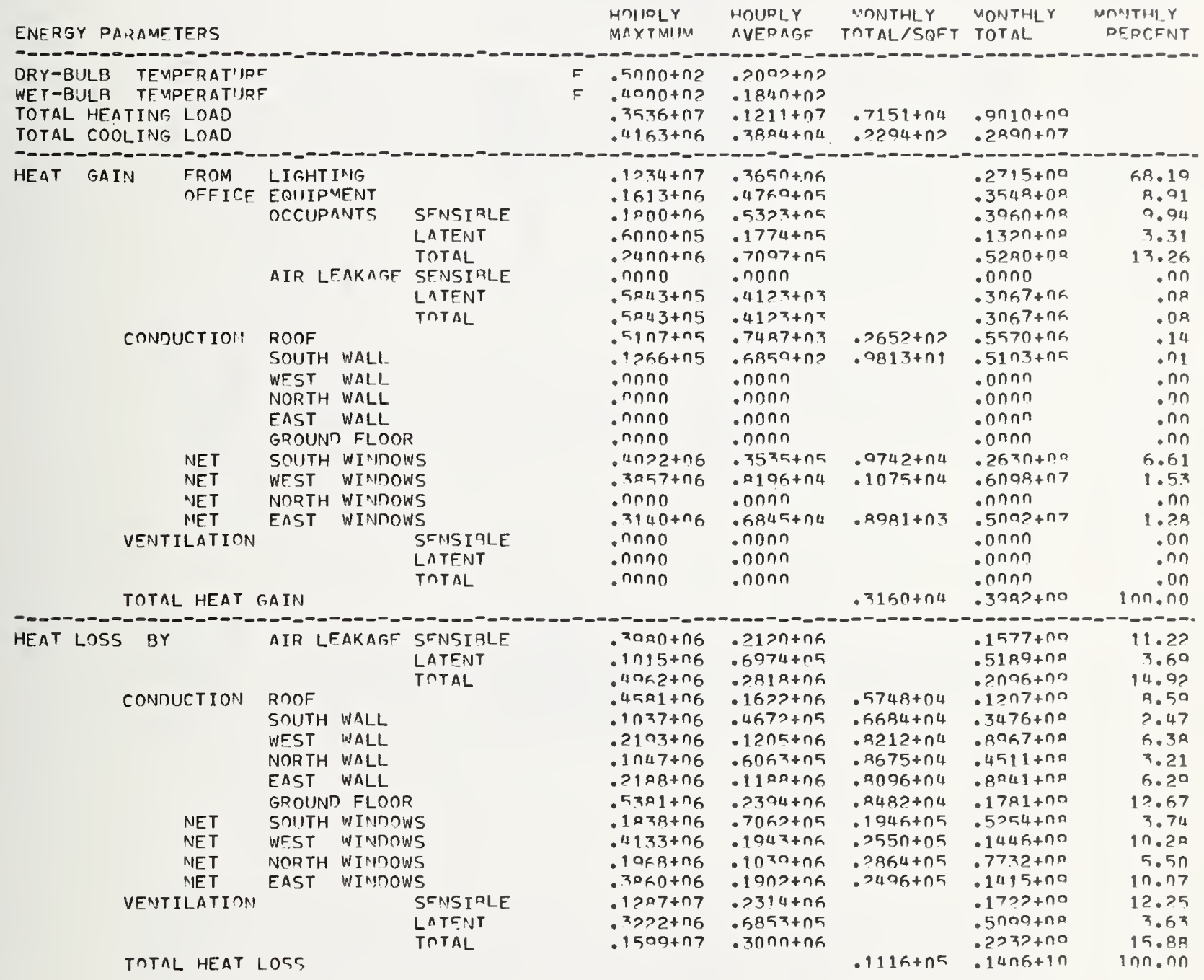

\footnotetext{
$1 \mathrm{Btu} / \mathrm{h}=0.2929 \mathrm{~W}$

$1 \mathrm{Btu}=1,054.35 \mathrm{~J}$

$1 \mathrm{Btu} / \mathrm{ft}^{2}=11,350 \mathrm{~J} / \mathrm{m}^{2}$
} 


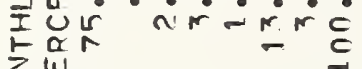
$\sum_{0}$

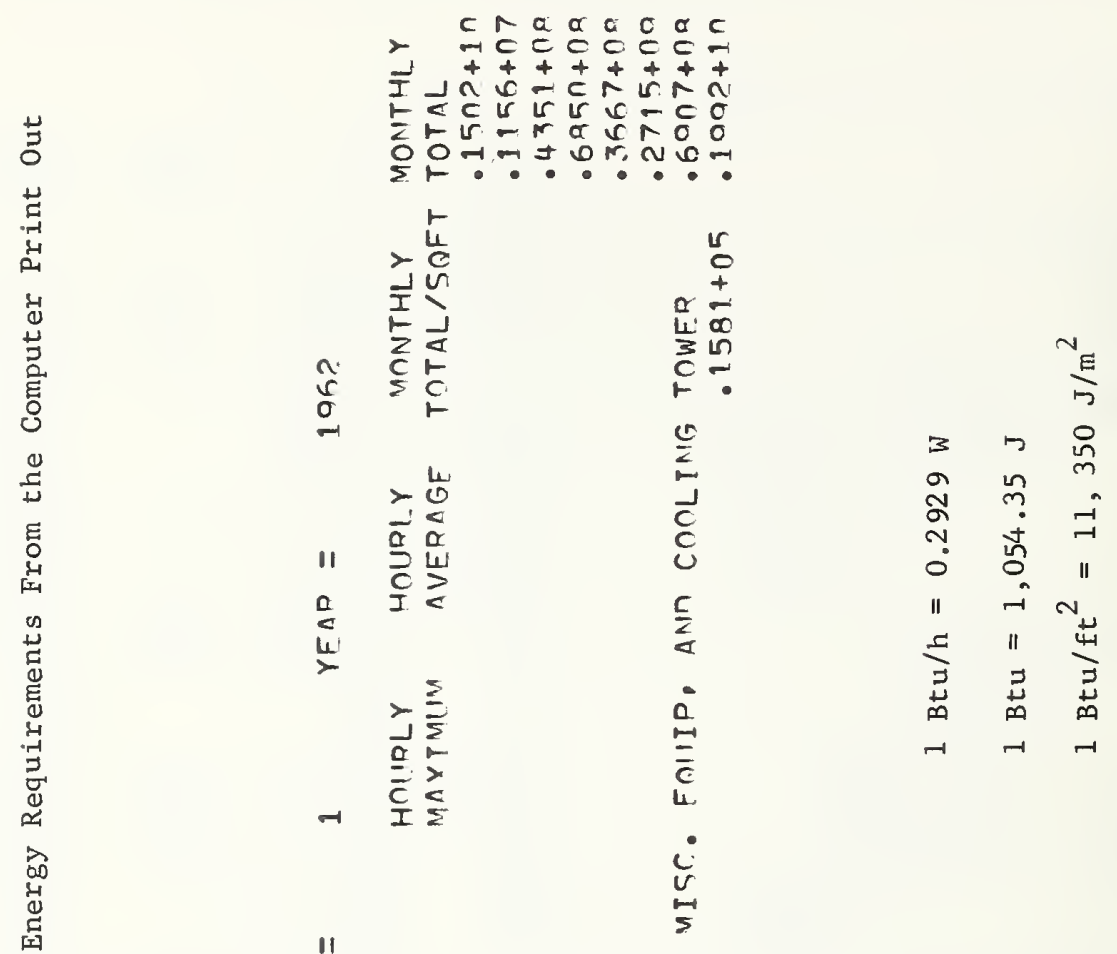

i

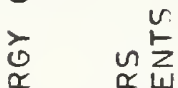

L 㟧岁

$\sum^{\prime} \quad \stackrel{\omega}{\alpha}$

品 $\quad \sum_{0}^{\infty}$

in

岌 万ঠ

$\sum_{\Sigma}^{5} \quad \begin{gathered}0 \\ \Sigma\end{gathered}$ 


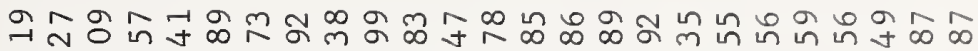

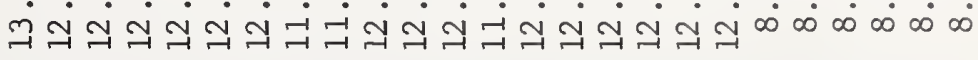

ข

开

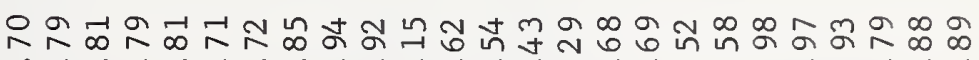

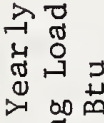
西要 ช. $+70 \rightarrow$

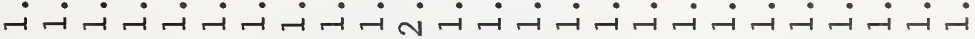

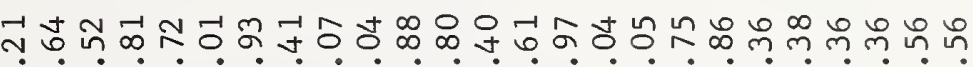

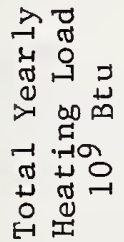

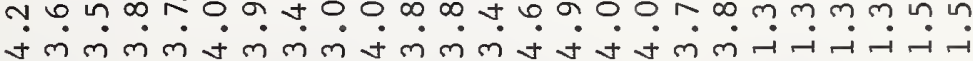

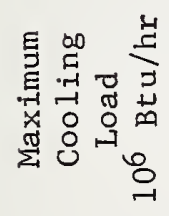

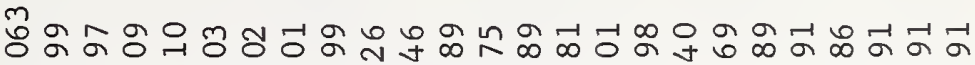

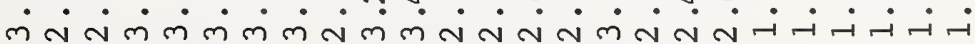

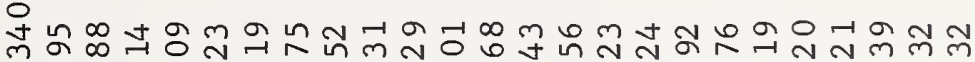

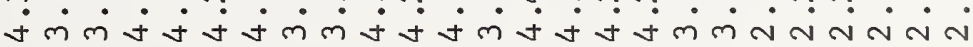


Table 4 The Effect of Insulation Position Within the Wall on Predicted Heating and Cooling Load*

\begin{tabular}{|c|c|c|c|c|c|}
\hline \multirow{3}{*}{$\frac{\text { Glass Area }}{\text { Wal1 Area }}$} & \multirow{3}{*}{$\begin{array}{l}\text { Nighttime } \\
\text { Setback }\end{array}$} & \multirow{3}{*}{$\begin{array}{c}\text { Direct Solar } \\
\text { Radiation On } \\
\text { Windows - March } \\
\text { Through September }\end{array}$} & \multicolumn{3}{|c|}{$\begin{array}{l}\text { Insulation is Moved } \\
\text { From Inside to Outside }\end{array}$} \\
\hline & & & Heating & Heating & Cooling \\
\hline & & & Maximum & Total & Maximum \\
\hline $50 \%$ & yes & yes & - & - & +8.3 \\
\hline $50 \%$ & no & no & - & -- & +1.5 \\
\hline $50 \%$ & no & yes & -3.8 & +1.5 & +9.3 \\
\hline $10 \%$ & yes & yes & - & - & +4.6 \\
\hline $10 \%$ & no & no & - & - & +2.8 \\
\hline $10 \%$ & no & yes & -6.0 & +3.1 & +7.5 \\
\hline
\end{tabular}

*

West zone, top floor, 1/4 air change/hr based on the west zone volume only. A sample cooling load calculation was done for each of the other three exterior zones and similar results were obtained. 
Table 5 Construction Data for the Final. Building Design

$\begin{array}{llllll}\text { L } & \text { K } & \text { P } & \text { C } & \text { RES }\end{array}$

Roof

Inside Surface

1.74

12 Inch C.M.U.

1.0

1.0

140.0

0.2

6 Inch Insulation

0.5

0.025

5.7

0.2

Composite Roofing

.0313

.67

70.0

0.35

Exterior Wall

Inside Surface

1/2 Inch Gypsum Board

0.047

0.47

50.0

0.2

$3 / 4$ Inch Furring

1.0

1.0

140.0

1.02

12 Inch C.M.U.

0.25

0.025

2.0

0.2

3 Inch Insulation

0.0417

0.24

78.0

0.2

Pre-Casting Facing

0.0417

Ground Floor

Inside Surface

Concrete Fill

0.33

1.0

140.0

0.74

Insulation

0.33

0.025

2.0

0.2

Waffle Slab

0.33

1.0

140.0

0.2

0.2

Floor/Ceiling

Inside Surface

0.74

3 Inch Steel Deck

0.125

26.0

490.0

0.11

2-1/2 Inch Concrete

0.2083

1.0

140.0

0.20

Inside Surface 


\section{Table 5 - Continued}

L

K

P

C

RES

Partition Wall

Inside Surface

0.685

1/2 Inch Gypsum Board

0.042

0.42

50.0

0.2

Air Space

0.042

0.42

50.0

0.2

Inside Surface

0.685

L: Thickness, ft

$\mathrm{K}$ : Thermal Conductivity, Btu/(h $\left.\cdot \mathrm{ft} \cdot{ }^{\circ} \mathrm{F}\right)$

$\mathrm{P}:$ Density, $1 \mathrm{~b} / \mathrm{ft} \mathrm{t}^{3}$

$\mathrm{C}:$ Specific Heat, Btu/ $1 \mathrm{~b}^{\circ} \mathrm{F}$

$\mathrm{R}$ : Therma1 Resistance, (h $\left.\cdot \mathrm{ft}^{2} \cdot{ }^{\circ} \mathrm{F}\right) / \mathrm{Btu}$
$1 \mathrm{ft}=0.3048 \mathrm{~m}$

$1 \mathrm{Btu} /\left(\mathrm{h} \cdot \mathrm{ft} \cdot{ }^{\circ} \mathrm{F}\right)=0.17296 \mathrm{~W} /\left(\mathrm{m} \cdot{ }^{\circ} \mathrm{C}\right)$

$11 \mathrm{~b}^{\prime} \mathrm{ft}^{3}=16.02 \mathrm{~kg} / \mathrm{m}^{3}$

$1 \mathrm{Btu} /\left(1 \mathrm{~b}{ }^{\circ} \mathrm{f}=4,186.8 \mathrm{~J} / \mathrm{kg}^{\circ} \mathrm{K}\right.$

$1\left(\mathrm{~h} \cdot \mathrm{ft}^{2} \cdot{ }^{\circ} \mathrm{F}\right) / \mathrm{Btu}=0.176\left(\mathrm{~m}^{2} \cdot{ }^{\circ} \mathrm{C}\right) / \mathrm{W}$ 
Table 6 Miscellaneous Operating Data Assumed for the Final Building Design

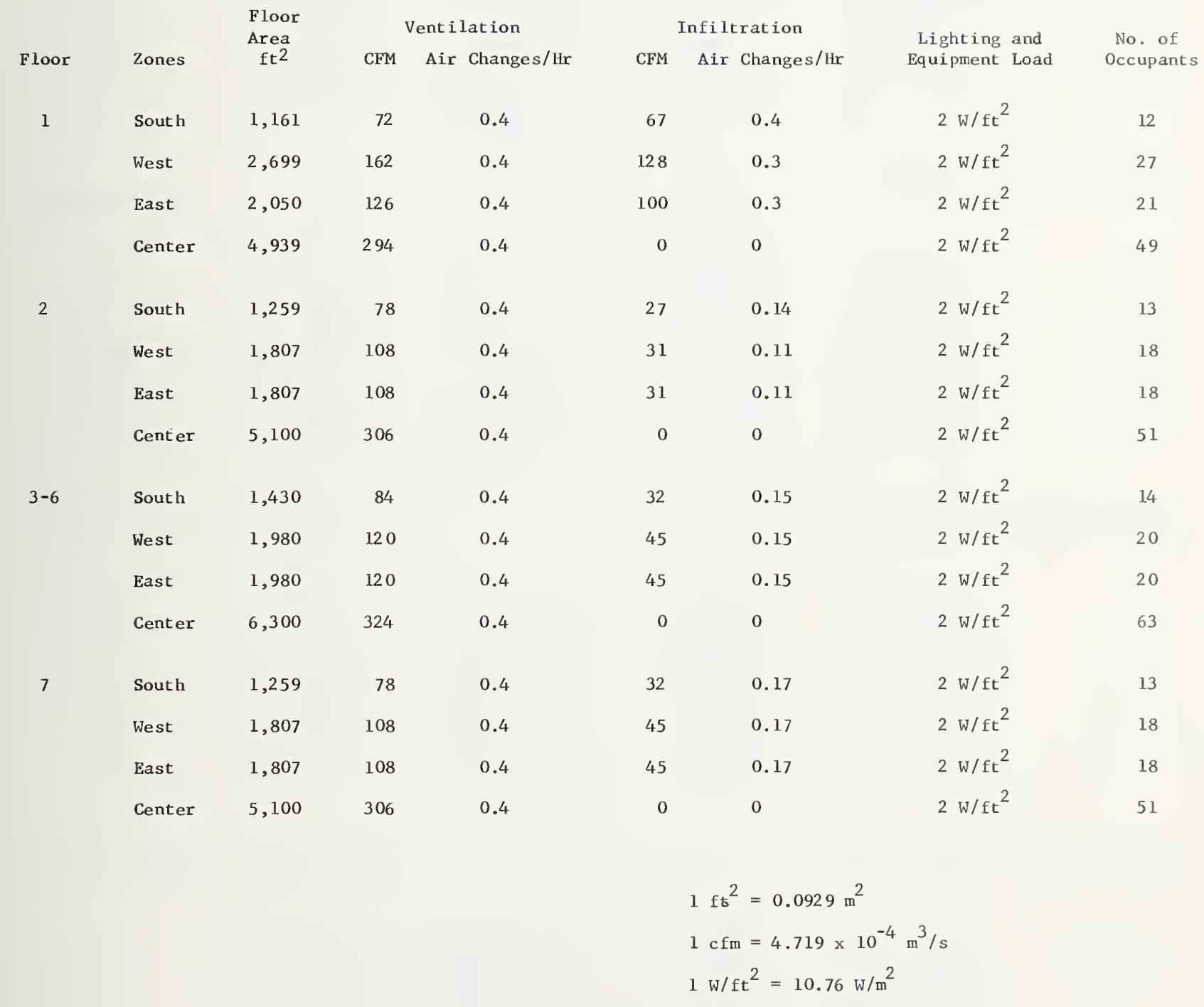


Table 7 Zone Configuration Data for the Final Building Design

\begin{tabular}{|c|c|c|c|c|}
\hline Surface & Type & $\underset{\mathrm{ft}^{2}}{\text { Area }}$ & Orientation & $\begin{array}{l}\text { Absorption } \\
\text { Coefficient }\end{array}$ \\
\hline
\end{tabular}

Ground Floor, South Zone

$\begin{array}{llrlll}1 & \text { Ceiling } & 1,161.0 & - & 0 & 0 \\ 2 & \text { Ext. Wall } & 1,060.0 & \text { SW } & 0 & 0.9 \\ 3 & \text { Window } & 130.0 & \text { SW } & 0.56 & 0 \\ 4 & \text { Int. Wa11 } & 255.0 & \text { N } & 0 & 0 \\ 5 & \text { Int. Wall } & 935.0 & \text { NE } & 0 & 0 \\ 6 & \text { Int. Wall } & 360.0 & \text { NE } & 0 & 0 \\ 7 & \text { Floor } & 1,161.0 & - & 0 & \end{array}$

Ground Floor, West Zone

$\begin{array}{llrrll}1 & \text { Ceiling } & 2,699.0 & - & 0 & 0 \\ 2 & \text { Int. Wa11 } & 255.0 & \mathrm{~S} & 0 & 0 \\ 3 & \text { Ext. Wa11 } & 2,611.0 & \text { W } & 0 & 0.9 \\ 4 & \text { Window } & 520.0 & \text { W } & 0.56 & 0.9 \\ 5 & \text { Ext. Wa11 } & 467.5 & \text { N } & 0 & 0.9 \\ 6 & \text { Ext. Wall } & 940.1 & \text { E } & 0 & 0 \\ 7 & \text { Int. Wall } & 1,955.0 & \text { E } & 0 & 0\end{array}$

Ground Floor, East Zone

$\begin{array}{rrrlll}1 & \text { Ceiling } & 2,050.0 & - & 0 & 0 \\ 2 & \text { Int.Wa11 } & 360.4 & \text { SW } & 0 & 0 \\ 3 & \text { Int. Wall } & 2,550.0 & \text { W } & 0 & 0 \\ 4 & \text { Int. Wall } & 255.0 & \mathrm{~N} & 0 & 0.9 \\ 5 & \text { Ext.Wa11 } & 1,153.0 & \mathrm{E} & 0 & 0 \\ 6 & \text { Window } & 312.0 & \mathrm{E} & 0.56 & 0\end{array}$

Ground Floor, Center Zone

$\begin{array}{llrlll}1 & \text { Ceiling } & 4,939.0 & - & 0 & 0 \\ 2 & \text { Int.Wa11 } & 935.0 & \text { SW } & 0 & 0 \\ 3 & \text { Int. Wa11 } & 1,904.0 & \text { W } & 0 & 0 \\ 4 & \text { Int. Wall } & 586.5 & \text { N } & 0 & 0 \\ 5 & \text { Int. Wall } & 2,550.0 & \text { E } & 0 & 0 \\ 6 & \text { Floor } & 4,939.0 & - & 0 & \end{array}$


Table 7 - Continued

\begin{tabular}{|c|c|c|c|c|c|}
\hline Surface & Type & $\begin{array}{l}\text { Area } \\
\mathrm{ft}^{2}\end{array}$ & Orientation & $\begin{array}{c}\text { Shading } \\
\text { Coefficient }\end{array}$ & $\begin{array}{l}\text { Absorption } \\
\text { Coefficient }\end{array}$ \\
\hline
\end{tabular}

3rd-6th Floor, South Zone

$\begin{array}{llrlll}1 & \text { Ceiling } & 1,430.0 & - & 0 & 0 \\ 2 & \text { Ext. Wall } & 1,420.0 & \mathrm{~S} & 0 & 0.9 \\ 3 & \text { Window } & 49.0 & \mathrm{~S} & 0.56 & 0 \\ 4 & \text { Int. Wall } & 275.6 & \mathrm{NW} & 0 & 0 \\ 5 & \text { Int. Wall } & 1,079.0 & \mathrm{~N} & 0 & 0 \\ 6 & \text { Int. Wall } & 275.6 & \mathrm{NE} & 0 & 0 \\ 7 & \text { Floor } & 1,430.0 & - & 0 & 0\end{array}$

3rd-6th Floor, West Zone

$\begin{array}{llrlll}1 & \text { Ceiling } & 1,980.0 & - & 0 & 0 \\ 2 & \text { Int. Wall } & 275.6 & \text { SE } & 0 & 0 \\ 3 & \text { Ext. Wall } & 1,659.0 & \text { W } & 0 & 0.9 \\ 4 & \text { Window } & 70.0 & \text { W } & 0.56 & 0 \\ 5 & \text { Ext. Wall } & 510.0 & \text { N } & 0 & 0.9 \\ 6 & \text { Int. Wall } & 1,339.0 & \text { E } & 0 & 0 \\ 7 & \text { Floor } & 1,980.0 & - & 0 & 0\end{array}$

3rd-6th Floor, East Zone

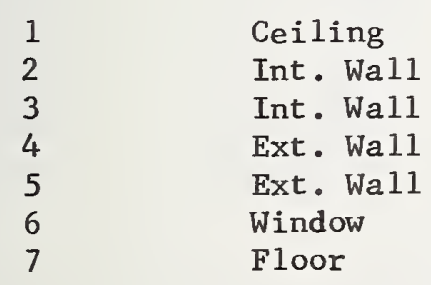

$\begin{array}{rl}1,980.0 & - \\ 275.6 & \text { SW } \\ 1,339.0 & \text { W } \\ 510.0 & \mathrm{~N} \\ 1,659.0 & \mathrm{E} \\ 70.0 & \mathrm{E} \\ 1,980.0 & -\end{array}$

0
0
0
0
0
0.56
0

3rd-6th Floor, Center Zone

$\begin{array}{llllll}1 & \text { Ceiling } & 6,300.0 & - & 0 & 0 \\ 2 & \text { Int. Wall } & 1,079.0 & \mathrm{~S} & 0 & 0 \\ 3 & \text { Int. Wall } & 1,339.0 & \mathrm{~W} & 0 & 0 \\ 4 & \text { Int. Wall } & 1,079.0 & \mathrm{~N} & 0 & 0 \\ 5 & \text { Int. Wa11 } & 1,339.0 & \mathrm{E} & 0 & 0 \\ 6 & \text { Floor } & 6,300.0 & - & 0 & 0\end{array}$


Table 7 - Continued

Surface

Type

Area

Shading

Orientation

Coefficient

Top Floor, South Zone

$\begin{array}{llrlll}1 & \text { Roof } & 1,259.0 & - & 0 & 0.9 \\ 2 & \text { Ext. Wall } & 1,231.0 & \mathrm{~S} & 0 & 0.9 \\ 3 & \text { Window } & 49.0 & \mathrm{~S} & 0.56 & 0 \\ 4 & \text { Int. Wall } & 275.6 & \mathrm{NW} & 0 & 0 \\ 5 & \text { Int. Wall } & 890.0 & \mathrm{~N} & 0 & 0 \\ 6 & \text { Int. Wall } & 275.6 & \mathrm{NE} & 0 & 0 \\ 7 & \text { Floor } & 1,259.0 & - & 0 & 0\end{array}$

Top Floor, West Zone

1
2
3
4
5
6
7

Roof
Int. Wall
Ext. Wall
Window
Ext. Wall
Int. Wall
Floor

$1,807.0$

275.6

$1,490.0$

70.0

340.0

$1,170.0$

$1,807.0$

0
0
0
0.56
0
0
0

0.9

0

0.9

0

0.9

0

0

Top Floor, East Zone

$\begin{array}{llrlll}1 & \text { Roof } & 1,807.0 & - & 0 & 0.9 \\ 2 & \text { Int. Wall } & 275.6 & \text { SW } & 0 & 0 \\ 3 & \text { Int. Wall } & 1,170.0 & \text { W } & 0 & 0 \\ 4 & \text { Ext. Wall } & 340.0 & \mathrm{~N} & 0 & 0.9 \\ 5 & \text { Ext. Wall } & 1,490.0 & \mathrm{E} & 0 & 0.9 \\ 6 & \text { Window } & 70.0 & \mathrm{E} & 0.56 & 0 \\ 7 & \text { Floor } & 1,807.0 & - & 0 & 0\end{array}$

Top Floor, Center Zone

$\begin{array}{rrrrrr}1 & \text { Int. Wall } & 5,100.0 & - & 0 & 0 \\ 2 & \text { Int. Wal1 } & 890.0 & \mathrm{~S} & 0 & 0 \\ 3 & \text { Int. Wall } & 1,170.0 & \mathrm{~W} & 0 & 0 \\ 4 & \text { Int. Wall } & 890.0 & \mathrm{~N} & 0 & 0 \\ 5 & \text { Int. Wall } & 1,170.0 & \mathrm{E} & 0 & 0 \\ 6 & \text { Floor } & 5,100.0 & - & 0 & 0\end{array}$

$1 \mathrm{ft}^{2}=0.0929 \mathrm{~m}^{2}$ 
Table 7 - Continued

\begin{tabular}{|c|c|c|c|c|c|}
\hline e & Type & $\begin{array}{l}\text { Area } \\
\mathrm{ft}^{2}\end{array}$ & Orientation & $\begin{array}{c}\text { Shading } \\
\text { Coefficient }\end{array}$ & $\begin{array}{l}\text { Absorption } \\
\text { Coefficient }\end{array}$ \\
\hline
\end{tabular}

Second Floor, South Zone

$\begin{array}{llrlll}1 & \text { Ceiling } & 1,259.0 & - & 0 & 0 \\ 2 & \text { Ext. Wall } & 1,068.0 & \mathrm{~S} & 0 & 0.9 \\ 3 & \text { Window } & 232.0 & \mathrm{~S} & 0.56 & 0 \\ 4 & \text { Int. Wall } & 275.6 & \mathrm{NW} & 0 & 0 \\ 5 & \text { Int. Wall } & 910.0 & \mathrm{~N} & 0 & 0 \\ 6 & \text { Int. Wall } & 275.6 & \mathrm{NE} & 0 & 0 \\ 7 & \text { Floor } & 1,259.0 & - & 0 & 0\end{array}$

Second Floor, West Zone

$\begin{array}{llrlll}1 & \text { Ceiling } & 1,807.0 & - & 0 & 0 \\ 2 & \text { Int. Wa11 } & 275.6 & \text { SE } & 0 & 0 \\ 3 & \text { Ext. Wa11 } & 1,216.0 & \text { W } & 0 & 0.9 \\ 4 & \text { Window } & 344.0 & \text { W } & 0.56 & 0 \\ 5 & \text { Ext. Wa11 } & 340.0 & \text { N } & 0 & 0.9 \\ 6 & \text { Int. Wa11 } & 1,170.0 & \text { E } & 0 & 0 \\ 7 & \text { Floor } & 1,807.0 & - & 0 & 0\end{array}$

Second Floor, East Zone

$\begin{array}{llrlll}1 & \text { Ceiling } & 1,807.0 & - & 0 & 0 \\ 2 & \text { Int. Wal1 } & 275.6 & \text { SW } & 0 & 0 \\ 3 & \text { Int. Wa11 } & 1,170.0 & \text { W } & 0 & 0 \\ 4 & \text { Ext. Wa11 } & 340.0 & \text { N } & 0 & 0.9 \\ 5 & \text { Ext. Wa11 } & 1,216.0 & \text { E } & 0 & 0.9 \\ 6 & \text { Window } & 344.0 & \text { E } & 0.56 & 0 \\ 7 & \text { Floor } & 1,807.0 & - & 0 & 0\end{array}$

Second Floor, Center Zone

1
2
3
4
5
6

$$
\begin{aligned}
& \text { Ceiling } \\
& \text { Int. Wa } 11 \\
& \text { Int. Wa11 } \\
& \text { Int. Wa11 } \\
& \text { Int. Wa } 11 \\
& \text { Floor }
\end{aligned}
$$

$5,100.0$

910.0

$1,170.0$

910.0

$1,170.0$

$5,100.0$

-
S
W
N
E
-

0

0

0

0

0 
Table 8 Design Calculation Results for the Final Building Design

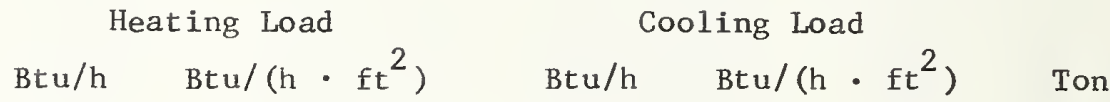

Floor

Area $\mathrm{ft}^{2}$

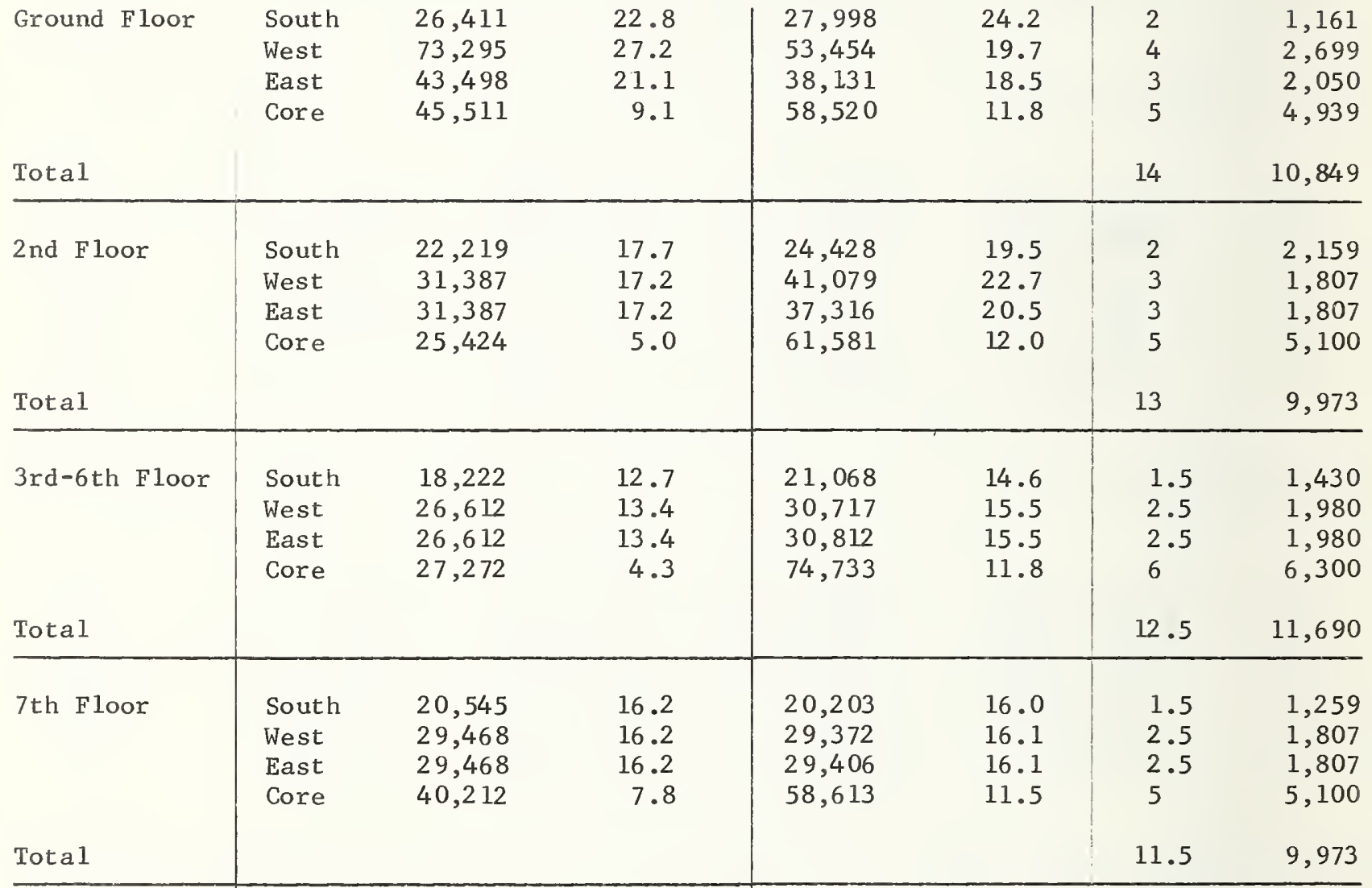

$1 \mathrm{Btu} / \mathrm{h}=0.2929 \mathrm{~W}$

$1 \mathrm{Btu} /\left(\mathrm{h} \cdot \mathrm{ft}^{2}\right)=3.152 \mathrm{~W} / \mathrm{m}^{2}$

1 Ton $=3,516.8 \mathrm{~W}$

$1 \mathrm{ft}^{2}=0.0929 \mathrm{~m}^{2}$ 


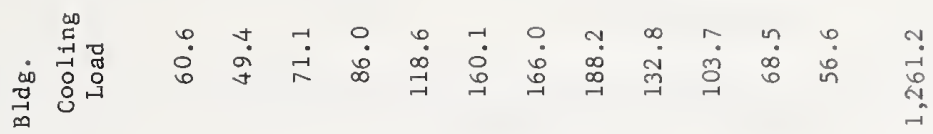

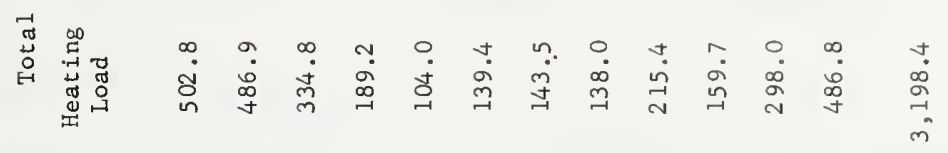

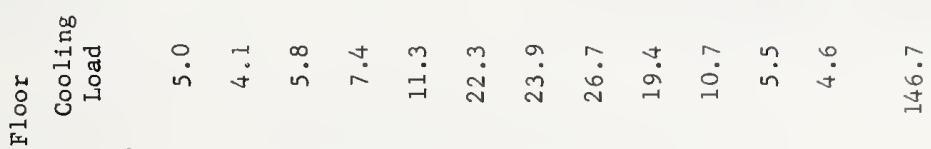

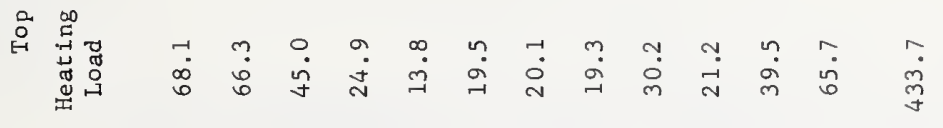

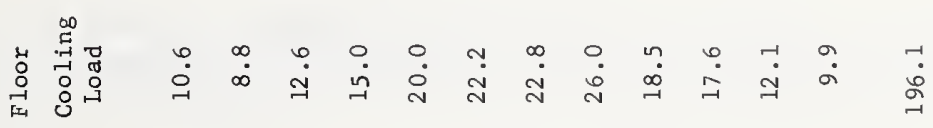

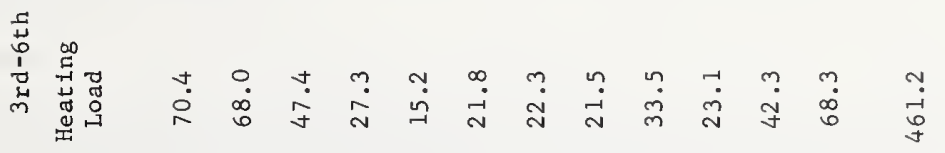

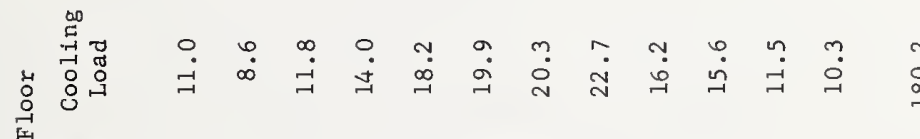

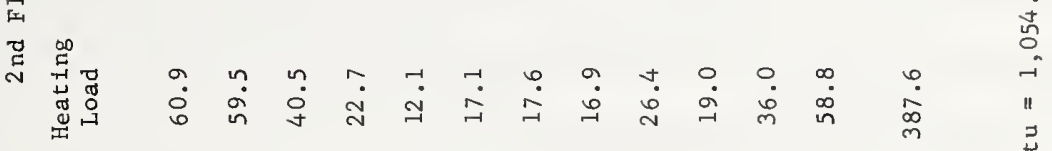

离

a

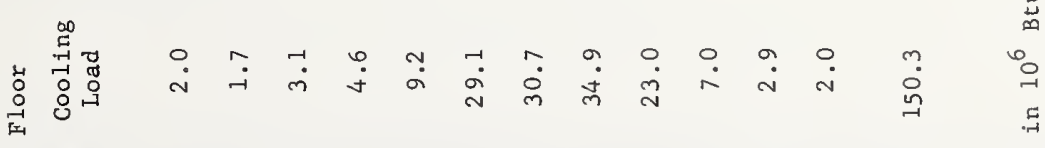

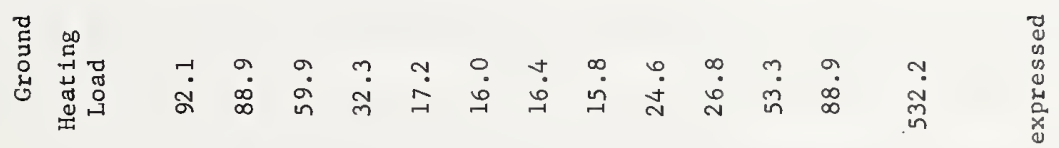

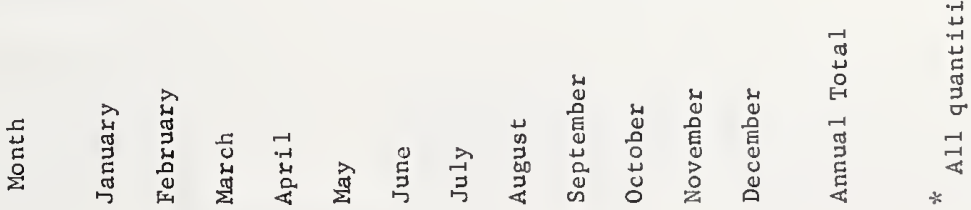


NBS-114A (REV. 7-73)

\begin{tabular}{|c|c|c|c|c|}
\hline $\begin{array}{l}\text { U.S. DEPT. OF COMM. } \\
\text { BIBLIOGRAPHIC DATA } \\
\text { SHEET }\end{array}$ & $\begin{array}{l}\text { 1. PUBLICATION OR REPORT NO. } \\
\text { NBS-BSS } 78\end{array}$ & $\begin{array}{l}\text { 2. Gov't Accession } \\
\text { No. }\end{array}$ & \multicolumn{2}{|c|}{ 3. Recipient's Accession No. } \\
\hline \multirow{2}{*}{\multicolumn{3}{|c|}{$\begin{array}{l}\text { 4. TITLE AND SUBTITLE } \\
\text { Pre-Design Analysis of Energy Conservation Options for a } \\
\text { Multi-Story Demonstration Office Building }\end{array}$}} & \multicolumn{2}{|c|}{$\begin{array}{l}\text { 5. Publication Date } \\
\text { November } 1975\end{array}$} \\
\hline & & & \multicolumn{2}{|c|}{ 6. Performing Organization Code } \\
\hline \multicolumn{3}{|c|}{$\begin{array}{l}\text { 7. AUTHOR(S) } \\
\text { T. Kusuda, J.E. Hill, S. T. Liu, J.P. Barne }\end{array}$} & \\
\hline \multirow{2}{*}{\multicolumn{3}{|c|}{$\begin{array}{l}\text { 9. PERFORMING ORGANIZATION NAME AND ADDRESS } \\
\text { NATIONAL BUREAU OF STANDARDS } \\
\text { DEPARTMENT OF COMMERCE } \\
\text { WASHINGTON, D.C. } 20234\end{array}$}} & \multicolumn{2}{|c|}{$\begin{array}{l}\text { 10. Project/Task/Work Unit No. } \\
4626404\end{array}$} \\
\hline & & & \multicolumn{2}{|c|}{ 11. Contract/Grant No. } \\
\hline \multicolumn{3}{|c|}{$\begin{array}{l}\text { 12. Sponsoring Organization Name and Complete Address (Street, City } \\
\qquad \begin{array}{l}\text { General Services Administration } \\
\text { 18th \& F Streets, N.W。 } \\
\text { Washington, D.C. } 20405\end{array}\end{array}$} & \multicolumn{2}{|c|}{$\begin{array}{l}\text { 13. Type of Report \& Period } \\
\text { Covered } \\
\text { Interim Report }\end{array}$} \\
\hline \multicolumn{5}{|c|}{$\begin{array}{l}\text { 15. SUPPLEMENTARY NOTES } \\
\qquad \begin{array}{l}\text { Library of Congress Catalog Card Nunber: } \quad 75 \div 619306\end{array}\end{array}$} \\
\hline \multicolumn{5}{|c|}{$\begin{array}{l}\text { The design phase of the GSA-Manchester Building included extensive analysis } \\
\text { of the building design and operation to determine the potential for energy conser- } \\
\text { vation. Described in this report are highlights and a summary of the calculations } \\
\text { performed during the design phase. The analysis included a study of the exterior } \\
\text { shell, ventilation rate, lighting and occupancy levels, room temperature controls, } \\
\text { and nighttime flushing of the building using outdoor air, on the predicted yearly } \\
\text { energy consumption of the building. }\end{array}$} \\
\hline \multicolumn{5}{|c|}{$\begin{array}{l}\text { 17. KEY WORDS (six to twelve entries; alphabetical order; capitalize only the first letter of the first key word unless a proper } \\
\text { name; separated by semicolons) } \\
\text { Building design; building energy analysis; energy conservation options; heating } \\
\text { and cooling load calculation; energy design optimization. }\end{array}$} \\
\hline \multirow{2}{*}{\multicolumn{2}{|c|}{ 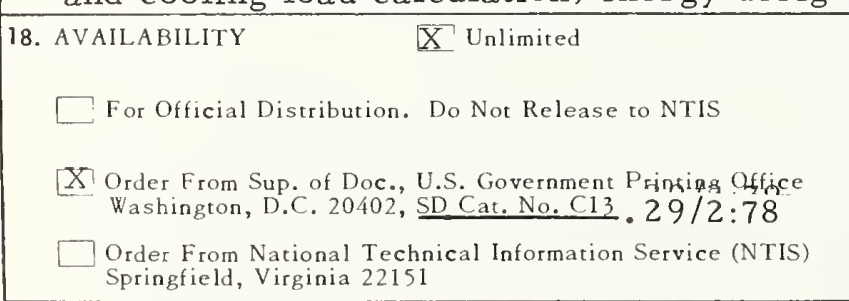 }} & \multicolumn{2}{|c|}{$\begin{array}{l}\text { 19. SECURITY CLASS } \\
\text { (THIS REPORT) } \\
\text { UNCL ASSIFIED }\end{array}$} & 21. NO. OF PAGES \\
\hline & & \multicolumn{2}{|c|}{$\begin{array}{l}\text { 20. SECURITY CLASS } \\
\text { (THIS PAGE) } \\
\text { UNCLASSIFIED }\end{array}$} & \begin{tabular}{|l|} 
22. Price \\
\\
$>1.25$
\end{tabular} \\
\hline
\end{tabular}




\section{Announcement of New Publications in Building Science Series}

Superintendent of Documents, U.S. Government Printing Office, Washington, D.C. 20402

Dear Sir:

Please add my name to the announcement list of new publications to be issued in the series: National Bureau of Standards Building Science Series.

Name

Company

Address

City State Zip Codo

(Notffication key N-839) 
. 




\section{PERIODICALS}

JOURNAL OF RESEARCH reports National Bureau of Standards research and development in physics, mathematics, and chemistry. It is published in two sections, available separately:

- Physics and Chemistry (Section A)

Papers of interest primarily to scientists working in these fields. This section covers a broad range of physical and chemical research, with major emphasis on standards of physical measurement, fundamental constants, and properties of matter. Issued six times a year. Annual subscription: Domestic, $\$ 17.00$; Foreign, $\$ 21.25$.

- Mathematical Sciences (Section B)

Studies and compilations designed mainly for the mathematician and theoretical physicist. Topics in mathematical statistics, theory of experiment design, numerical analysis, theoretical physics and chemistry, logical design and programming of computers and computer systems. Short numerical tables. Issued quarterly. Annual subscription: Domestic, $\$ 9.00$; Foreign, $\$ 11.25$.

DIMENSIONS/NBS (formerly Technical News Bulletin)-This monthly magazine is published to inform scientists, engineers, businessmen, industry, teachers, students, and consumers of the latest advances in science and technology, with primary emphasis on the work at NBS. The magazine highlights and reviews such issues as energy research, fire protection, building technology, metric conversion, pollution abatement, health and safety, and consumer product performance. In addition, it reports the results of Bureau programs in measurement standards and techniques, properties of matter and materials, engineering standards and services, instrumentation, and automatic data processing.

Annual subscription: Domestic, $\$ 9.45$; Foreign, $\$ 11.85$.

\section{NONPERIODICALS}

Monographs-Major contributions to the technical literature on various subjects related to the Bureau's scientific and technical activities.

Handbooks--Recommended codes of engineering and industrial practice (including safety codes) developed in cooperation with interested industries, professional organizations, and regulatory bodies.

Special Publications-Include proceedings of conferences sponsored by NBS, NBS annual reports, and other speciai publications appropriate to this grouping such as wall charts, pocket cards, and bibliographies.

Applied Mathematics Series-Mathematical tables, manuals, and studies of special interest to physicists, engineers, chemists, biologists, mathematicians, computer programmers, and others engaged in scientific and technical work.

National Standard Reference Data Series-Provides quantitative data on the physical and chemical properties of materials, compiled from the world's literature and critically evaluated. Developed under a world-wide' program coordinated by NBS. Program under authority of National Standard Data Act (Public Law 90-396).

NOTE: At present the principal publication outlet for these data is the Journal of Physical and Chemical Reference Data (JPCRD) published quarterly for NBS by the American Chemical Society (ACS) and the American Institute of Physics (AIP). Subscriptions, reprints, and supplements available from ACS, 1155 Sixteenth St. N. W., Wash. D. C. 20056.

Building Science Series-Disseminates technical information developed at the Bureau on building materials, components, systems, and whole structures. The series presents research results, test methods, and performance criteria related to the structural and environmental functions and the durability and safety characteristics of building elements and systems.

Technical Notes-Studies or reports which are complete in themselves but restrictive in their treatment of a subject. Analogous 'to monographs but not so comprehensive in scope or definitive in treatment of the subject area. Often serve as a vehicle for final reports of work petformed at NBS under the sponsorship of other government agencies.

Voluntary Product Standards-Developed under procedures published by the Department of Commerce in Part 10, Title 15, of the Code of Federal Regulations. The purpose of the standards is to establish nationally recognized requirements for products, and to provide all concerned interests with a basis for common understanding of the characteristics of the products. NBS administers this program as a supplement to the activities of the private sector standardizing organizations.

Federal Information Processing Standards Publicatiqns (FIPS PUBS)-Publications in this series collectively constitute the Federal Information Processing Standards Register. Register serves as the official source of information in the Federal Government regarding standards issued by NBS pursuant to the Federal Property and Administrative Services Act of 1949 as amended, Public Law 89-306 (79 Stat. 1127), and as implemented by Executive Order 11717 (38 FR 12315, dated May 11, 1973) and Part 6 of Title 15 CFR (Code of Federal Regulations).

Consumer Information Series-Practical information, based on NBS research and experience, covering areas of interest to the consumer. Easily understandable language and illustrations provide useful background knowledge for shopping in today's technological marketplace.

NBS Interagency Reports (NBSIR)-A special series of interim or final reports on work performed by NBS for outside sponsors (both government and non-government). In general, initial distribution is handled by the sponsor; public distribution is by the National Technical Information Service (Springfield, Va. 22161) in paper copy or microfiche form.

Order NBS publications (except NBSIR's and Bibliographic Subscription Services) from: Superintendent of Documents, Government Printing Office, Washington, D.C. 20402 .

\section{BIBLIOGRAPHIC SUBSCRIPTION SERVICES}

The following current-awareness and literature-survey bibliographies are issued periodically by the Bureau:

Cryogenic Data Center Current Awareness Service

A literature survey issued biweekly. Annual subscription: Domestic, $\$ 20.00$; foreign, $\$ 25.00$.

liquefied Natural Gas. A literature survey issued quarterly. Annual subsciption: $\$ 20.00$.

Superconducting Devices and Materials. A literature survey issued quarterly. Annual subscription: $\$ 20.00$. Send subscription orders and remittances for the preceding bibliographic services to National Technical Information Service, Springfield, Va. 22161.

Electromagnetic Metrology Current Awareness Service Issued monthly. Annual subscription: $\$ 100.00$ (Special rates for multi-subscriptions). Send subscription order and remittance to Electromagnetics Division, National Bureau of Standards, Boulder, Colo. 80302. 
U.S. DEPARTMENT OF COMMERCE

Macional Bureau of Standards

Washington, O.C. 20234

OFFICIAL BUSINESS

Penalty for Private Use, \$300
POSTAGE ANO FEES DAIO US. OEPARTMENT OF COMMEACE $C O M-215$

SPECIAL FOURTH.CLASS RATE BOOK

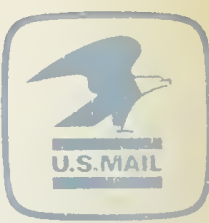

